\title{
Genome-wide association study of open field behavior in outbred heterogeneous stock rats identifies multiple loci implicated in psychiatric disorders
}

\author{
Mustafa Hakan Gunturkun ${ }^{1}$, Tengfei Wang ${ }^{1}$, Apurva S. Chitre ${ }^{2}$, \\ Angel Garcia Martinez ${ }^{1}$, Katie Holl ${ }^{3}$, Celine St. Pierre ${ }^{2}$, Hannah \\ Bimschleger $^{2}$, Jianjun Gao ${ }^{2}$, Riyan Cheng ${ }^{2}$, Oksana Polesskaya ${ }^{2}$, \\ Leah C. Solberg-Woods ${ }^{3}$, Abraham A. Palmer ${ }^{2,4}$ and Hao Chen ${ }^{1 *}$ \\ ${ }^{1}$ Department of Pharmacology, Addiction Science and Toxicology, \\ University of Tennessee Health Science Center, Memphis, TN, USA \\ ${ }^{2}$ Department of Psychiatry, University of California San Diego, La \\ Jolla, CA, USA
}

3 Wake Forest School of Medicine, Department of Internal Medicine, Winston Salem, NC, USA

${ }^{4}$ Institute for Genomic Medicine, University of California San Diego, La Jolla, CA, USA

${ }^{*}$ Corresponding Author (e-mail:hchen@uthsc.edu)

\begin{abstract}
Many personality traits are influenced by genetic factors. Rodents models provide an efficient system for analyzing genetic contribution to these traits. Using 1,246 adolescent heterogeneous stock (HS) male and female rats, we conducted a genome-wide association study (GWAS) of behaviors measured in an open field, including locomotion, novel object interaction, and social interaction. We identified 30 genome-wide significant quantitative trait loci (QTL). Using multiple criteria, including the presence of high impact genomic variants and co-localization of cis-eQTL,
\end{abstract}


we identified 13 candidate genes (Adarb2, Ankrd26, Cacna1c, Clock, Crhr1, Ctu2, Cyp26b1, Eva1a, Fam114a1, Kcnj9, Mlf2, Rab27b, Sec11a) for these traits. Most of these genes have been implicated by human GWAS of various psychiatric traits. For example, Cacna1c, a gene known to be critical for social behavior in rodents and implicated in human schizophrenia and bipolar disorder, is a candidate gene for distance to the social zone. In addition, the QTL region for total distance to the novel object zone, on Chr1 at $144 \mathrm{Mb}$, is syntenic to a hotspot on human Chr15 (82.5-90.8 $\mathrm{Mb}$ ) that contains 14 genes associated with psychiatric or substance abuse traits. Although some of the genes identified by this study appear to replicate findings from prior human GWAS, others likely represent novel findings that can be the catalyst for future molecular and genetic insights into human psychiatric diseases. Together, these findings provide strong support for the use of the HS population to study psychiatric disorders.

Keywords: GWAS, outbred, anxiety, open field, novelty-seeking, social interaction, heterogeneous stock, rats

\section{Introduction}

Many personality traits are predictors of vulnerability to addiction [1]. For example, individuals with symptoms of anxiety are more likely to be smokers $[2,3]$, and novelty seeking is positively correlated with both smoking onset [4] and cocaine abuse [5]. In addition, the social environment plays a critical role in the development and treatment of addiction [6]. Many of these phenomena can be modeled using rodents to unveil their neural, genetic, and molecular mechanisms $[7,8,9,10]$.

The open-field test (OFT) is a widely used behavioral test for measuring anxietylike and exploratory behavior in rodents $[11,12,13,14]$. A rodent is typically placed in an open chamber surrounded by tall walls. Video recording of the rodent's locomotor movements is then analyzed. In general, rats spend most of the testing session walking along the wall (i.e. thigmotaxis). Increased time spent in the center of the area or decreased latency to enter the center are interpreted as indications of lower anxiety. The OFT is widely used to model anxiety and is sensitive to the anxiolytic-like effects of classical benzodiazepines, and 5-HT1A receptor agonists [11]. The novel object interaction test (NOIT) is usually conducted in an open arena where a novel object is placed in the center. The 
time spent and distance traveled around the object zone are used as indicators of preference for novelty. Novel object interaction has been considered as an important predictor in addiction-like traits $[15,16]$ and high novelty preference increases the propensity for addictive drug-seeking behavior $[17,18,9]$. There are multiple different methods for conducting social interaction test (SIT) in rats $[19,20,21]$. In general, an unfamiliar stimulus rat and the rats to be tested are placed in the same arena. While manual scoring of social interaction often allows both rats to be freely moving, experiments using automated video analysis often limit the movement of the stimulus rat and calculate the time spend and distance traveled by the test rat around the stimulus rat.

The heterogeneous stock (HS) rats were originally derived from interbreeding eight inbred strains [22] and have been maintained as outbred for more than 90 generations. HS rats have been successfully used in several high-resolution genome-wide association studies (GWAS) [23, 24, 25, 26]. Here we report the results on associations of genomic loci with measures obtained from OFT, NOIT and SIT. These analyses were based on an expanded data set that contained about twice the sample size of that reported previously [27]. These data were collected as part of a larger GWAS on socially acquired nicotine intravenous self-administration, which will be the subject of a separate publication.

\section{Materials and Methods}

\subsection{Animals}

The N/NIH heterogeneous stock (HS) rat (RRID:RGD2314009), was created at the NIH in 1984 by interbreeding the following eight inbred founder strains: $\mathrm{ACI} / \mathrm{N}, \mathrm{BN} / \mathrm{SsN}, \mathrm{BUF} / \mathrm{N}, \mathrm{F} 344 / \mathrm{N}, \mathrm{M} 520 / \mathrm{N}, \mathrm{MR} / \mathrm{N}, \mathrm{WKY} / \mathrm{N}$ and WN/N [22]. The HS rats used in this study were sent from The Medical College of Wisconsin to the University of Tennessee Health Science Center (UTHSC) at 3-6 weeks of age. A total of 16 batches of HS rats were transferred between October 27, 2014 and September 20, 2018. Each batch consisted of 25 males and 25 females that were used as breeders. After a two-week quarantine period, rats were transferred to a reversed $12 \mathrm{~h}$ light-dark cycle (lights off at 9:00 AM) housing room. Breeding pairs were assigned according to an algorithm that maximized the genetic diversity of the offspring. Litters were culled to a maximum of 8 pups to ensure a consistent nutritional environment. Rats were weaned on 
PND 21. An RFID was inserted subcutaneously when rats were weaned. Two male and two female rats per litter were used for behavioral studies. Teklad Irradiated LM-485 Mouse/Rat Diet and water were provided ad libitum. All rats were group-housed with 2-4 same-sex peers throughout the experiments to avoid social isolation. All procedures were conducted in accordance with the NIH Guidelines concerning the Care and Use of Laboratory Animals, as approved by the Institutional Animal Care and Use Committee of the University of Tennessee Health Science Center.

\subsection{Study Design}

All HS rats (626 males and 620 females in total from 16 batches) were adolescents when tests began. Their age was $31.8 \pm 2.6$ (mean \pm STD) on the day of the OFT. Each HS rat was tested in all three behavioral tests, one test per day, in the following sequence: OFT, NOIT, and SIT. All tests were conducted in the dark phase of the light cycle (9 AM - 4 PM) and were conducted in the same open field and recorded using the same video capture system.

\subsection{Behavioral testing procedure}

\subsubsection{Open field test}

Two OFT arenas were constructed using black acrylic glass, measuring $100 \mathrm{~cm}(L) \times$ $100 \mathrm{~cm}(W) \times 50 \mathrm{~cm}(H)$, which were placed side by side. The floors were covered by wood boards painted with either black or white acrylic paint (ART-Alternatives, ASTM D-4236, Emeryville, CA, USA) to contrast the coat of the animals (i.e. a black board was used for rats with white fur). The test chambers were illuminated by a long-range, 850-nm infrared light (LIR850-70, LDP LLC, Carlstadt, NJ) located $160 \mathrm{~cm}$ above the center of the two test chambers. No source of visible light was present during behavioral testing, with the exception of a flat panel monitor (Dell 1908FP). A digital camera (Panasonic WV-BP334) fitted with an $830 \mathrm{~nm}$ infrared filter (X-Nite830-M37, LTP LLC, Carlstadt, NJ) and located next to the infrared light source was used to record the behavior of the rats. All rats were released at the same corner of the test chamber, and data were collected for $1 \mathrm{~h}$. 


\subsubsection{Novel object interaction test}

This test was conducted the day after the OFT in the same arena. A cylindrical rat cage constructed using 24 aluminum rods $(30 \mathrm{~cm}$ in length) spaced $1.7 \mathrm{~cm}$ apart was used as the novel object. The bottom and top of the cage $(15 \mathrm{~cm}$ in diameter) were manufactured using a 3D printer from polylactic acid. The design can be downloaded from https://github.com/chen42/RatSocialInteractionTest. The novel object was placed in the center of the arena before testing. The test duration was 20 min and was recorded using the same camera as that used in the OFT.

\subsubsection{Social interaction test}

This test was conducted the day after the NOIT. This test compares the preference of a subject rat for a stimulus rat restricted in a cylindrical cage (i.e. the novel object used in the NOIT) against an empty cylindrical cage. The test arena was reduced to $100 \mathrm{~cm}(L) \times 60 \mathrm{~cm}(W) \times 50 \mathrm{~cm}(H)$ by using a black board placed vertically in the arena. Two cylindrical cages described above were placed $\sim 30 \mathrm{~cm}$ away from the walls on opposite sides (i.e., similar to the arrangement commonly used in the three-chamber test). A randomly selected stimulus Sprague-Dawley rat of the same sex and similar weight as the HS test rat was placed into one of the cylindrical cages (kept the same throughout the experiment) $5 \mathrm{~min}$ before the HS subject rat was placed into the arena. The stimulus and subject rats were never housed together and thus were unfamiliar to each other. No social isolation was conducted on either rat. Each stimulus rat was used no more than once per day. The test duration was 20 min and was recorded using the same camera as that used in the OFT.

\subsubsection{Analysis of video data}

Ethovision XT video tracking system (Version 4.0, Noldus Information Technology, The Netherlands) was used to analyze the videos recorded in all behavioral tests. After identifying the arena and calibrating the size of the arena, specific zones in the arena were outlined. For OFT and NOIT, one center zone, which was a circular region with a diameter of $20 \mathrm{~cm}$, was used. For the SIT, one object zone and one social zone, both were circular regions with diameters of 20 $\mathrm{cm}$, corresponding to the two cylindrical cages respectively, were specified. The extracted data included the total distance traveled in the arena, the duration 
and the frequency the test rat was present in specific zones, the distance of the subject to the zones, and the latency of the test rat entering the zones. The center of the subject rat was used for all calculations. Phenotypic correlations were determined using the Pearson test.

\subsection{Pre-processing of phenotype data}

For genetic analysis, each trait was quantile-normalized separately for males and females; this approach is similar to using sex as a covariate. Other relevant covariates (including age, batch number, and dissector) were identified for each trait, and covariate effects were regressed out if they were significant and if they explained more than $2 \%$ of the variance. Residuals were then quantile-normalized again, after which the data for each sex were pooled prior to further analysis. This approach removed mean differences due to sex; further, it did not attempt to model gene-by-sex interactions.

\subsection{Genotyping and estimates of heritability}

Genotypes were determined using genotyping-by-sequencing (GBS), as described previously [28]. This produced 3,513,494 SNPs with an estimated error rate $<1 \%$. Variants for $\mathrm{X}$ - and Y-chromosomes were not called. We used this set of SNPs for GWAS, genetic correlations, and heritability estimates. We used GCTA-GREML [29] analysis to estimate proportion of variance attributable to SNPs.

\subsection{Genetic Mapping}

GWAS analysis employed a linear mixed model, as implemented in the software GCTA [30], using a genetic relatedness matrix (GRM) to account for the complex family relationships within the HS population and the Leave One Chromosome Out (LOCO) method to avoid proximal contamination [31, 32]. Significance thresholds were calculated using permutation. Because all traits were quantile normalized, we used the same threshold for all traits [33]. To identify QTLs, we scanned each chromosome to determine if there was at least one SNP that exceeded the permutation-derived threshold of $-\log _{10}(p)>5.6$, which was supported by a second SNP within $0.5 \mathrm{Mb}$ that had a p-value that was within $2-\log _{10}(p)$ units of the index SNP.

Other QTLs on the same chromosome were tested to ensure that they were 
independent of the first. To establish independence, we used the top SNP from the first QTL as a covariate and performed a second GWAS of the chromsome in question. If the resulting GWAS had an additional SNP with a p-value that exceeded our permutation-derived threshold, it was considered to be a second, independent locus. This process was repeated (including all previously significant SNPs as covariates), until no more QTLs were detected on a given chromosome. Linkage disequilibrium (LD) intervals for the identified QTL were determined by identifying those markers that had a high correlation coefficient with the peak marker $\left(r^{2}=0.6\right)$.

\section{Results}

\subsection{Sex differences}

We found that many of the traits measured in OFT, NOIT, and SIT are different between males and females (Table S1). In OFT, with the exception of latency of entering the center zone, all traits have statistically significant sex differences. In addition, four out of six traits in NOIT and seven out of eleven traits in SIT are different between males and females. The range of effect size (Cohen's d) for statistically significant differences is $(0.14,0.31)$. Our genetic analysis quantile-normalized each trait separately for males and females. This approach removed mean differences due to sex and allowed us to combine males and females in the same analysis to increase the power of GWAS,

\subsection{Phenotypic correlations}

We calculated Pearson correlation between the 23 traits (Figure 1). We found 197 correlations with un-adjusted $\mathrm{p}$ values less than 0.05 . Most of these correlations have relatively low Person coefficient (mean is 0.23 , median is 0.18 ). However, due to the large sample size, most of these correlations are highly significant (median $-\log _{10}(p)$ is 7.8 ). In general, correlations of traits obtained from the same behavioral test are among the strongest. For example, frequency of visiting the center and duration of staying in the center are positively correlated in OFT $(\mathrm{r}=0.76)$, and duration in the social zone and distance to the social zone in the SIT are negatively correlated $(\mathrm{r}=-0.76)$. Most of these correlations are expected from the definitions of these variables.

Among the correlations of variables derived from two different behavioral tests, 
correlations for measures of distance traveled are among the highest (range of Pearson r: $0.39-0.47$, e.g. Figure 6 A, B). Distance traveled in the OFT is also correlated with duration of center time in the NOIT (e.g. Figure $6 \mathrm{C}$ ). Interestingly, the frequencies of visiting the center of the area in the NOIT is correlated with the frequency of visiting the social zone in the SIT (Figure 6 D). In contrast, OFT center frequency is negatively correlated with NOIT mean distance to center in NOIT (Figure $6 \mathrm{E}$ ), and distance to object zone in SIT is negatively correlated with center frequency in NOIT (Figure $6 \mathrm{~F}$ ).

\subsection{Heritability}

SNP heritability estimates $\left(h^{2}\right)$ for traits are provided in Table 1. In all the three behavioral tests, total travel distance has the highest heritability. In OFT, all heritability estimates are between $0.28-0.38$, with the exception of that for latency of entering the center zone $\left(h^{2}=0.08\right)$. Heritability estimates for variables from the NOIT are slightly lower than that of the OFT; most of them are in the range of $0.21-0.29$, with the exception of that for the latency of entering the center zone $\left(h^{2}=0.10\right)$. Heritability estimates for various measures of the SIT are in the range of $0.10-0.28$. Interestingly, heritability estimates for measures on the social zone are consistently greater than those for the object zone.

\subsection{Identification of multiple GWAS hits}

In Table 2, we present single nucleotide polymorphisms (SNPs) that are significantly associated with the phenotypes. The genome-wide statistical significance of the association is determined by $-\log _{10} P$ values which ranges from 5.609 to 8.268 . The p-values correspond to these are $2.46 \times 10^{-6}$ and $0.5 \times 10^{-8}$, respectively. For OFT, there are 9 significant loci for 5 traits. We did not find a significant QTL for Duration in center zone $\left(h^{2}=0.284 \pm 0.045\right)$. We identified two loci for Frequency of entering center zone and Total travel distance, 3 loci for Total distance to center zone. We found 4 NOIT traits have significant loci. Among them, Total distance to center zone has 3 loci and Mean distance to center zone has 2 loci. We did not find any significant loci for Frequency of entering center zone $\left(h^{2}=0.209 \pm 0.041\right)$ and Latency of entering center zone $\left(h^{2}=0.100 \pm 0.034\right)$. For SIT, we identified significant loci for all traits except Latency of entering object zone which has heritability of $h^{2}=0.082 \pm 0.032$. We found 2 loci for the traits Latency of entering social zone, Mean distance to social 
zone Total distance to social zone and Total travel distance. All genome-wide significant loci are shown in Figure 2. Genetic mapping of individual traits are shown as Manhattan plots as Supplementary Figures S1-S23. Regional association plots for representative traits are shown in Fig 3 - these traits are shown in Supplementary Figures 3-5 for OIT, NOIT, and SIT, respectively.

\subsection{Pleiotropic loci}

To determine if traits that mapped to the same location are pleiotropic, we considered the minor allele frequency (MAF), and the SDP of the index SNP among the 8 founder strains that were used to create the HS. Using these criteria, we did not observe any pleiotropic loci between the traits analyzed in different tests. However, we did identify pleiotropic loci between the traits of the same behavior test. Most of these traits are highly correlated, as shown in Figure 1. With the exception of three sets of QTL (Table S3), all others share the same top SNP (Table S2).

\subsection{Candidate gene identification}

The number of genes within the identified QTL ranges from 1 to 127 (mean: 30.1, median: 19. Table 2). There is only one region that contains a single gene: Adarb2 within chr17:58Mb for latency of entering social zone in SIT. However, it is also possible that the causal allele is a regulatory variant that is located in this interval but regulates a gene outside of the identified interval.

All other loci contained more than one gene. To identify candidate genes, we combined several criteria: 1) the presence of moderate or high impact variants located within the gene, as predicted by SnpEff [34]. We also require these variants are in high LD with the top SNP. We identified 149 coding variants within 30 QTL, 8 of which were predicted to have a high impact (Supplementary Table S4). 2) the presence of a significant cis-eQTL in one or more of the five brain regions in a dataset containing 88 navie adult HS rats[35], 3) has a human ortholog that has been reported to be associated with psychiatric diseases (including drug abuse). When multiple candidates are present using the above criteria, we remove the gene with very low expression levels across all five regions in the RNA-seq data set (e.g., FPKM < 0.5) and select the candidate with the strongest support for the literature. Combining these criteria with a literature search conducted using GeneCup [36], we identified plausible candidate genes 
within 13 loci (Table 3).

In addition, for total distance to the novel object zone, the QTL region on chr1 (144 Mb, size: 4.1 Mb, Figure S34) contains 69 gene with human orthologs. We found 14 of these genes have been reported in human GWAS to be associated with psychiatric conditions or addiction with genome-wide significance (ACAN, ADAMTSL3, ALPK3, CPEB1, FES, FURIN, LINC00933, MIR9-3HG, MRPL46, NMB, POLG-DT, SEC11A, ZNF592, ZSCAN2, Table S5). Three additional genes with sub-threshold significance in human GWAS are also included. These genes are all located in a syntenic region on human chromosome 15 (82.5-90.8 Mb). Although based on the criteria described above, Sec11a is the best candidate gene (Table 3 ), it is possible that this region contains multiple genes that are associated with the trait.

\section{Discussion}

As part of a GWAS on intravenous nicotine self-administration in adolescent HS rats that we are conducting $[27,37]$, we collected several behavioral phenotypes related to anxiety, novelty exploration, and social interaction. We have previously reported that these behavioral traits contribute to the variation in nicotine intake [27]. We report here GWAS results of three behavioral traits: OFT, NOIT, and SIT, which were all conducted in the same open field. We identified 24 QTL for 30 traits. Using a set criteria outlined above, we identified 13 candidate genes.

OFT, NOIT, and SIT are widely used behavioral assays in rodents. With over 1,200 rats, ours represent some of the largest data collected using these assays. Similar to our interim report on this data set [27], we found a large number of correlations with relatively low coefficients (e.g., $r<0.4$ ) but with high statistical significance. It is likely that these correlated traits are controlled by the same behavioral processes and thus are influenced by the same genetic factors. In fact, our genetic analysis did find several pleiotropic sites (Table S3). Almost all pleiotropic loci are reported for traits measured in the same behavior assay. It is likely that further increasing sample size will provide greater statistical power to detect pleiotropic effect across different behavioral assays.

Many of the candidate genes in this study have been associated with psychiatric or drug abuse traits in humans. For example, we identified Cyp2661, a retinoic acid degrading enzyme, as a candidate gene for the frequency of entering the center 
zone and total distance to the center zone in OFT; both of which are measures of anxiety-like behaviors. Cyp26b1 has been associated with Schizophrenia in several human GWAS [38, 39]. Anxiety symptoms are common in schizophrenia patients [40,41]. Cyp26b1 is is expressed in parvalbumin-positive interneurons [42]. Most interestingly, knockdown Cyp26b1 in the nucleus accumbens shell decreased anxiety-like behavior [43].

The Crhr1 gene, which encodes corticotrophin release hormone receptor 1, is a candidate gene for total travel distance in the OFT. Crhr 1 is involved in anxietylike behavior in OFT in rats $[44,45]$. In mice, conditional knockout approach showed that Crhr1 in the forebrain underlies the effect of early life stress on total travel distance in the OFT [46], which provides a direct confirmation for the association we report here.

Among the candidate genes for NOIT, Eva1a, a candidate gene for the duration in the center zone, is supported by strong cis-eQTL and a missense variant. Eva1a has no literature support and thus could lead to the discovery of new mechanisms for novelty seeking-like behavior. Sec11a, a candidate gene for total distance in the center zone, is associated with depression and schizophrenia [47, 39, 48]. Mlf2, a candidate gene for total distance to center zone in NOIT, is associated with smoking in humans [49] and has very high expression levels in the accumbens (Table 3).

For the SIT, we identified Cacna1c, encoding the $\mathrm{Ca}_{\mathrm{v}} 1.2$ subunit of the L-type $\mathrm{Ca}^{2+}$ channel, as a candidate gene for distance to the social zone. Cacna1c has been associated with schizophrenia [50] and bipolar disorder [51] in human GWAS. Both schizophrenia and bipolar disorders are associated with impairments in a range of social deficits $[52,53]$. In animal studies, Sprague-Dawley rats with heterozygotic deletion of the Cacna1c gene (homozygotic mutation is lethal) showed many deficits in social behavior. These included reduced levels of ultrasonic vocalizations during rough-and-tumble play, as well as social approach behavior elicited by playback of ultrasonic vocalizations $[54,55]$. In mice, a knockdown of Cacna1c in the nucleus accumbens significantly increased susceptibility to social stress [56]. Knocking down of Cacna1c in the prefrontal cortex of adult mice also recapitulated many of the social deficits [57]. Importantly, some of the behavioral effects of Cacna1c appear to interact with genetic background [58].

Among the other candidate genes for the SIT traits, Rab27b is involved in 
the presynaptic mechanism of long-term potentiation [59] as well as myelin biogenesis in oligodendrocytes [60]. Ankrd26 is expressed in the arcuate and ventromedial nuclei and in the ependyma[61]. Kcnj9 is involved in neurite outgrowth [62]. Ctu2 is involved in post-translational modification of tRNAs [63]. Adarb2 has been associated with home cage activity [64] and unipolar depression [65]. The Clock gene is involved in the maintenance of locomotor rhythms [66]. Mutations of the CLOCK gene have been implicated in many psychiatric disorders [67]. Although these candidates are well supported by multiple lines of evidence, additional work is needed to confirm their causal relationship to the corresponding behavioral traits.

The total distance to the novel object zone is associated with chr1:144080083 (allele frequency: $0.91,-\log _{10}(p)=5.969$, size of interval: $4.1 \mathrm{Mb}$, Figure S34). This SNP is also associated with the duration rats stayed in the novel object zone, although the $\mathrm{p}$ value did not reach genome-wide significance $(-\log \mathrm{P}=4.63)$. This region contains 69 known genes. Its syntenic region on human Chr15 (82.5-90.8 $\mathrm{Mb})$ is a hotspot for human pyschiatric diseases, containing 30 SNPs and 14 genes (ACAN, ADAMTSL3, ALPK3, CPEB1, FES, FURIN, LINC00933, MIR93HG, MRPL46, NMB, POLG-DT, SEC11A, ZNF592, ZSCAN2) associated with generalized anxiety disorder, schizophrenia, bipolar disorder, obsessive compulsive disorder, attentions deficit hyperactivity disorder, autism spectrum disorder, and unipolar depression, smoking behavior, etc. These results are reported in 21 publications (Table S5). Using the criteria described above, we identified Sec11a as the best candidate gene (Table 3). However, given the large number of genetic variants reported in human GWAS that are associated with psychiatric conditions within this syntenic region, it is very likely that this region contains multiple genes that are associated with novelty seeking-like behavior.

We include overlapping with human psychiatric GWAS results as part of the criteria in prioritizing candidate genes. It is possible that this approach could introduce bias and prevent us from making novel discoveries. For example, two (Cyp26b1 and Crhr1) of the three candidate genes for OFT have been associated with schizophrenia, rather than anxiety. However, many genetic variants are pleiotropic for multiple psychiatric diseases [68]. For example, polygenic risk scores for schizophrenia have been associated with many other psychiatric diseases, such as anxiety disorder [69] or major depressive disorder [70], or cognitive performance [71]. Together with other evidence, we believe considering human psychiatric GWAS findings when identifying candidate genes 
in our study, even when the behavior trait in rats does not map directly to the psychiatric disease, is still valid and will likely increase the transnational value of our findings.

The presence of cis-eQTL in the brain is one of the strongest pieces of evidence that we use to prioritizes candidate genes. Nine of the 13 candidate genes we identified have cis-eQTL. Two of the strongest candidate genes in our results, Cacna1c for social behavior and Crhr1 for anxiety-like behavior, are both supported by prior studies on similar traits using knockout mice. However, we did not find significant cis-eQTL of these two genes in our dataset. This could imply either our cis-eQTL dataset lack sufficient power or that genetic regulation of the traits does not directly involve gene expression in the brain regions that we have eQTL data. In addition, several QTL regions contain multiple cis-eQTL. It is possible this is due to strong LD within the region.

The HS rat population has already been successfully used in genetic mapping studies of physiological or behavioral traits $[72,73,26]$. Prior study mapped several anxiety-like traits using zero maze [23]. Several GWAS using HS to study behavioral regulation [74], response to cocaine cues [75], cocaine selfadministration [76], nicotine self-administration [37, 27], or oxycodone selfadministration are underway. Our study add to the literature 30 QTLs and 13 candidate genes for psychiatric related behavioral traits. While some of the candidate genes are well supported by knockout studies in mice and human GWAS, others likely represent novel findings that can be the catalyst for future molecular and genetic insights on psychiatric diseases.

\section{Conflict of Interest Statement}

The authors declare that the research was conducted in the absence of any commercial or financial relationships that could be construed as a potential conflict of interest.

\section{Author Contributions}

H.C. and A.A.P. designed the study. T.W. and A.G.M collected the data. A.S.C., O.P. and M.H.G. analyzed the data. The manuscript was written by M.H.G., A.A.P. and H.C. All authors contributed to the article and approved 
the submitted version.

\section{Funding}

This work was supported by the National Institute on Drug Abuse (P50 DA037844).

\section{Acknowledgments}

The authors thank Wenyan Han, Yanyan Lin, and Pawandeep Kaur for their contributions in collecting some of the behavioral data. We thank the GeneNetwork team for hosting the data.

\section{Data Availability Statement}

The datasets generated for this study can be found in GeneNetwork (http://www.genenetwork.org).

\section{References}

[1] S. Hamidullah, HHA. Thorpe, JA. Frie, RD. Mccurdy, and JY. Khokhar. Adolescent substance use and the brain: Behavioral, cognitive and neuroimaging correlates. Front Hum Neurosci, 14:298, 2020. PMCID: PMC7418456, PMID: 32848673.

[2] L. Garey, H. Olofsson, T. Garza, JM. Shepherd, T. Smit, and MJ. Zvolensky. The role of anxiety in smoking onset, severity, and cessation-related outcomes: a review of recent literature. Curr Psychiatry Rep, 22(8):38, 2020. PMID: 32506166 .

[3] RL. DuPont. Anxiety and addiction: a clinical perspective on comorbidity. Bull Menninger Clin, 59(2 Suppl A):53-72, 1995. PMID: 7795572.

[4] M. Laucht, K. Becker, M. El-Faddagh, E. Hohm, and MH. Schmidt. Association of the drd4 exon iii polymorphism with smoking in fifteen-year-olds: a mediating role for novelty seeking? J Am Acad Child Adolesc Psychiatry, 44(5):477-484, 2005. PMID: 15843770.

[5] JJ. Mahoney, DG. Thompson-Lake, K. Cooper, CD. Verrico, TF. Newton, and R. De La Garza. A comparison of impulsivity, depressive symptoms, 
lifetime stress and sensation seeking in healthy controls versus participants with cocaine or methamphetamine use disorders. J Psychopharmacol, 29(1):50-56, 2015. PMID: 25424624.

[6] F. Truan. Addiction as a social construction: a postempirical view. $J$ Psychol, 127(5):489-499, 1993. PMID: 8271227.

[7] JA. Wilking, KG. Hesterberg, VH. Nguyen, AP. Cyboron, AY. Hua, and JA. Stitzel. Comparison of nicotine oral consumption and baseline anxiety measures in adolescent and adult c57bl/6j and c3h/ibg mice. Behav Brain Res, 233(2):280-287, 2012. PMCID: PMC3402682, PMID: 22633961.

[8] AC. Manhães, MC. Guthierrez, CC. Filgueiras, and Y. Abreu-Villaça. Anxiety-like behavior during nicotine withdrawal predict subsequent nicotine consumption in adolescent c57bl/6 mice. Behav Brain Res, 193(2):216-224, 2008. PMID: 18573281.

[9] R. Redolat, A. Pérez-Martínez, MC. Carrasco, and P. Mesa. Individual differences in novelty-seeking and behavioral responses to nicotine: a review of animal studies. Curr Drug Abuse Rev, 2(3):230-242, 2009. PMID: 20443770 .

[10] Y. Pelloux, E. Giorla, C. Montanari, and C. Baunez. Social modulation of drug use and drug addiction. Neuropharmacology, 159:107545, 2019. PMID: 30807753.

[11] L. Prut and C. Belzung. The open field as a paradigm to measure the effects of drugs on anxiety-like behaviors: a review. Eur J Pharmacol, 463(1-3):3-33, 2003. PMID: 12600700.

[12] Ann-Katrin Kraeuter, Paul C Guest, and Zoltán Sarnyai. The open field test for measuring locomotor activity and Anxiety-Like behavior. Methods Mol. Biol., 1916:99-103, 2019.

[13] Natalia Kulesskaya and Vootele Voikar. Assessment of mouse anxiety-like behavior in the light-dark box and open-field arena: role of equipment and procedure. Physiol. Behav., 133:30-38, June 2014.

[14] Michael L Seibenhener and Michael C Wooten. Use of the open field maze to measure locomotor and anxiety-like behavior in mice. J. Vis. Exp., (96):e52434, February 2015. 
[15] Shelly B Flagel, Maria Waselus, Sarah M Clinton, Stanley J Watson, and Huda Akil. Antecedents and consequences of drug abuse in rats selectively bred for high and low response to novelty. Neuropharmacology, $76 \mathrm{Pt}$ B:425-436, January 2014.

[16] M T Bardo, R L Donohew, and N G Harrington. Psychobiology of novelty seeking and drug seeking behavior. Behav. Brain Res., 77(1-2):23-43, May 1996.

[17] David Belin, Nadège Berson, Eric Balado, Pier Vincenzo Piazza, and Véronique Deroche-Gamonet. High-novelty-preference rats are predisposed to compulsive cocaine self-administration. Neuropsychopharmacology, 36(3):569-579, February 2011.

[18] Mary E Cain, Donald A Saucier, and Michael T Bardo. Novelty seeking and drug use: contribution of an animal model. Exp. Clin. Psychopharmacol., 13(4):367-375, November 2005.

[19] Sandra E File and Pallab Seth. A review of 25 years of the social interaction test. Eur. J. Pharmacol., 463(1-3):35-53, February 2003.

[20] Iulia Toth and Inga D Neumann. Animal models of social avoidance and social fear. Cell Tissue Res., 354(1):107-118, October 2013.

[21] SE. File, S. Cheeta, EE. Irvine, S. Tucci, and M. Akthar. Conditioned anxiety to nicotine. Psychopharmacology (Berl), 164(3):309-317, 2002. PMID: 12424555 .

[22] C. Hansen and K. Spuhler. Development of the national institutes of health genetically heterogeneous rat stock. Alcohol Clin Exp Res, 8(5):477-479, 1984. PMID: 6391259.

[23] A. Baud, R. Hermsen, V. Guryev, P. Stridh, D. Graham, MW. McBride, T. Foroud, S. Calderari, M. Diez, J. Ockinger, AD. Beyeen, A. Gillett, N. Abdelmagid, AO. Guerreiro-Cacais, M. Jagodic, J. Tuncel, U. Norin, E. Beattie, N. Huynh, WH. Miller, DL. Koller, I. Alam, S. Falak, M. OsbornePellegrin, E. Martinez-Membrives, T. Canete, G. Blazquez, E. Vicens-Costa, C. Mont-Cardona, S. Diaz-Moran, A. Tobena, O. Hummel, D. Zelenika, K. Saar, G. Patone, A. Bauerfeind, MT. Bihoreau, M. Heinig, YA. Lee, C. Rintisch, H. Schulz, DA. Wheeler, KC. Worley, DM. Muzny, RA. Gibbs, M. Lathrop, N. Lansu, P. Toonen, FP. Ruzius, E. de Bruijn, H. Hauser, DJ. 
Adams, T. Keane, SS. Atanur, TJ. Aitman, P. Flicek, T. Malinauskas, EY. Jones, D. Ekman, R. Lopez-Aumatell, AF. Dominiczak, M. Johannesson, R. Holmdahl, T. Olsson, D. Gauguier, N. Hubner, A. Fernandez-Teruel, E. Cuppen, R. Mott, and J. Flint. Combined sequence-based and genetic mapping analysis of complex traits in outbred rats. Nat Genet, 45(7):767775, 2013. PMCID: PMC3821058, PMID: 23708188.

[24] Leah C Solberg Woods and Abraham A Palmer. Using heterogeneous stocks for Fine-Mapping genetically complex traits. Methods Mol. Biol., 2018:233-247, 2019.

[25] Apurva S Chitre, Oksana Polesskaya, Katie Holl, Jianjun Gao, Riyan Cheng, Hannah Bimschleger, Angel Garcia Martinez, Tony George, Alexander F Gileta, Wenyan Han, Aidan Horvath, Alesa Hughson, Keita Ishiwari, Christopher P King, Alexander Lamparelli, Cassandra L Versaggi, Connor Martin, Celine L St Pierre, Jordan A Tripi, Tengfei Wang, Hao Chen, Shelly B Flagel, Paul Meyer, Jerry Richards, Terry E Robinson, Abraham A Palmer, and Leah C Solberg Woods. Genome-Wide association study in 3,173 outbred rats identifies multiple loci for body weight, adiposity, and fasting glucose. Obesity, 28(10):1964-1973, October 2020.

[26] GR. Keele, JW. Prokop, H. He, K. Holl, J. Littrell, A. Deal, S. Francic, L. Cui, DM. Gatti, KW. Broman, M. Tschannen, SW. Tsaih, M. Zagloul, Y. Kim, B. Baur, J. Fox, M. Robinson, S. Levy, MJ. Flister, R. Mott, W. Valdar, and LC. Solberg Woods. Genetic fine-mapping and identification of candidate genes and variants for adiposity traits in outbred rats. Obesity (Silver Spring), 26(1):213-222, 2018. PMCID: PMC5740008, PMID: 29193816.

[27] T. Wang, W. Han, AS. Chitre, O. Polesskaya, LC. Solberg Woods, AA. Palmer, and H. Chen. Social and anxiety-like behaviors contribute to nicotine self-administration in adolescent outbred rats. Sci Rep, 8(1):18069, 2018. PMCID: PMC6305389, PMID: 30584246.

[28] AF. Gileta, J. Gao, AS. Chitre, HV. Bimschleger, CL. St Pierre, S. Gopalakrishnan, and AA. Palmer. Adapting genotyping-by-sequencing and variant calling for heterogeneous stock rats. G3 (Bethesda), 10(7):2195-2205, 2020. PMCID: PMC7341140, PMID: 32398234.

[29] J. Yang, B. Benyamin, BP. McEvoy, S. Gordon, AK. Henders, DR. Nyholt, 
PA. Madden, AC. Heath, NG. Martin, GW. Montgomery, ME. Goddard, and PM. Visscher. Common snps explain a large proportion of the heritability for human height. Nat Genet, 42(7):565-569, 2010. PMCID: PMC3232052, PMID: 20562875.

[30] J. Yang, SH. Lee, ME. Goddard, and PM. Visscher. Gcta: a tool for genome-wide complex trait analysis. Am J Hum Genet, 88(1):76-82, 2011. PMCID: PMC3014363, PMID: 21167468.

[31] R. Cheng, CC. Parker, M. Abney, and AA. Palmer. Practical considerations regarding the use of genotype and pedigree data to model relatedness in the context of genome-wide association studies. G3 (Bethesda), 3(10):1861-1867, 2013. PMCID: PMC3789811, PMID: 23979941.

[32] NM. Gonzales, J. Seo, AI. Hernandez Cordero, CL. St Pierre, JS. Gregory, MG. Distler, M. Abney, S. Canzar, A. Lionikas, and AA. Palmer. Genome wide association analysis in a mouse advanced intercross line. Nat Commun, 9(1):5162, 2018. PMCID: PMC6279738, PMID: 30514929.

[33] R. Cheng and AA. Palmer. A simulation study of permutation, bootstrap, and gene dropping for assessing statistical significance in the case of unequal relatedness. Genetics, 193(3):1015-1018, 2013. PMCID: PMC3583989, PMID: 23267053.

[34] P. Cingolani, A. Platts, le L. Wang, M. Coon, T. Nguyen, L. Wang, SJ. Land, X. Lu, and DM. Ruden. A program for annotating and predicting the effects of single nucleotide polymorphisms, snpeff: Snps in the genome of drosophila melanogaster strain w1118; iso-2; iso-3. Fly (Austin), 6(2):80-92, 2012. PMCID: PMC3679285, PMID: 22728672.

[35] Daniel Munro, Tengfei Wang, Apurva S. Chitre, Oksana Polesskaya, Laura Saba, Hao Chen, Pejman Mohammadi, and Abraham A. Palmer. Mapping genotype-expression associations in heterogeneous stock rat brains to advance behavioral genetics research. Genetics and Epigenetics Cross-Cutting Research Team (GECCRT) Meeting, 2021.

[36] Mustafa Hakan Gunturkun, Efraim Flashner, Tengfei Wang, Megan K. Mulligan, Robert W. Williams, Pjotr Prins, and Hao Chen. Genecup: mine pubmed for gene relationships using custom ontology and deep learning. bioRxiv, 2021. 
[37] T. Wang, W. Han, B. Wang, Q. Jiang, LC. Solberg-Woods, AA. Palmer, and $\mathrm{H}$. Chen. Propensity for social interaction predicts nicotine-reinforced behaviors in outbred rats. Genes Brain Behav, 13(2):202-212, 2014. PMCID: PMC3934210, PMID: 24289793.

[38] Schizophrenia Working Group of the Psychiatric Genomics Consortium. Biological insights from 108 schizophrenia-associated genetic loci. Nature, 511(7510):421-427, 2014. PMCID: PMC4112379, PMID: 25056061.

[39] FS. Goes, J. McGrath, D. Avramopoulos, P. Wolyniec, M. Pirooznia, I. Ruczinski, G. Nestadt, EE. Kenny, V. Vacic, I. Peters, T. Lencz, A. Darvasi, JG. Mulle, ST. Warren, and AE. Pulver. Genome-wide association study of schizophrenia in ashkenazi jews. Am J Med Genet B Neuropsychiatr Genet, 168(8):649-659, 2015. PMID: 26198764.

[40] H. Temmingh and DJ. Stein. Anxiety in patients with schizophrenia: Epidemiology and management. CNS Drugs, 29(10):819-832, 2015. PMID: 26482261.

[41] FM. Howells, DG. Kingdon, and DS. Baldwin. Current and potential pharmacological and psychosocial interventions for anxiety symptoms and disorders in patients with schizophrenia: structured review. Hum Psychopharmacol, 32(5), 2017. PMID: 28812313.

[42] R. Larsen, A. Proue, EP. Scott, M. Christiansen, and Y. Nakagawa. The thalamus regulates retinoic acid signaling and development of parvalbumin interneurons in postnatal mouse prefrontal cortex. eNeuro, 6(1). PMCID: PMC6385081, PMID: 30868103.

[43] Y. Zhang, EJ. Crofton, TES. Smith, S. Koshy, D. Li, and TA. Green. Manipulation of retinoic acid signaling in the nucleus accumbens shell alters rat emotional behavior. Behav Brain Res, 376:112177, 2019. PMCID: PMC7359447, PMID: 31449909.

[44] J. Zhu, Z. Chen, J. Tian, Z. Meng, M. Ju, G. Wu, and Z. Tian. mir-34b attenuates trauma-induced anxiety-like behavior by targeting crhr1. Int $J$ Mol Med, 40(1):90-9100, 2017. PMCID: PMC5466391, PMID: 28498394.

[45] JM. Fan, X. Wang, K. Hao, Y. Yuan, XQ. Chen, and JZ. Du. Upregulation of pvn crhr1 by gestational intermittent hypoxia selectively triggers a male- 
specific anxiogenic effect in rat offspring. Horm Behav, 63(1):25-31, 2013. PMID: 23164543.

[46] XD. Wang, C. Labermaier, F. Holsboer, W. Wurst, JM. Deussing, MB. Müller, and MV. Schmidt. Early-life stress-induced anxiety-related behavior in adult mice partially requires forebrain corticotropin-releasing hormone receptor 1. Eur J Neurosci, 36(3):2360-2367, 2012. PMID: 22672268.

[47] W. Guo, R. Machado-Vieira, S. Mathew, JW. Murrough, DS. Charney, M. Grunebaum, MA. Oquendo, B. Kadriu, N. Akula, I. Henter, P. Yuan, K. Merikangas, W. Drevets, M. Furey, JJ. Mann, FJ. McMahon, CA. Zarate, and YY. Shugart. Exploratory genome-wide association analysis of response to ketamine and a polygenic analysis of response to scopolamine in depression. Transl Psychiatry, 8(1):280, 2018. PMCID: PMC6294748, PMID: 30552317.

[48] AF. Pardiñas, P. Holmans, AJ. Pocklington, V. Escott-Price, S. Ripke, N. Carrera, SE. Legge, S. Bishop, D. Cameron, ML. Hamshere, J. Han, L. Hubbard, A. Lynham, K. Mantripragada, E. Rees, JH. MacCabe, SA. McCarroll, BT. Baune, G. Breen, EM. Byrne, U. Dannlowski, TC. Eley, C. Hayward, NG. Martin, AM. McIntosh, R. Plomin, DJ. Porteous, NR. Wray, A. Caballero, DH. Geschwind, LM. Huckins, DM. Ruderfer, E. Santiago, P. Sklar, EA. Stahl, H. Won, E. Agerbo, TD. Als, OA. Andreassen, M. Bækvad-Hansen, PB. Mortensen, CB. Pedersen, AD. Børglum, J. Bybjerg-Grauholm, S. Djurovic, N. Durmishi, MG. Pedersen, V. Golimbet, J. Grove, DM. Hougaard, M. Mattheisen, E. Molden, O. Mors, M. Nordentoft, M. Pejovic-Milovancevic, E. Sigurdsson, T. Silagadze, CS. Hansen, K. Stefansson, H. Stefansson, S. Steinberg, S. Tosato, T. Werge, DA. Collier, D. Rujescu, G. Kirov, MJ. Owen, MC. O'Donovan, and JTR. Walters. Common schizophrenia alleles are enriched in mutation-intolerant genes and in regions under strong background selection. Nat Genet, 50(3):381-389, 2018. PMCID: PMC5918692, PMID: 29483656.

[49] M. Liu, Y. Jiang, R. Wedow, Y. Li, DM. Brazel, F. Chen, G. Datta, J. Davila-Velderrain, D. McGuire, C. Tian, X. Zhan, H. Choquet, AR. Docherty, JD. Faul, JR. Foerster, LG. Fritsche, ME. Gabrielsen, SD. Gordon, J. Haessler, JJ. Hottenga, H. Huang, SK. Jang, PR. Jansen, Y. Ling, R. Mägi, N. Matoba, G. McMahon, A. Mulas, V. Orrù, T. Palviainen, A. Pandit, GW. Reginsson, AH. Skogholt, JA. Smith, AE. Taylor, C. Turman, G. Willemsen, 
H. Young, KA. Young, GJM. Zajac, W. Zhao, W. Zhou, G. Bjornsdottir, JD. Boardman, M. Boehnke, DI. Boomsma, C. Chen, F. Cucca, GE. Davies, CB. Eaton, MA. Ehringer, T. Esko, E. Fiorillo, NA. Gillespie, DF. Gudbjartsson, T. Haller, KM. Harris, AC. Heath, JK. Hewitt, IB. Hickie, JE. Hokanson, CJ. Hopfer, DJ. Hunter, WG. Iacono, EO. Johnson, Y. Kamatani, SLR. Kardia, MC. Keller, M. Kellis, C. Kooperberg, P. Kraft, KS. Krauter, M. Laakso, PA. Lind, A. Loukola, SM. Lutz, PAF. Madden, NG. Martin, M. McGue, MB. McQueen, SE. Medland, A. Metspalu, KL. Mohlke, JB. Nielsen, Y. Okada, U. Peters, TJC. Polderman, D. Posthuma, AP. Reiner, JP. Rice, E. Rimm, RJ. Rose, V. Runarsdottir, MC. Stallings, A. Stančáková, H. Stefansson, KK. Thai, HA. Tindle, T. Tyrfingsson, TL. Wall, DR. Weir, C. Weisner, JB. Whitfield, BS. Winsvold, J. Yin, L. Zuccolo, LJ. Bierut, K. Hveem, JJ. Lee, MR. Munafò, NL. Saccone, CJ. Willer, MC. Cornelis, SP. David, DA. Hinds, E. Jorgenson, J. Kaprio, JA. Stitzel, K. Stefansson, TE. Thorgeirsson, G. Abecasis, DJ. Liu, and S. Vrieze. Association studies of up to 1.2 million individuals yield new insights into the genetic etiology of tobacco and alcohol use. Nat Genet, 51(2):237-244, 2019. PMCID: PMC6358542, PMID: 30643251.

[50] YP. Liu, X. Wu, X. Xia, J. Yao, and BJ. Wang. The genome-wide supported cacna1c gene polymorphisms and the risk of schizophrenia: an updated meta-analysis. BMC Med Genet, 21(1):159, 2020. PMCID: PMC7414708, PMID: 32770953.

[51] M. Mosheva, A. Serretti, Y. Stukalin, C. Fabbri, M. Hagin, S. Horev, V. Mantovani, S. Bin, A. Mattiaccio, A. Nivoli, E. Vieta, and D. Popovic. Association between canca1c gene rs1034936 polymorphism and alcohol dependence in bipolar disorder. J Affect Disord, 261:181-186, 2020. PMID: 31634677 .

[52] C. Samamé. Social cognition throughout the three phases of bipolar disorder: a state-of-the-art overview. Psychiatry Res, 210(3):1275-1286, 2013. PMID: 24075306.

[53] MF. Green, WP. Horan, and J. Lee. Social cognition in schizophrenia. Nat Rev Neurosci, 16(10):620-631, 2015. PMID: 26373471.

[54] TM. Kisko, MD. Braun, S. Michels, SH. Witt, M. Rietschel, C. Culmsee, RKW. Schwarting, and M. Wöhr. Cacna1c haploinsufficiency leads to 
pro-social 50-khz ultrasonic communication deficits in rats. Dis Model Mech, 11(6), 2018. PMCID: PMC6031367, PMID: 29739816.

[55] M. Wöhr, TM. Kisko, and RKW. Schwarting. Social behavior and ultrasonic vocalizations in a genetic rat model haploinsufficient for the cross-disorder risk gene cacna1c. Brain Sci, 11(6), 2021. PMCID: PMC8229447, PMID: 34072335 .

[56] CE. Terrillion, TC. Francis, AC. Puche, MK. Lobo, and TD. Gould. Decreased nucleus accumbens expression of psychiatric disorder risk gene cacna1c promotes susceptibility to social stress. Int $J$ Neuropsychopharmacol, 20(5):428-433, 2017. PMCID: PMC5417061, PMID: 28165117.

[57] ZD. Kabir, A. Che, DK. Fischer, RC. Rice, BK. Rizzo, M. Byrne, MJ. Glass, NV. De Marco Garcia, and AM. Rajadhyaksha. Rescue of impaired sociability and anxiety-like behavior in adult cacna1c-deficient mice by pharmacologically targeting eif2alpha. Mol Psychiatry, 22(8):1096-1109, 2017. PMCID: PMC5863913, PMID: 28584287.

[58] LJ. Sittig, P. Carbonetto, KA. Engel, KS. Krauss, CM. Barrios-Camacho, and AA. Palmer. Genetic background limits generalizability of genotypephenotype relationships. Neuron, 91(6):1253-1259, 2016. PMCID: PMC5033712, PMID: 27618673.

[59] ER. Arias-Hervert, N. Xu, M. Njus, GG. Murphy, Y. Hou, JA. Williams, SI. Lentz, SA. Ernst, and EL. Stuenkel. Actions of rab27b-gtpase on mammalian central excitatory synaptic transmission. Physiol Rep, 8(9):e14428, 2020. PMCID: PMC7195558, PMID: 32358861.

[60] YT. Shen, Y. Gu, WF. Su, JF. Zhong, ZH. Jin, XS. Gu, and G. Chen. Rab27b is involved in lysosomal exocytosis and proteolipid protein trafficking in oligodendrocytes. Neurosci Bull, 32(4):331-340, 2016. PMCID: PMC5563785, PMID: 27325508.

[61] TK. Bera, XF. Liu, M. Yamada, O. Gavrilova, E. Mezey, L. Tessarollo, M. Anver, Y. Hahn, B. Lee, and I. Pastan. A model for obesity and gigantism due to disruption of the ankrd26 gene. Proc Natl Acad Sci U S A, 105(1):270-275, 2008. PMCID: PMC2224199, PMID: 18162531.

[62] R. Kleene, C. Cassens, R. Bähring, T. Theis, MF. Xiao, A. Dityatev, C. Schafer-Nielsen, F. Döring, E. Wischmeyer, and M. Schachner. Func- 
tional consequences of the interactions among the neural cell adhesion molecule ncam, the receptor tyrosine kinase trkb, and the inwardly rectifying k+ channel kir3.3. J Biol Chem, 285(37):28968-28979, 2010. PMCID: PMC2937924, PMID: 20610389.

[63] Erratum. Hum Mutat, 42(2):219, 2021. PMID: 33559988.

[64] J. Nicod, RW. Davies, N. Cai, C. Hassett, L. Goodstadt, C. Cosgrove, BK. Yee, V. Lionikaite, RE. McIntyre, CA. Remme, EM. Lodder, JS. Gregory, T. Hough, R. Joynson, H. Phelps, B. Nell, C. Rowe, J. Wood, A. Walling, N. Bopp, A. Bhomra, P. Hernandez-Pliego, J. Callebert, RM. Aspden, NP. Talbot, PA. Robbins, M. Harrison, M. Fray, JM. Launay, YM. Pinto, DA. Blizard, CR. Bezzina, DJ. Adams, P. Franken, T. Weaver, S. Wells, SD. Brown, PK. Potter, P. Klenerman, A. Lionikas, R. Mott, and J. Flint. Genome-wide association of multiple complex traits in outbred mice by ultra-low-coverage sequencing. Nat Genet, 48(8):912-918, 2016. PMCID: PMC4966644, PMID: 27376238.

[65] DM. Howard, MJ. Adams, TK. Clarke, JD. Hafferty, J. Gibson, M. Shirali, JRI. Coleman, SP. Hagenaars, J. Ward, EM. Wigmore, C. Alloza, X. Shen, MC. Barbu, EY. Xu, HC. Whalley, RE. Marioni, DJ. Porteous, G. Davies, IJ. Deary, G. Hemani, K. Berger, H. Teismann, R. Rawal, V. Arolt, BT. Baune, U. Dannlowski, K. Domschke, C. Tian, DA. Hinds, M. Trzaskowski, EM. Byrne, S. Ripke, DJ. Smith, PF. Sullivan, NR. Wray, G. Breen, CM. Lewis, and AM. McIntosh. Genome-wide meta-analysis of depression identifies 102 independent variants and highlights the importance of the prefrontal brain regions. Nat Neurosci, 22(3):343-352, 2019. PMCID: PMC6522363, PMID: 30718901.

[66] NM. Ludin, A. Orts-Sebastian, JF. Cheeseman, J. Chong, AF. Merry, D. Cumin, S. Yamazaki, MDM. Pawley, and GR. Warman. General anaesthesia shifts the murine circadian clock in a time-dependant fashion. Clocks Sleep, 3(1):87-97, 2021. PMCID: PMC7930986, PMID: 33530488.

[67] JB. Schuch, JP. Genro, CR. Bastos, G. Ghisleni, and L. Tovo-Rodrigues. The role of clock gene in psychiatric disorders: Evidence from human and animal research. Am J Med Genet B Neuropsychiatr Genet, 177(2):181-198, 2018. PMID: 28902457.

[68] JW. Smoller, OA. Andreassen, HJ. Edenberg, SV. Faraone, SJ. Glatt, and 
KS. Kendler. Psychiatric genetics and the structure of psychopathology. Mol Psychiatry, 24(3):409-420, 2019. PMCID: PMC6684352, PMID: 29317742.

[69] HJ. Jones, E. Stergiakouli, KE. Tansey, L. Hubbard, J. Heron, M. Cannon, P. Holmans, G. Lewis, DE. Linden, PB. Jones, G. Davey Smith, MC. O’Donovan, MJ. Owen, JT. Walters, and S. Zammit. Phenotypic manifestation of genetic risk for schizophrenia during adolescence in the general population. JAMA Psychiatry, 73(3):221-228, 2016. PMCID: PMC5024747, PMID: 26818099 .

[70] Cross-Disorder Group of the Psychiatric Genomics Consortium. Identification of risk loci with shared effects on five major psychiatric disorders: a genome-wide analysis. Lancet, 381(9875):1371-1379, 2013. PMCID: PMC3714010, PMID: 23453885.

[71] A. Hatzimanolis, P. Bhatnagar, A. Moes, R. Wang, P. Roussos, P. Bitsios, CN. Stefanis, AE. Pulver, DE. Arking, N. Smyrnis, NC. Stefanis, and D. Avramopoulos. Common genetic variation and schizophrenia polygenic risk influence neurocognitive performance in young adulthood. Am J Med Genet B Neuropsychiatr Genet, (5):392-401, 2015. PMCID: PMC5008149, PMID: 25963331.

[72] LC. Solberg Woods and AA. Palmer. Using heterogeneous stocks for finemapping genetically complex traits. Methods Mol Biol, 2018:233-247, 2019. PMID: 31228160.

[73] LC. Woods and R. Mott. Heterogeneous stock populations for analysis of complex traits. Methods Mol Biol, 1488:31-44, 2017. PMCID: PMC5869698, PMID: 27933519 .

[74] CP. King, AA. Palmer, LC. Woods, LW. Hawk, JB. Richards, and PJ. Meyer. Premature responding is associated with approach to a food cue in male and female heterogeneous stock rats. Psychopharmacology (Berl), 233(13):2593-2605, 2016. PMCID: PMC5025873, PMID: 27146401.

[75] CP. King, JA. Tripi, AR. Hughson, AP. Horvath, AC. Lamparelli, KL. Holl, AS. Chitre, O. Polesskaya, K. Ishiwari, LC. Solberg Woods, AA. Palmer, TE. Robinson, SB. Flagel, and PJ. Meyer. Sensitivity to food and cocaine cues are independent traits in a large sample of heterogeneous stock rats. Sci Rep, 11(1):2223, 2021. PMCID: PMC7838206, PMID: 33500444. 
[76] S. Sedighim, LL. Carrette, M. Venniro, Y. Shaham, G. de Guglielmo, and O. George. Individual differences in addiction-like behaviors and choice between cocaine versus food in heterogeneous stock rats. Psychopharmacology (Berl), 2021. PMID: 34415376.

[77] J. Gelernter, HR. Kranzler, R. Sherva, L. Almasy, R. Koesterer, AH. Smith, R. Anton, UW. Preuss, M. Ridinger, D. Rujescu, N. Wodarz, P. Zill, H. Zhao, and LA. Farrer. Genome-wide association study of alcohol dependence:significant findings in african- and european-americans including novel risk loci. Mol Psychiatry, 19(1):41-49, 2014. PMCID: PMC4165335, PMID: 24166409.

[78] M. Boucquey, E. De Plaen, M. Locker, A. Poliard, S. Mouillet-Richard, T. Boon, and O. Kellermann. Noxp20 and noxp70, two new markers of early neuronal differentiation, detected in teratocarcinoma-derived neuroectodermic precursor cells. J Neurochem, 99(2):657-669, 2006. PMID: 17029606.

[79] TB. Bigdeli, AH. Fanous, Y. Li, N. Rajeevan, F. Sayward, G. Genovese, R. Gupta, K. Radhakrishnan, AK. Malhotra, N. Sun, Q. Lu, Y. Hu, B. Li, Q. Chen, S. Mane, P. Miller, KH. Cheung, RE. Gur, TA. Greenwood, DL. Braff, ED. Achtyes, PF. Buckley, MA. Escamilla, D. Lehrer, DP. Malaspina, SA. McCarroll, MH. Rapaport, MP. Vawter, MT. Pato, CN. Pato, H. Zhao, TR. Kosten, M. Brophy, S. Pyarajan, Y. Shi, TJ. O'Leary, T. Gleason, R. Przygodzki, S. Muralidhar, JM. Gaziano, GD. Huang, J. Concato, LJ. Siever, M. Aslan, and PD. Harvey. Genome-wide association studies of schizophrenia and bipolar disorder in a diverse cohort of us veterans. Schizophr Bull, 47(2):517-529, 2021. PMCID: PMC7965063, PMID: 33169155.

[80] M. Lam, WD. Hill, JW. Trampush, J. Yu, E. Knowles, G. Davies, E. Stahl, L. Huckins, DC. Liewald, S. Djurovic, I. Melle, K. Sundet, A. Christoforou, I. Reinvang, P. DeRosse, AJ. Lundervold, VM. Steen, T. Espeseth, K. Räikkönen, E. Widen, A. Palotie, JG. Eriksson, I. Giegling, B. Konte, AM. Hartmann, P. Roussos, S. Giakoumaki, KE. Burdick, A. Payton, W. Ollier, O. Chiba-Falek, DK. Attix, AC. Need, ET. Cirulli, AN. Voineskos, NC. Stefanis, D. Avramopoulos, A. Hatzimanolis, DE. Arking, N. Smyrnis, RM. Bilder, NA. Freimer, TD. Cannon, E. London, RA. Poldrack, FW. Sabb, E. Congdon, ED. Conley, MA. Scult, D. Dickinson, RE. Straub, G. Donohoe, 
D. Morris, A. Corvin, M. Gill, AR. Hariri, DR. Weinberger, N. Pendleton, P. Bitsios, D. Rujescu, J. Lahti, S. Le Hellard, MC. Keller, OA. Andreassen, IJ. Deary, DC. Glahn, AK. Malhotra, and T. Lencz. Pleiotropic metaanalysis of cognition, education, and schizophrenia differentiates roles of early neurodevelopmental and adult synaptic pathways. Am J Hum Genet, 105(2):334-350, 2019. PMCID: PMC6699140, PMID: 31374203.

[81] M. Nagel, PR. Jansen, S. Stringer, K. Watanabe, CA. de Leeuw, J. Bryois, JE. Savage, AR. Hammerschlag, NG. Skene, AB. Muñoz-Manchado, T. White, H. Tiemeier, S. Linnarsson, J. Hjerling-Leffler, TJC. Polderman, PF. Sullivan, S. van der Sluis, and D. Posthuma. Meta-analysis of genomewide association studies for neuroticism in 449,484 individuals identifies novel genetic loci and pathways. Nat Genet, 50(7):920-927, 2018. PMID: 29942085.

[82] J. Hu, G. Li, L. Qu, N. Li, W. Liu, D. Xia, B. Hongdu, X. Lin, C. Xu, Y. Lou, Q. He, D. Ma, and Y. Chen. Tmem166/eva1a interacts with atg1611 and induces autophagosome formation and cell death. Cell Death Dis, 7(8):e2323, 2016. PMCID: PMC5108317, PMID: 27490928.

[83] A. Fine, V. Irihimovitch, I. Dahan, Z. Konrad, and J. Eichler. Cloning, expression, and purification of functional sec11a and sec11b, type i signal peptidases of the archaeon haloferax volcanii. J Bacteriol, 188(5):1911-1919, 2006. PMCID: PMC1426568, PMID: 16484202.

[84] J. Yang, D. Cao, Y. Zhang, R. Ou, Z. Yin, Y. Liu, G. Huang, C. Gu, S. Chen, and J. Fei. The role of phosphorylation of mlf2 at serine 24 in bcr-abl leukemogenesis. Cancer Gene Ther, 27(1-2):98-9107, 2020. PMID: 31831854 .

[85] JRI. Coleman, HA. Gaspar, J. Bryois, and G. Breen. The genetics of the mood disorder spectrum: Genome-wide association analyses of more than 185,000 cases and 439,000 controls. Biol Psychiatry, 88(2):169-184, 2020. PMCID: PMC8136147, PMID: 31926635.

[86] NR. Wray, S. Ripke, M. Mattheisen, M. Trzaskowski, EM. Byrne, A. Abdellaoui, MJ. Adams, E. Agerbo, TM. Air, TMF. Andlauer, SA. Bacanu, M. Bækvad-Hansen, AFT. Beekman, TB. Bigdeli, EB. Binder, DRH. Blackwood, J. Bryois, HN. Buttenschøn, J. Bybjerg-Grauholm, N. Cai, E. Castelao, JH. Christensen, TK. Clarke, JIR. Coleman, L. Colodro-Conde, 
B. Couvy-Duchesne, N. Craddock, GE. Crawford, CA. Crowley, HS. Dashti, G. Davies, IJ. Deary, F. Degenhardt, EM. Derks, N. Direk, CV. Dolan, EC. Dunn, TC. Eley, N. Eriksson, V. Escott-Price, FHF. Kiadeh, HK. Finucane, AJ. Forstner, J. Frank, HA. Gaspar, M. Gill, P. Giusti-Rodríguez, FS. Goes, SD. Gordon, J. Grove, LS. Hall, E. Hannon, CS. Hansen, TF. Hansen, S. Herms, IB. Hickie, P. Hoffmann, G. Homuth, C. Horn, JJ. Hottenga, DM. Hougaard, M. Hu, CL. Hyde, M. Ising, R. Jansen, F. Jin, E. Jorgenson, JA. Knowles, IS. Kohane, J. Kraft, WW. Kretzschmar, J. Krogh, Z. Kutalik, JM. Lane, Y. Li, Y. Li, PA. Lind, X. Liu, L. Lu, DJ. MacIntyre, DF. MacKinnon, RM. Maier, W. Maier, J. Marchini, H. Mbarek, P. McGrath, P. McGuffin, SE. Medland, D. Mehta, CM. Middeldorp, E. Mihailov, Y. Milaneschi, L. Milani, J. Mill, FM. Mondimore, GW. Montgomery, S. Mostafavi, N. Mullins, M. Nauck, B. Ng, MG. Nivard, DR. Nyholt, PF. O'Reilly, H. Oskarsson, MJ. Owen, JN. Painter, CB. Pedersen, MG. Pedersen, RE. Peterson, E. Pettersson, WJ. Peyrot, G. Pistis, D. Posthuma, SM. Purcell, JA. Quiroz, P. Qvist, JP. Rice, BP. Riley, M. Rivera, S. Saeed Mirza, R. Saxena, R. Schoevers, EC. Schulte, L. Shen, J. Shi, SI. Shyn, E. Sigurdsson, GBC. Sinnamon, JH. Smit, DJ. Smith, H. Stefansson, S. Steinberg, CA. Stockmeier, F. Streit, J. Strohmaier, KE. Tansey, H. Teismann, A. Teumer, W. Thompson, PA. Thomson, TE. Thorgeirsson, C. Tian, M. Traylor, J. Treutlein, V. Trubetskoy, AG. Uitterlinden, D. Umbricht, S. Van der Auwera, AM. van Hemert, A. Viktorin, PM. Visscher, Y. Wang, BT. Webb, SM. Weinsheimer, J. Wellmann, G. Willemsen, SH. Witt, Y. Wu, HS. Xi, J. Yang, F. Zhang, V. Arolt, BT. Baune, K. Berger, DI. Boomsma, S. Cichon, U. Dannlowski, ECJ. de Geus, JR. DePaulo, E. Domenici, K. Domschke, T. Esko, HJ. Grabe, SP. Hamilton, C. Hayward, AC. Heath, DA. Hinds, KS. Kendler, S. Kloiber, G. Lewis, QS. Li, S. Lucae, PFA. Madden, PK. Magnusson, NG. Martin, AM. McIntosh, A. Metspalu, O. Mors, PB. Mortensen, B. Müller-Myhsok, M. Nordentoft, MM. Nöthen, MC. O'Donovan, SA. Paciga, NL. Pedersen, BWJH. Penninx, RH. Perlis, DJ. Porteous, JB. Potash, M. Preisig, M. Rietschel, C. Schaefer, TG. Schulze, JW. Smoller, K. Stefansson, H. Tiemeier, R. Uher, H. Völzke, MM. Weissman, T. Werge, AR. Winslow, CM. Lewis, DF. Levinson, G. Breen, AD. Børglum, and PF. Sullivan. Genome-wide association analyses identify 44 risk variants and refine the genetic architecture of major depression. Nat Genet, 50(5):668-681, 2018. PMCID: PMC5934326, PMID: 29700475. 
[87] D. Chen, J. Guo, T. Miki, M. Tachibana, and WA. Gahl. Molecular cloning and characterization of rab27a and rab27b, novel human rab proteins shared by melanocytes and platelets. Biochem Mol Med, 60(1):27-37, 1997. PMID: 9066979 .

[88] DM. Brazel, Y. Jiang, JM. Hughey, V. Turcot, X. Zhan, J. Gong, C. Batini, JD. Weissenkampen, M. Liu, DR. Barnes, S. Bertelsen, YL. Chou, AM. Erzurumluoglu, JD. Faul, J. Haessler, AR. Hammerschlag, C. Hsu, M. Kapoor, D. Lai, N. Le, CA. de Leeuw, A. Loukola, M. Mangino, CA. Melbourne, G. Pistis, B. Qaiser, R. Rohde, Y. Shao, H. Stringham, L. Wetherill, W. Zhao, A. Agrawal, L. Bierut, C. Chen, CB. Eaton, A. Goate, C. Haiman, A. Heath, WG. Iacono, NG. Martin, TJ. Polderman, A. Reiner, J. Rice, D. Schlessinger, HS. Scholte, JA. Smith, JC. Tardif, HA. Tindle, AR. van der Leij, M. Boehnke, J. Chang-Claude, F. Cucca, SP. David, T. Foroud, JMM. Howson, SLR. Kardia, C. Kooperberg, M. Laakso, G. Lettre, P. Madden, M. McGue, K. North, D. Posthuma, T. Spector, D. Stram, MD. Tobin, DR. Weir, J. Kaprio, GR. Abecasis, DJ. Liu, and S. Vrieze. Exome chip meta-analysis fine maps causal variants and elucidates the genetic architecture of rare coding variants in smoking and alcohol use. Biol Psychiatry, 85(11):946-955, 2019. PMCID: PMC6534468, PMID: 30679032.

[89] S. Sanchez-Roige, P. Fontanillas, SL. Elson, JC. Gray, H. de Wit, LK. Davis, J. MacKillop, and AA. Palmer. Genome-wide association study of alcohol use disorder identification test (audit) scores in 20328 research participants of european ancestry. Addict Biol, 24(1):121-131, 2019. PMCID: PMC6988186, PMID: 29058377.

[90] G. Kempermann, EJ. Chesler, L. Lu, RW. Williams, and FH. Gage. Natural variation and genetic covariance in adult hippocampal neurogenesis. Proc Natl Acad Sci U S A, 103(3):780-785, 2006. PMCID: PMC1325968, PMID: 16407118.

[91] SB. Huggett and MC. Stallings. Genetic architecture and molecular neuropathology of human cocaine addiction. J Neurosci, 40(27):5300-5313, 2020. PMCID: PMC7329314, PMID: 32457073.

[92] YJ. Sung, TW. Winkler, L. de Las Fuentes, AR. Bentley, MR. Brown, AT. Kraja, K. Schwander, I. Ntalla, X. Guo, N. Franceschini, Y. Lu, CY. Cheng, X. Sim, D. Vojinovic, J. Marten, SK. Musani, C. Li, MF. Feitosa, TO. Kilpeläinen, MA. Richard, R. Noordam, S. Aslibekyan, H. Aschard, 
TM. Bartz, R. Dorajoo, Y. Liu, AK. Manning, T. Rankinen, AV. Smith, SM. Tajuddin, BO. Tayo, HR. Warren, W. Zhao, Y. Zhou, N. Matoba, T. Sofer, M. Alver, M. Amini, M. Boissel, JF. Chai, X. Chen, J. Divers, I. Gandin, C. Gao, F. Giulianini, A. Goel, SE. Harris, FP. Hartwig, ARVR. Horimoto, FC. Hsu, AU. Jackson, M. Kähönen, A. Kasturiratne, B. Kühnel, K. Leander, WJ. Lee, KH. Lin, J. 'an Luan, CA. McKenzie, H. Meian, CP. Nelson, R. Rauramaa, N. Schupf, RA. Scott, WHH. Sheu, A. Stančáková, F. Takeuchi, PJ. van der Most, TV. Varga, H. Wang, Y. Wang, EB. Ware, S. Weiss, W. Wen, LR. Yanek, W. Zhang, JH. Zhao, S. Afaq, T. Alfred, N. Amin, D. Arking, T. Aung, RG. Barr, LF. Bielak, E. Boerwinkle, EP. Bottinger, PS. Braund, JA. Brody, U. Broeckel, CP. Cabrera, B. Cade, Y. Caizheng, A. Campbell, M. Canouil, A. Chakravarti, G. Chauhan, K. Christensen, M. Cocca, FS. Collins, JM. Connell, R. de Mutsert, HJ. de Silva, S. Debette, M. Dörr, Q. Duan, CB. Eaton, G. Ehret, E. Evangelou, JD. Faul, VA. Fisher, NG. Forouhi, OH. Franco, Y. Friedlander, H. Gao, B. Gigante, M. Graff, CC. Gu, D. Gu, P. Gupta, SP. Hagenaars, TB. Harris, J. He, S. Heikkinen, CK. Heng, M. Hirata, A. Hofman, BV. Howard, S. Hunt, MR. Irvin, Y. Jia, R. Joehanes, AE. Justice, T. Katsuya, J. Kaufman, ND. Kerrison, CC. Khor, WP. Koh, HA. Koistinen, P. Komulainen, C. Kooperberg, JE. Krieger, M. Kubo, J. Kuusisto, CD. Langefeld, C. Langenberg, LJ. Launer, B. Lehne, CE. Lewis, Y. Li, SH. Lim, S. Lin, CT. Liu, J. Liu, J. Liu, K. Liu, Y. Liu, M. Loh, KK. Lohman, J. Long, T. Louie, R. Mägi, A. Mahajan, T. Meitinger, A. Metspalu, L. Milani, Y. Momozawa, AP. Morris, TH. Mosley, P. Munson, AD. Murray, MA. Nalls, U. Nasri, JM. Norris, K. North, A. Ogunniyi, S. Padmanabhan, WR. Palmas, ND. Palmer, JS. Pankow, NL. Pedersen, A. Peters, PA. Peyser, O. Polasek, OT. Raitakari, F. Renström, TK. Rice, PM. Ridker, A. Robino, JG. Robinson, LM. Rose, I. Rudan, C. Sabanayagam, BL. Salako, K. Sandow, CO. Schmidt, PJ. Schreiner, WR. Scott, S. Seshadri, P. Sever, CM. Sitlani, JA. Smith, H. Snieder, JM. Starr, K. Strauch, H. Tang, KD. Taylor, YY. Teo, YC. Tham, AG. Uitterlinden, M. Waldenberger, L. Wang, YX. Wang, WB. Wei, C. Williams, G. Wilson, MK. Wojczynski, J. Yao, JM. Yuan, AB. Zonderman, DM. Becker, M. Boehnke, DW. Bowden, JC. Chambers, YI. Chen, U. de Faire, IJ. Deary, T. Esko, M. Farrall, T. Forrester, PW. Franks, BI. Freedman, P. Froguel, P. Gasparini, C. Gieger, BL. Horta, YJ. Hung, JB. Jonas, N. Kato, JS. Kooner, M. Laakso, T. Lehtimäki, KW. Liang, PKE. Magnusson, AB. Newman, AJ. Oldehinkel, AC. Pereira, 
S. Redline, R. Rettig, NJ. Samani, J. Scott, XO. Shu, P. van der Harst, LE. Wagenknecht, NJ. Wareham, H. Watkins, DR. Weir, AR. Wickremasinghe, T. Wu, W. Zheng, Y. Kamatani, CC. Laurie, C. Bouchard, RS. Cooper, MK. Evans, V. Gudnason, SLR. Kardia, SB. Kritchevsky, D. Levy, JR. O'Connell, BM. Psaty, RM. van Dam, M. Sims, DK. Arnett, DO. Mook-Kanamori, TN. Kelly, ER. Fox, C. Hayward, M. Fornage, CN. Rotimi, MA. Province, CM. van Duijn, ES. Tai, TY. Wong, RJF. Loos, AP. Reiner, JI. Rotter, X. Zhu, LJ. Bierut, WJ. Gauderman, MJ. Caulfield, P. Elliott, K. Rice, PB. Munroe, AC. Morrison, LA. Cupples, DC. Rao, and DI. Chasman. A large-scale multi-ancestry genome-wide study accounting for smoking behavior identifies multiple significant loci for blood pressure. Am J Hum Genet, 102(3):375-400, 2018. PMCID: PMC5985266, PMID: 29455858.

[93] L. Mittaz, SE. Antonarakis, M. Higuchi, and HS. Scott. Localization of a novel human rna-editing deaminase (hred2 or adarb2) to chromosome 10p15. Hum Genet, 100(3-4):398-400, 1997. PMID: 9272162.

[94] P. Chaste, L. Klei, SJ. Sanders, V. Hus, MT. Murtha, JK. Lowe, AJ. Willsey, D. Moreno-De-Luca, TW. Yu, E. Fombonne, D. Geschwind, DE. Grice, DH. Ledbetter, SM. Mane, DM. Martin, EM. Morrow, CA. Walsh, JS. Sutcliffe, C. Lese Martin, AL. Beaudet, C. Lord, MW. State, EH. Cook, and B. Devlin. A genome-wide association study of autism using the simons simplex collection: Does reducing phenotypic heterogeneity in autism increase genetic homogeneity? Biol Psychiatry, 77(9):775-784, 2015. PMCID: PMC4379124, PMID: 25534755.

[95] M. Yamakage and A. Namiki. Calcium channels-basic aspects of their structure, function and gene encoding; anesthetic action on the channels-a review. Can J Anaesth, 49(2):151-164, 2002. PMID: 11823393.

[96] J. Mendoza. Food intake and addictive-like eating behaviors: Time to think about the circadian clock(s). Neurosci Biobehav Rev, 106:122-132, 2019. PMID: 29990504.

[97] NL. Salaberry and J. Mendoza. Insights into the role of the habenular circadian clock in addiction. Front Psychiatry, 6:179, 2015. PMCID: PMC4700272, PMID: 26779042.

[98] A. Buniello, JAL. MacArthur, M. Cerezo, LW. Harris, J. Hayhurst, C. Malangone, A. McMahon, J. Morales, E. Mountjoy, E. Sollis, D. Suveges, O. Vrous- 
gou, PL. Whetzel, R. Amode, JA. Guillen, HS. Riat, SJ. Trevanion, P. Hall, H. Junkins, P. Flicek, T. Burdett, LA. Hindorff, F. Cunningham, and H. Parkinson. The nhgri-ebi gwas catalog of published genome-wide association studies, targeted arrays and summary statistics 2019. Nucleic Acids Res, 47(D1):D1005-D1012, 2019. PMCID: PMC6323933, PMID: 30445434.

Table 1: Heritability of open field (OFT), novel object (NOIT) and social interaction (SIT) tests

\begin{tabular}{llc}
\hline Test & Trait & Heritability \pm SE \\
\hline OFT & Duration in center zone & $0.284 \pm 0.045$ \\
& Frequency of entering center zone & $0.323 \pm 0.044$ \\
& Latency of entering center zone & $0.083 \pm 0.034$ \\
& Mean distance to center zone & $0.295 \pm 0.043$ \\
& Total distance to center zone & $0.300 \pm 0.043$ \\
& Total travel distance & $0.379 \pm 0.044$ \\
\hline NOIT & Duration in center zone & $0.247 \pm 0.043$ \\
& Frequency of entering center zone & $0.209 \pm 0.041$ \\
& Latency of entering center zone & $0.100 \pm 0.034$ \\
& Mean distance to center zone & $0.249 \pm 0.042$ \\
& Total distance to center zone & $0.221 \pm 0.041$ \\
& Total travel distance & $0.287 \pm 0.044$ \\
\hline SIT & Duration in object zone & $0.161 \pm 0.037$ \\
& Duration in social zone & $0.275 \pm 0.040$ \\
& Frequency of entering object zone & $0.177 \pm 0.036$ \\
& Frequency of entering social zone & $0.215 \pm 0.036$ \\
& Latency of entering object zone & $0.082 \pm 0.032$ \\
& Latency of entering social zone & $0.142 \pm 0.034$ \\
& Mean distance to object zone & $0.165 \pm 0.038$ \\
& Mean distance to social zone & $0.265 \pm 0.041$ \\
& Total distance to object zone & $0.153 \pm 0.037$ \\
& Total distance to social zone & $0.265 \pm 0.041$ \\
& Total travel distance & $0.281 \pm 0.040$ \\
\hline
\end{tabular}


bioRxiv preprint doi: https://doi.org/10.1101/2021.10.18.464872; this version posted October 19,2021 . The copyright holder for this preprint (which was not certified by peer review) is the author/funder, who has granted bioRxiv a license to display the preprint in perpetuity. It is made available under aCC-BY 4.0 International license.

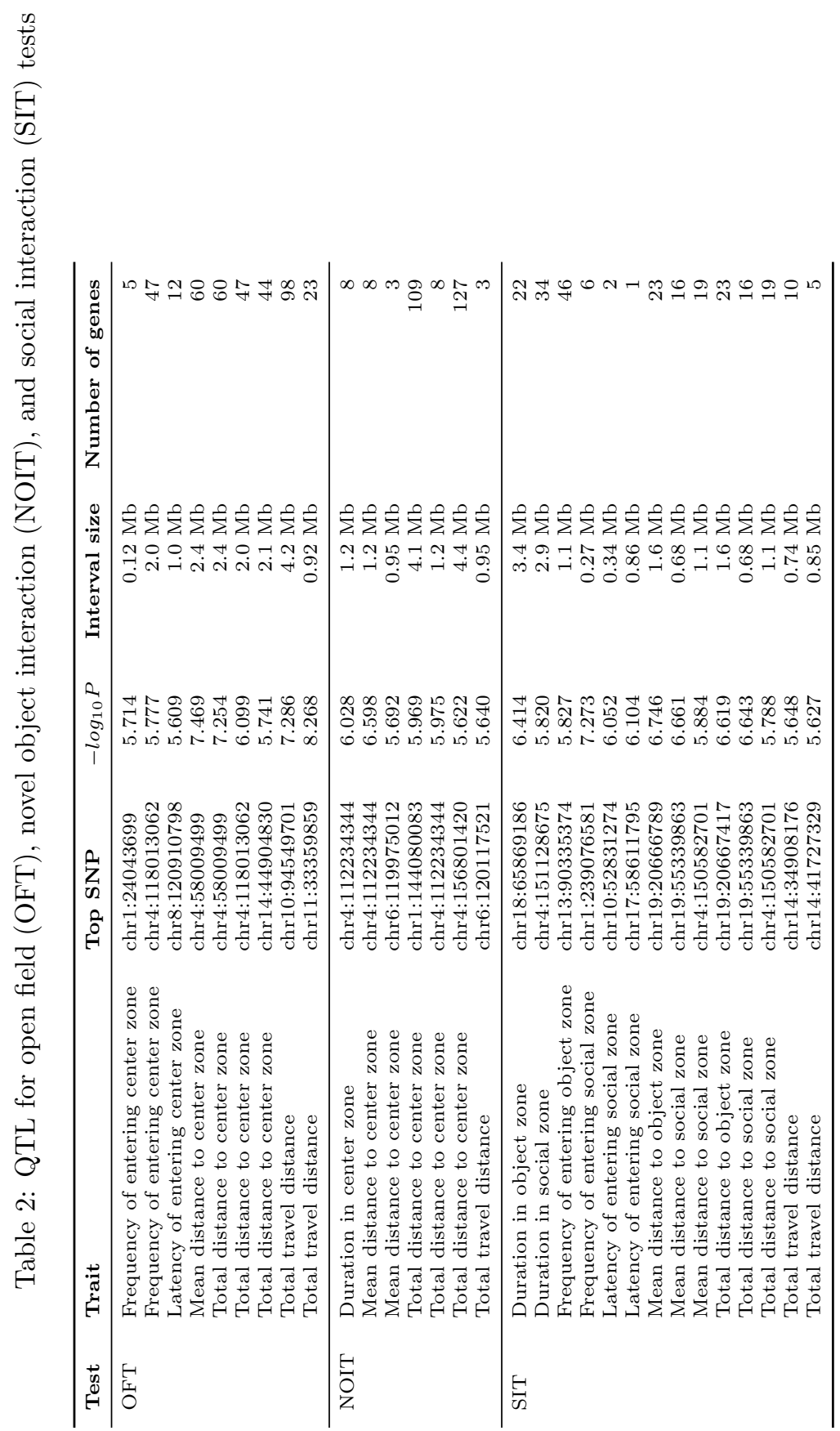




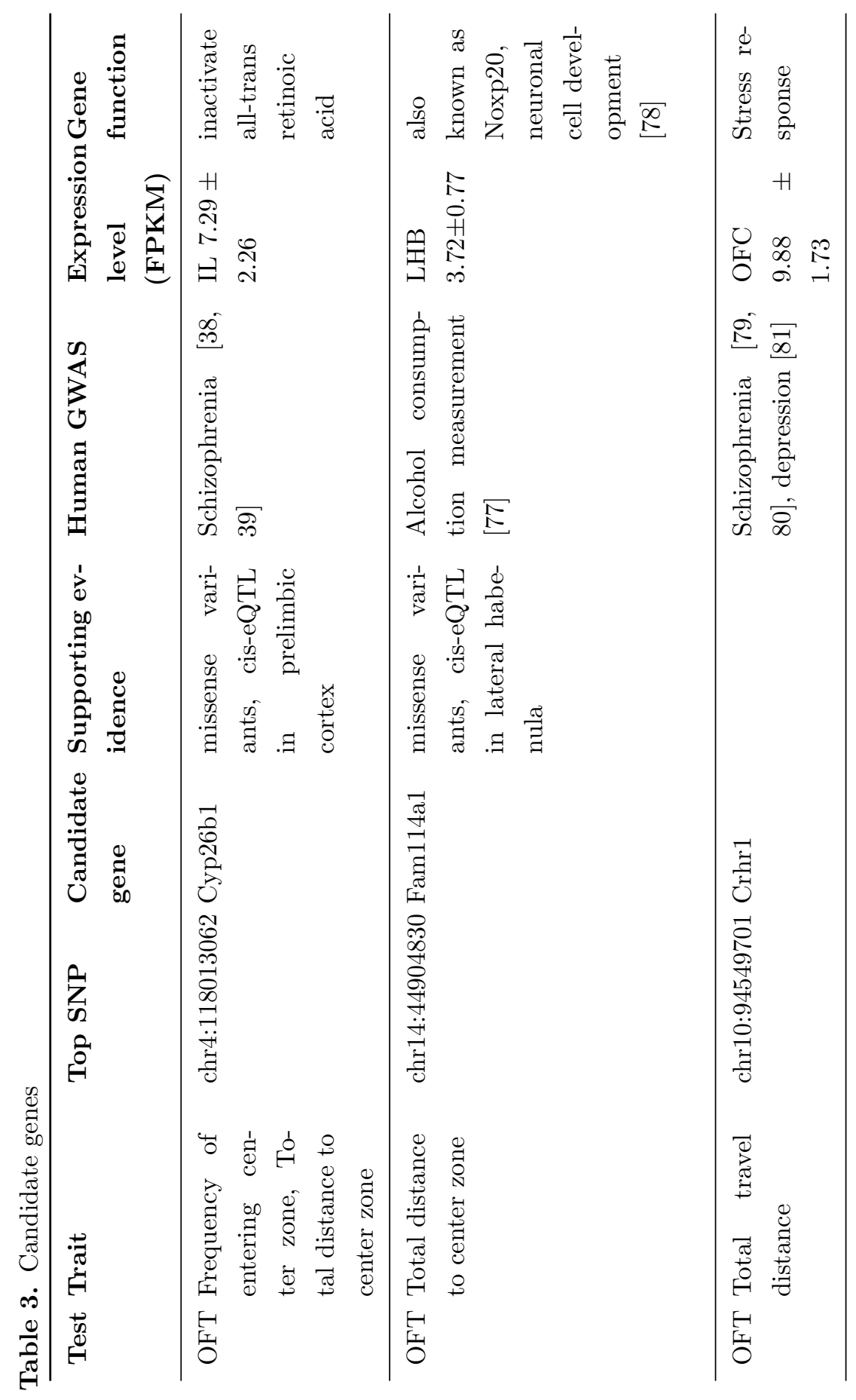




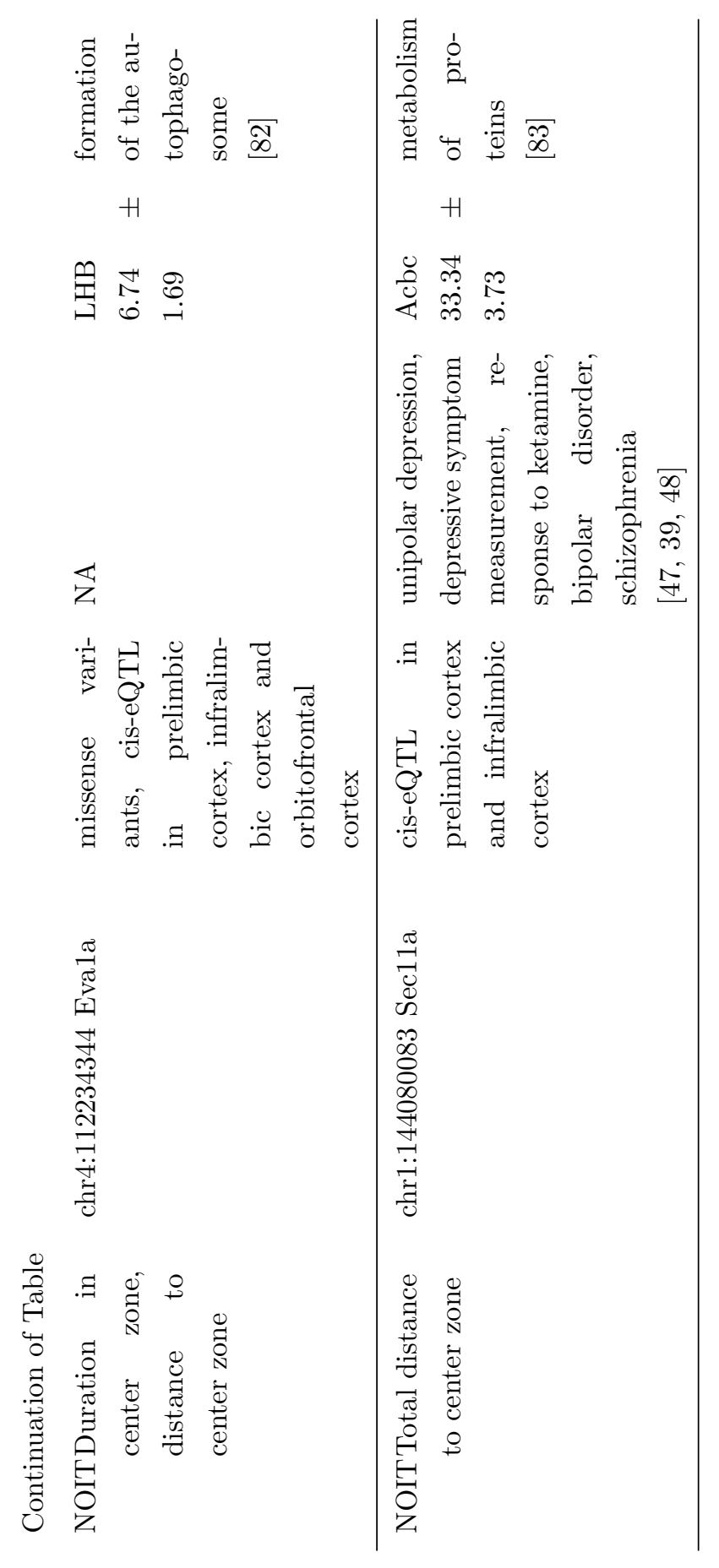




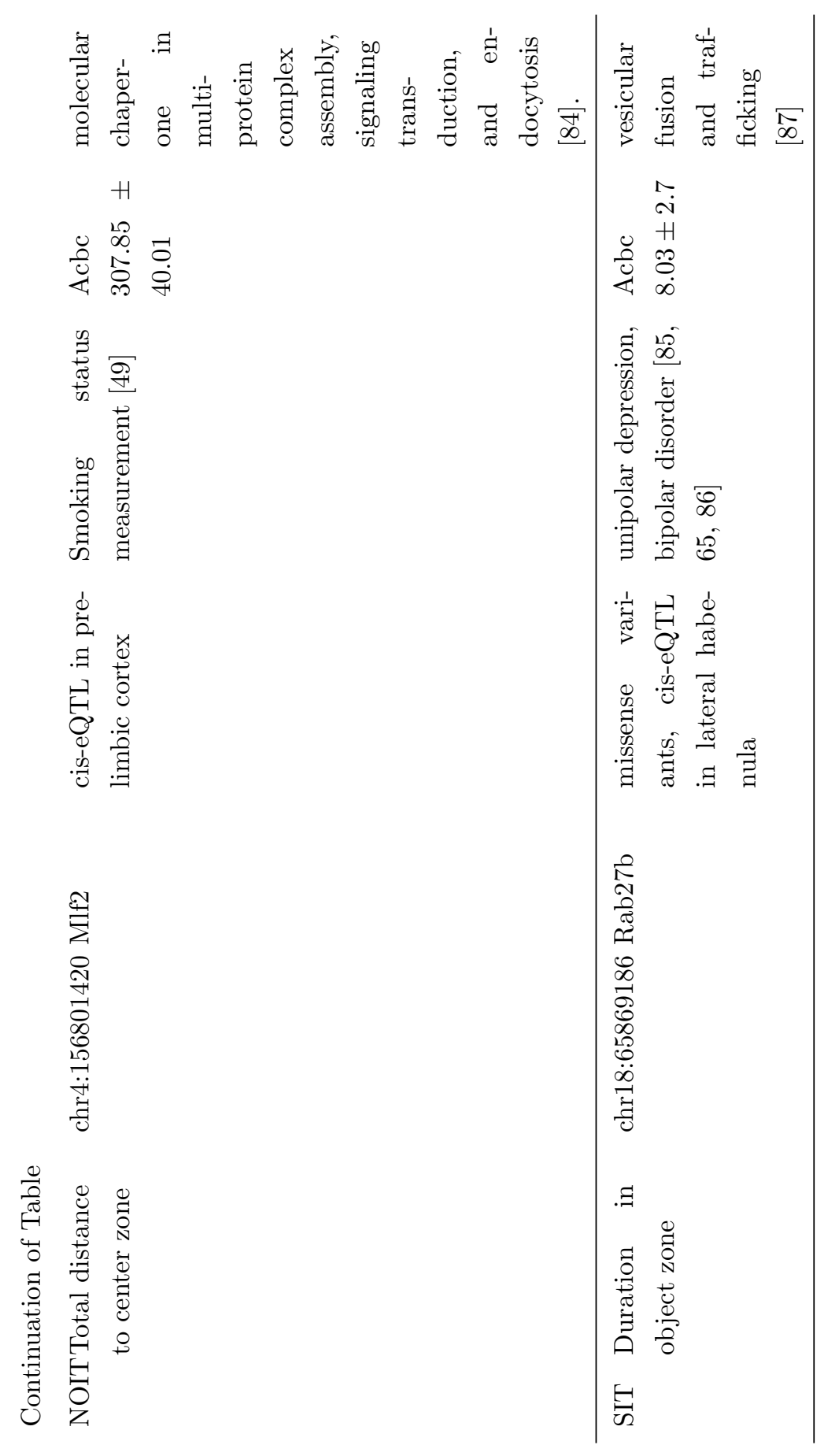




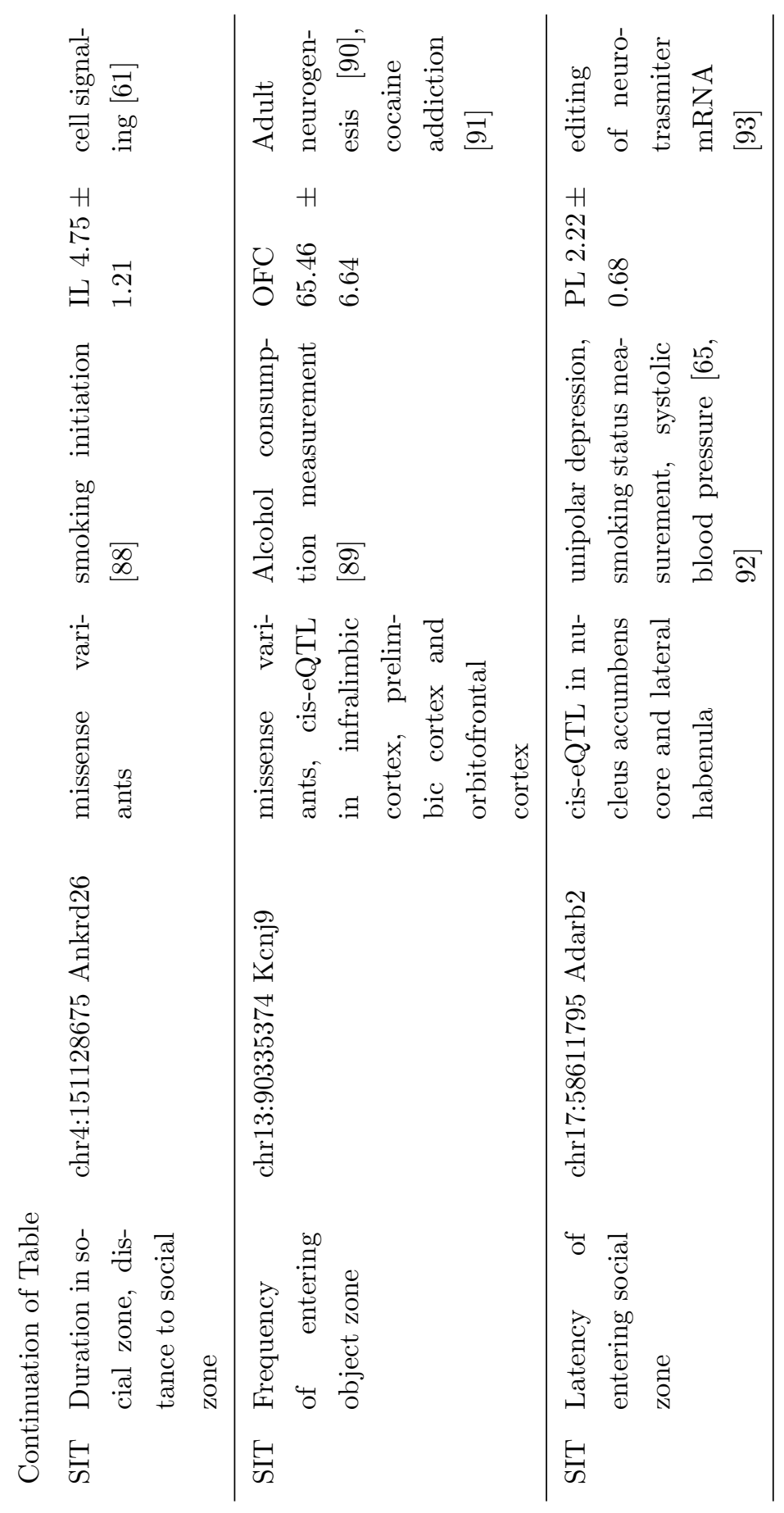




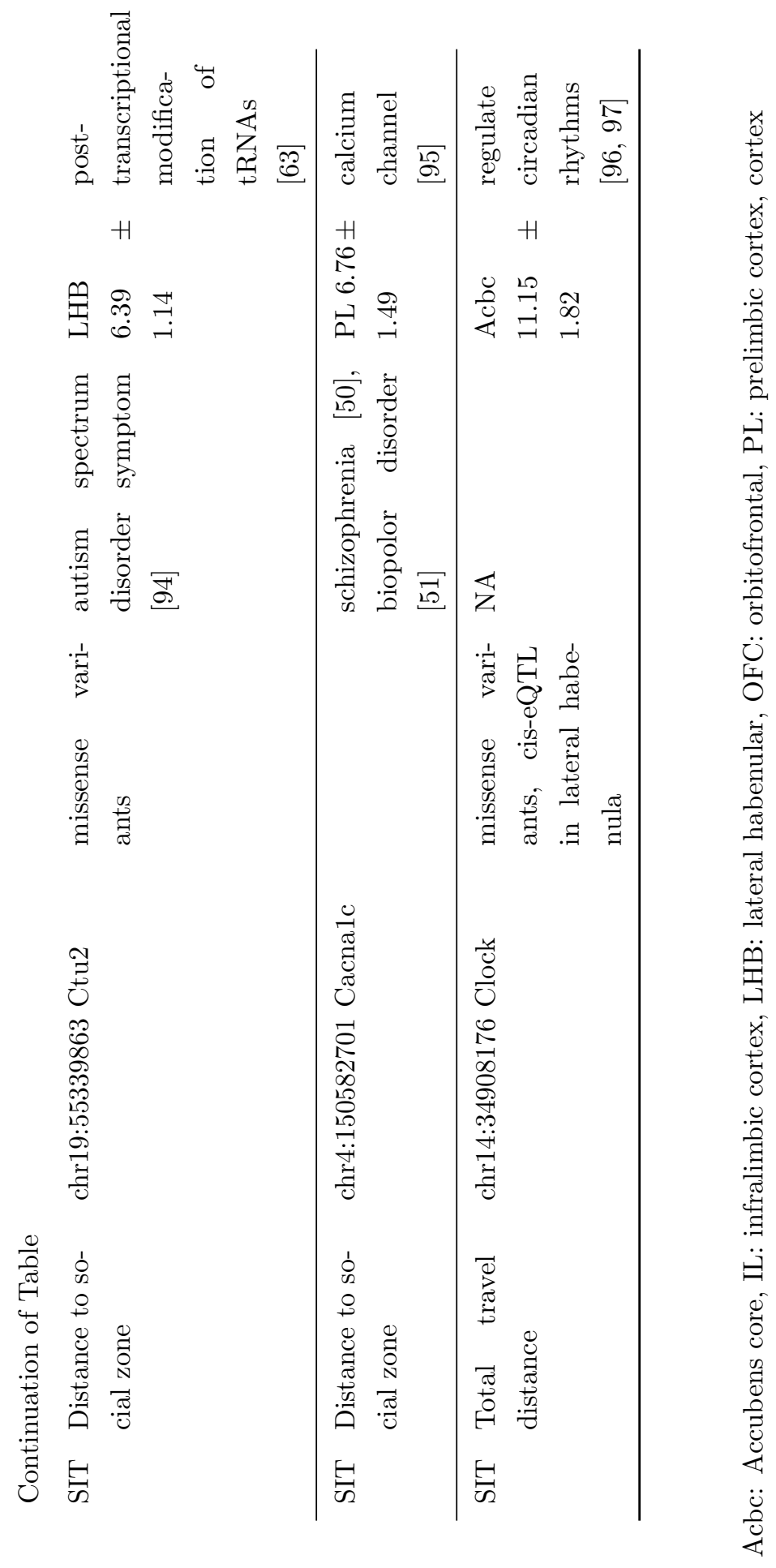


bioRxiv preprint doi: https://doi.org/10.1101/2021.10.18.464872; this version posted October 19, 2021. The copyright holder for this preprint (which was not certified by peer review) is the author/funder, who has granted bioRxiv a license to display the preprint in perpetuity. It is made available under aCC-BY 4.0 International license.

\section{Figures and captions}

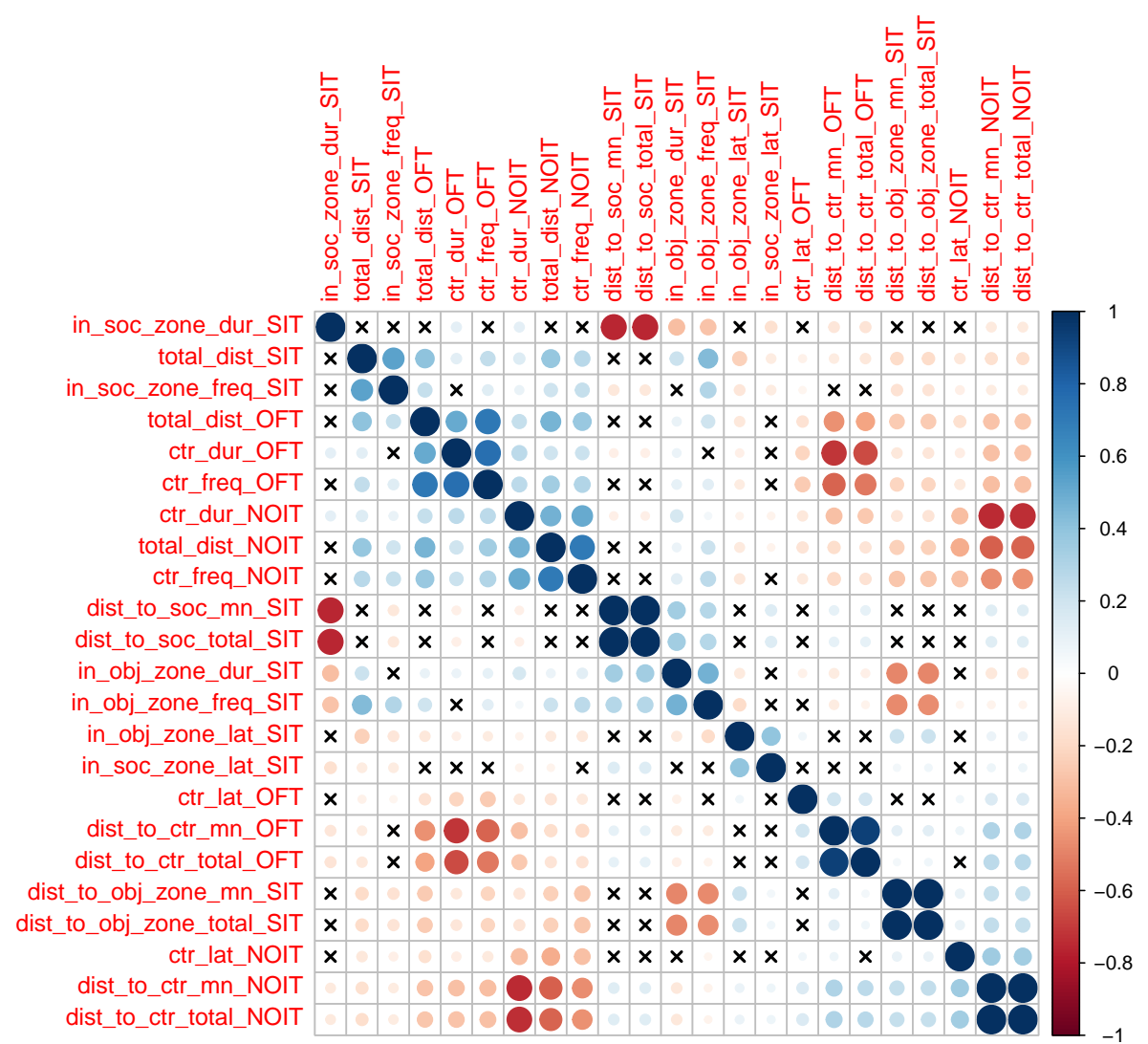

Figure 1: Heatmap showing the correlations between behavioral traits. The color scheme represents the direction of the correlation, whereas the intensity of the colors and the size of the circles are proportional to coefficients of the correlation. The cross signs indicates that the correlation of the two traits is not statistically significant $(p>0.05)$ 


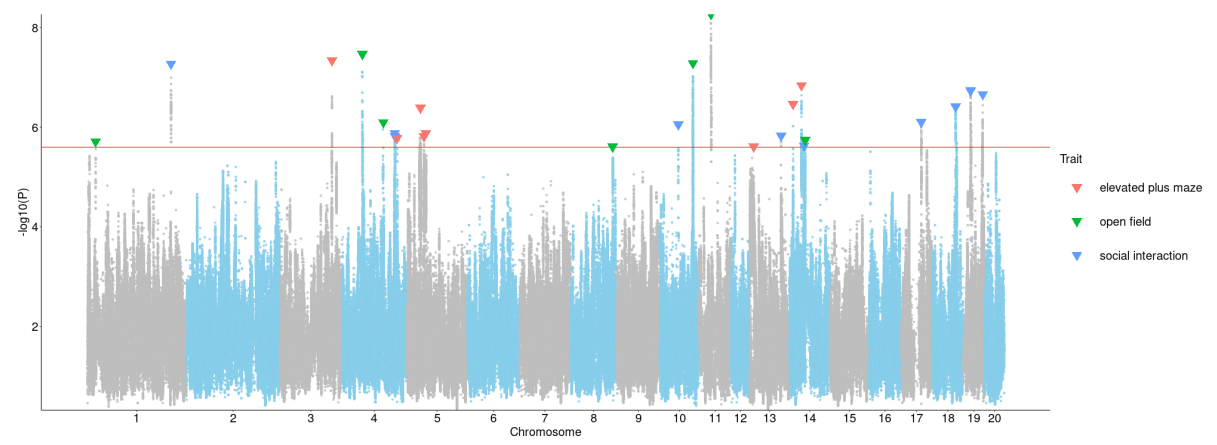

Figure 2: Association of approximately 3 million SNPs with behavioral traits measured in OFT, NOIT, or SIT. The red horizontal line denotes the p value for reaching genome-wide significance. The downward arrows denote the SNPs with the largest $-\log 10(\mathrm{P})$ for each genome-wide significant association.

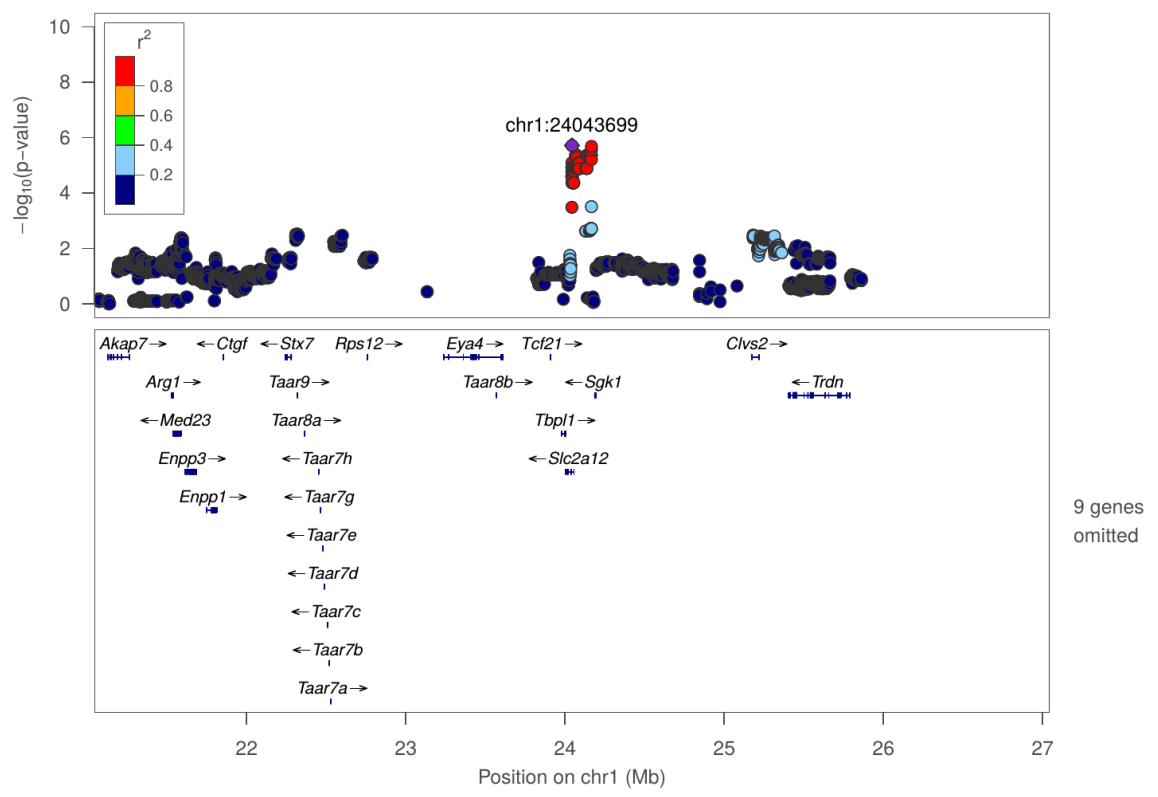

Figure 3: Regional association plot for frequency of entering center zone in OFT at $\operatorname{chr} 1: 24043699$ 
bioRxiv preprint doi: https://doi.org/10.1101/2021.10.18.464872; this version posted October 19,2021 . The copyright holder for this preprint (which was not certified by peer review) is the author/funder, who has granted bioRxiv a license to display the preprint in perpetuity. It is made available under aCC-BY 4.0 International license.

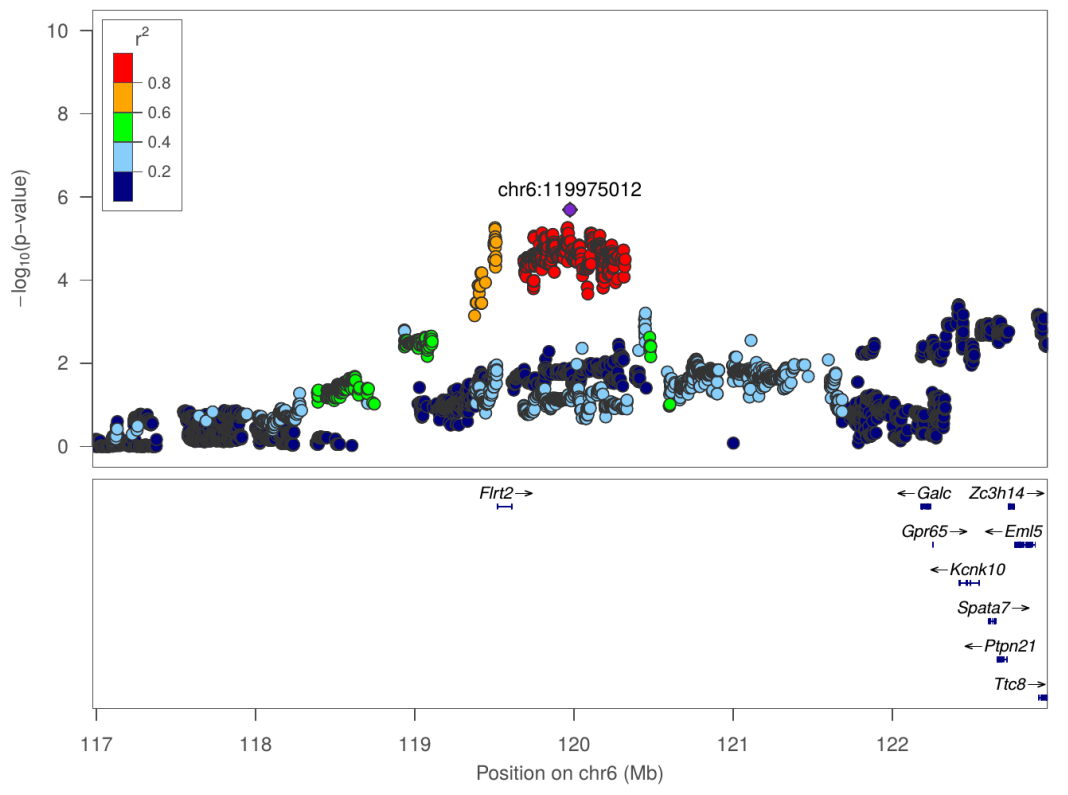

Figure 4: Regional association plot for mean distance to center zone in NOIT at chr6:119975012 
bioRxiv preprint doi: https://doi.org/10.1101/2021.10.18.464872; this version posted October 19, 2021. The copyright holder for this preprint (which was not certified by peer review) is the author/funder, who has granted bioRxiv a license to display the preprint in perpetuity. It is made available under aCC-BY 4.0 International license.

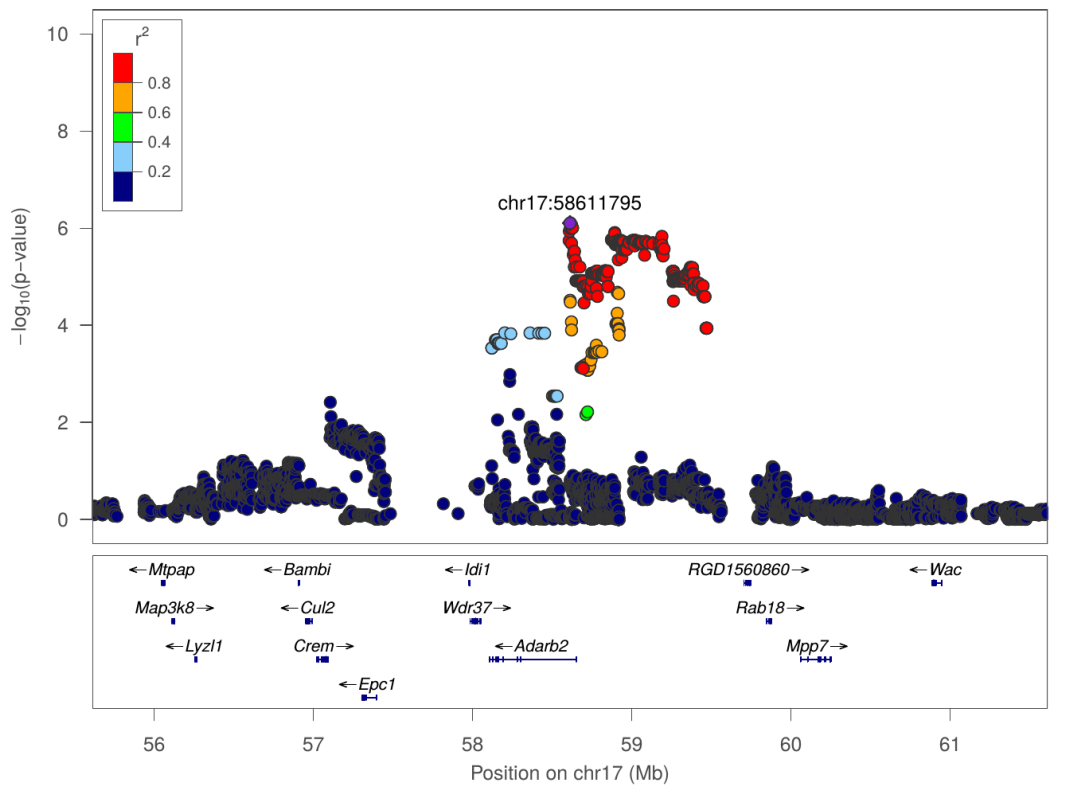

Figure 5: Regional association plot for latency of entering social zone in SIT at $\operatorname{chr} 17: 58611795$ 

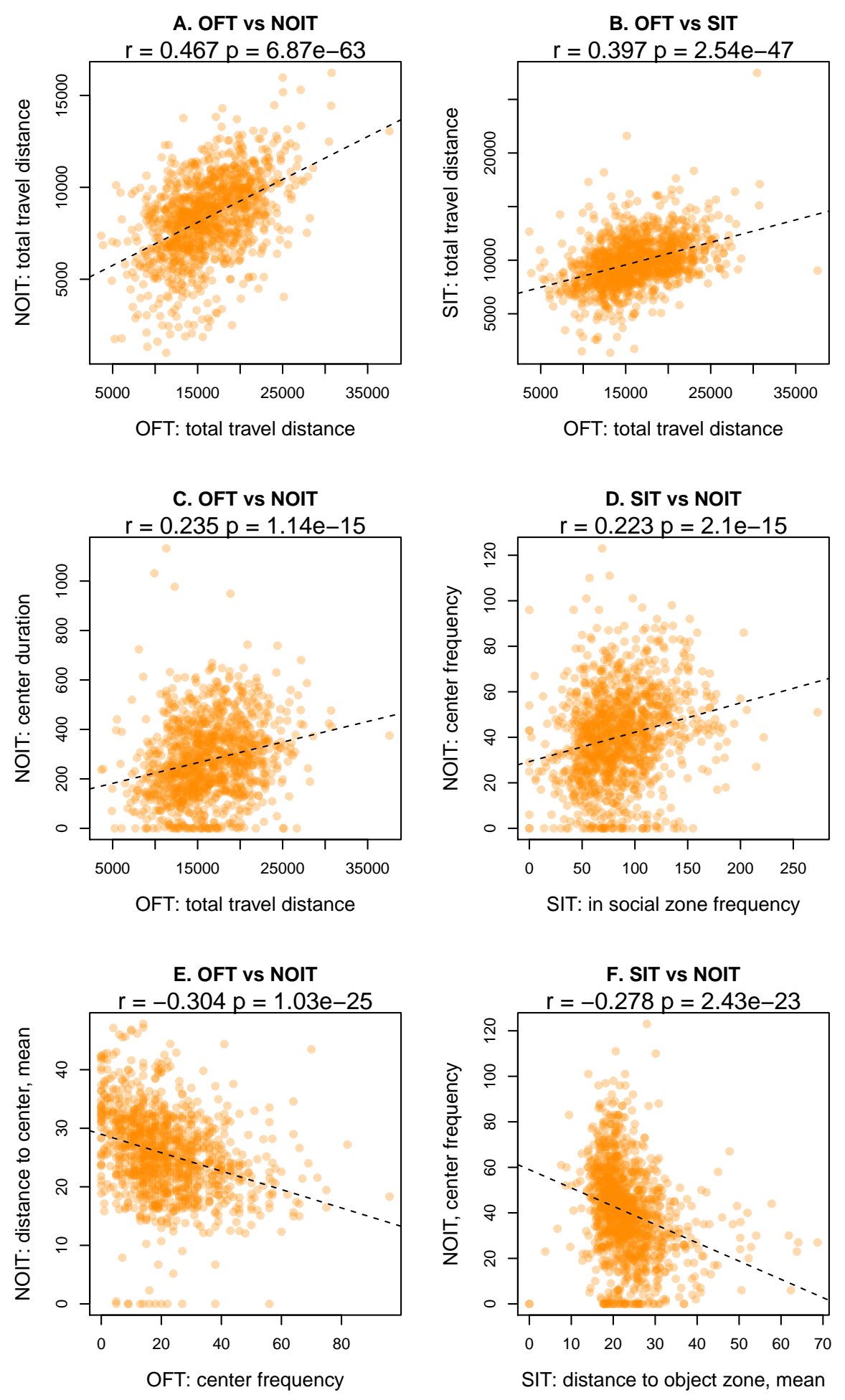

42

Figure 6: Selected scatter plots for correlation between behavioral tests shown in Figure 1. 


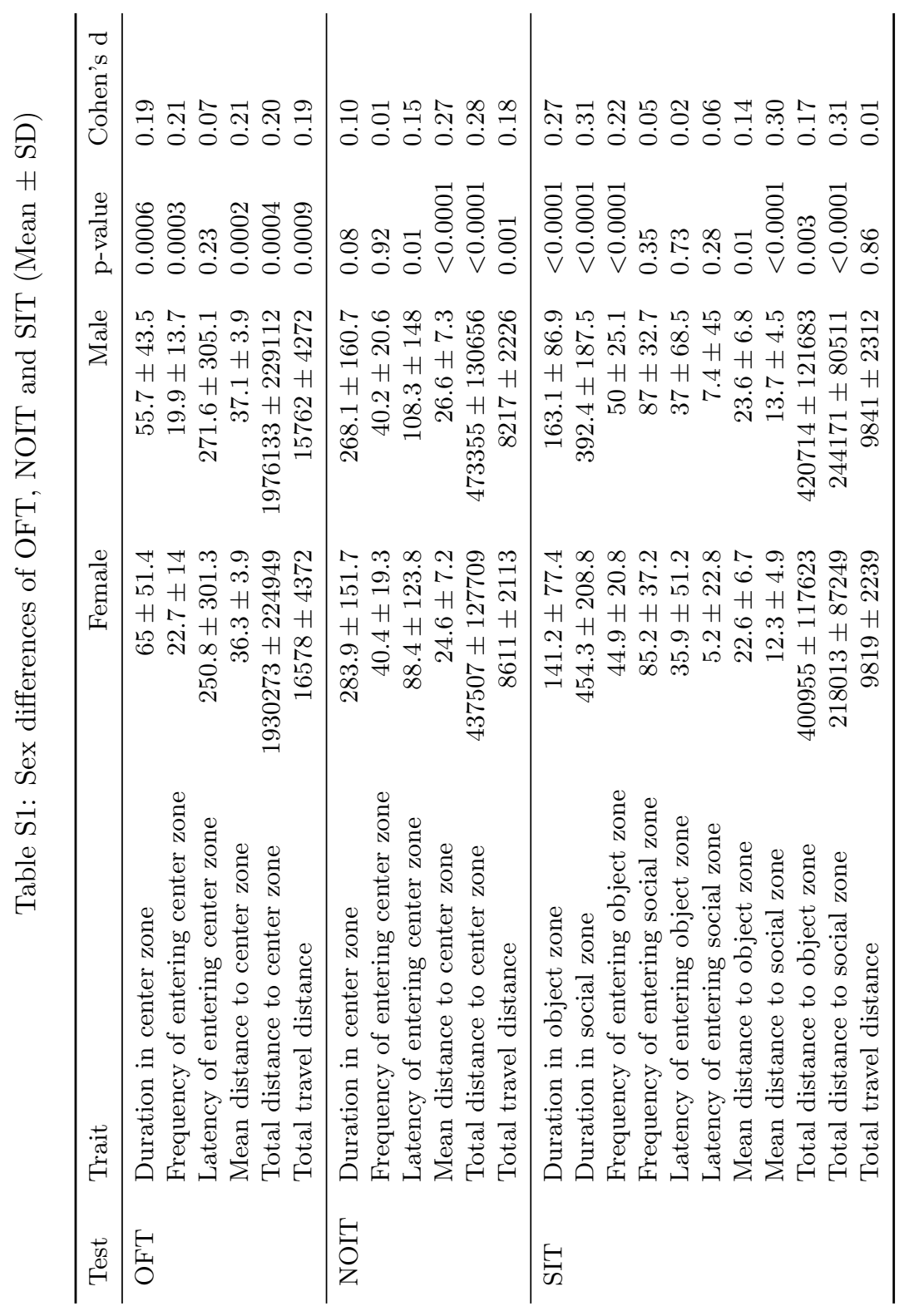




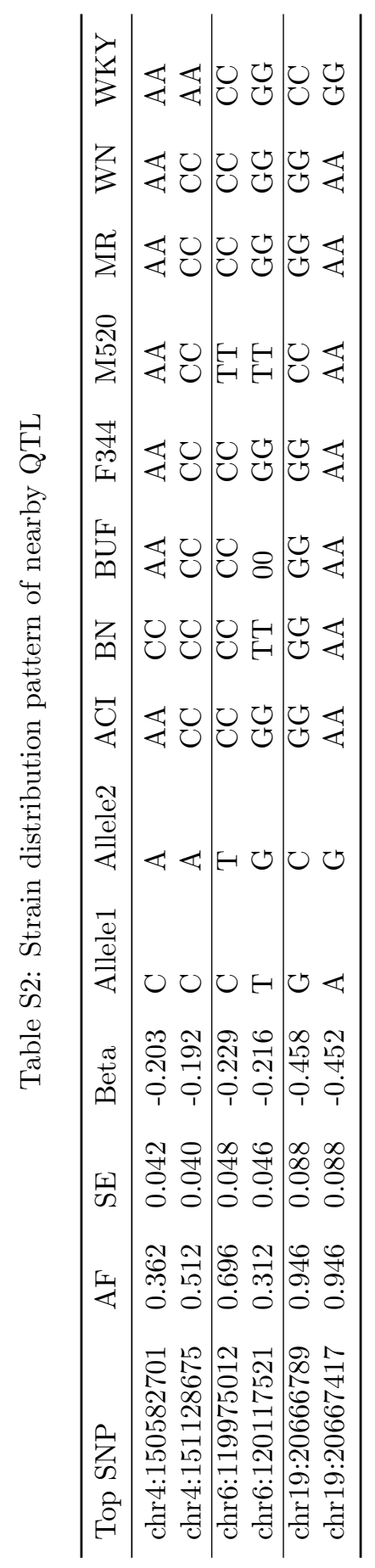


Table S3: Pleiotropic effects.

\begin{tabular}{|c|c|c|}
\hline Top SNP & Trait & $-\log _{10} P$ \\
\hline \multirow[t]{3}{*}{ chr1:144080083 } & NOIT distance to center, total & 5.969 \\
\hline & NOIT center duration & 4.633 \\
\hline & NOIT distance to center, mean & 5.143 \\
\hline \multirow[t]{3}{*}{ chr4:58009499 } & OFT distance to center, total & 7.254 \\
\hline & OFT distance to center, mean & 7.469 \\
\hline & OFT total travel distance & 4.191 \\
\hline \multirow[t]{3}{*}{ chr4:112234344 } & NOIT center duration & 6.028 \\
\hline & NOIT distance to center, mean & 6.598 \\
\hline & NOIT distance to center, total & 5.975 \\
\hline \multirow[t]{4}{*}{ chr4:118013062 } & OFT center frequency & 5.777 \\
\hline & OFT distance to center, total & 6.099 \\
\hline & OFT center duration & 5.373 \\
\hline & OFT distance to center, mean & 5.001 \\
\hline \multirow[t]{3}{*}{ chr4:150582701 } & SIT distance to social zone, mean & 5.884 \\
\hline & SIT distance to social zone, total & 5.788 \\
\hline & SIT in social zone duration & 4.324 \\
\hline \multirow[t]{3}{*}{ chr4:151128675 } & SIT in social zone duration & 5.820 \\
\hline & SIT distance to social zone mean & 4.351 \\
\hline & SIT distance to social zone, total & 4.366 \\
\hline \multirow[t]{2}{*}{ chr4:156801420 } & NOIT distance to center, total & 5.622 \\
\hline & NOIT distance to center, mean & 4.543 \\
\hline \multirow[t]{4}{*}{ chr6:119975012 } & NOIT distance to center, mean & 5.692 \\
\hline & NOIT center frequency & 4.275 \\
\hline & NOIT distance to center, total & 5.542 \\
\hline & NOIT total travel distance & 5.270 \\
\hline \multirow[t]{4}{*}{ chr6:120117521 } & NOIT total travel distance & 5.640 \\
\hline & NOIT center frequency & 4.330 \\
\hline & NOIT distance to center, mean & 5.021 \\
\hline & NOIT distance to center, total & 4.961 \\
\hline \multirow[t]{3}{*}{ chr11:33359859 } & OFT total travel distance & 8.268 \\
\hline & OFT center duration & 4.125 \\
\hline & OFT center frequency & 4.895 \\
\hline \multirow[t]{3}{*}{$\operatorname{chr} 14: 44904830$} & OFT distance to center, total & 5.741 \\
\hline & OFT center frequency & 4.189 \\
\hline & OFT distance to center, mean & 5.096 \\
\hline \multirow[t]{2}{*}{ chr14:41727329 } & SIT total travel distance & 5.627 \\
\hline & NOIT total travel distance & 4.291 \\
\hline \multirow[t]{2}{*}{ chr19:20666789 } & SIT distance to object zone, mean & 6.746 \\
\hline & SIT distance to object zone, total & 6.613 \\
\hline \multirow[t]{2}{*}{ chr19:20667417 } & SIT distance to object zone, total & 6.619 \\
\hline & SIT distance to object zone, mean & 6.732 \\
\hline \multirow[t]{2}{*}{ chr19:55339863 } & SIT distance to social zone, mean & 6.661 \\
\hline & SIT distance to social zone, total & 6.643 \\
\hline
\end{tabular}




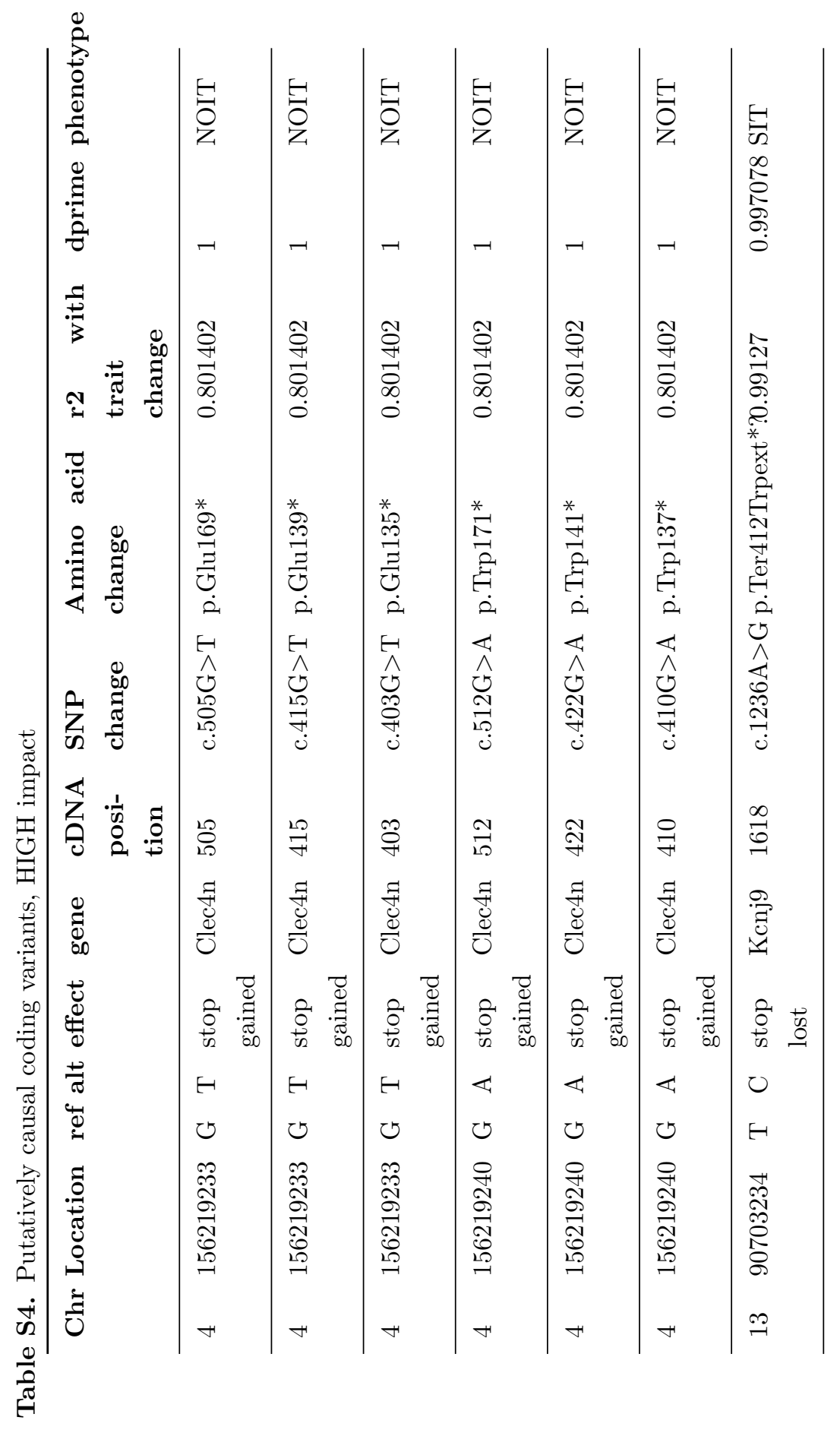




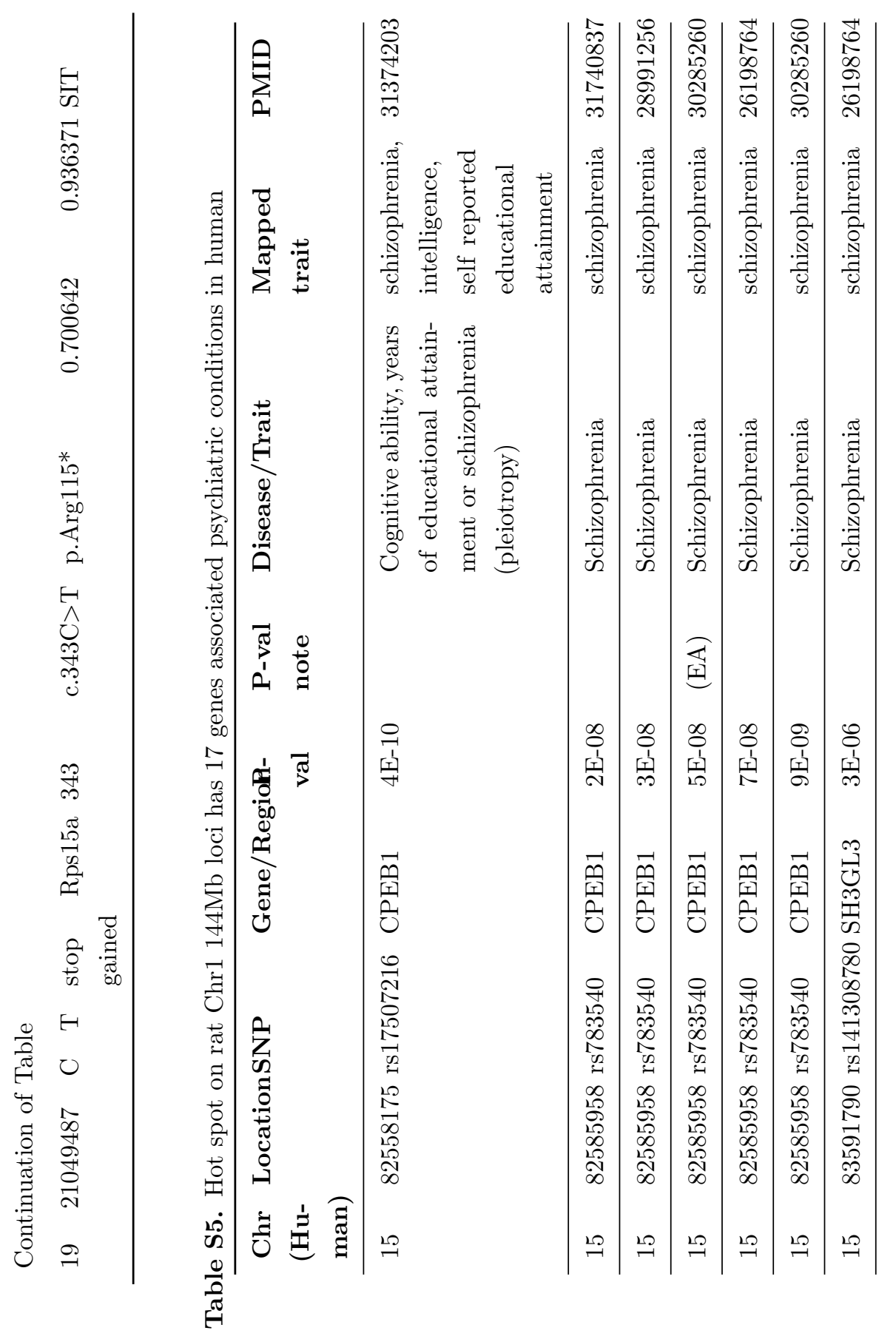




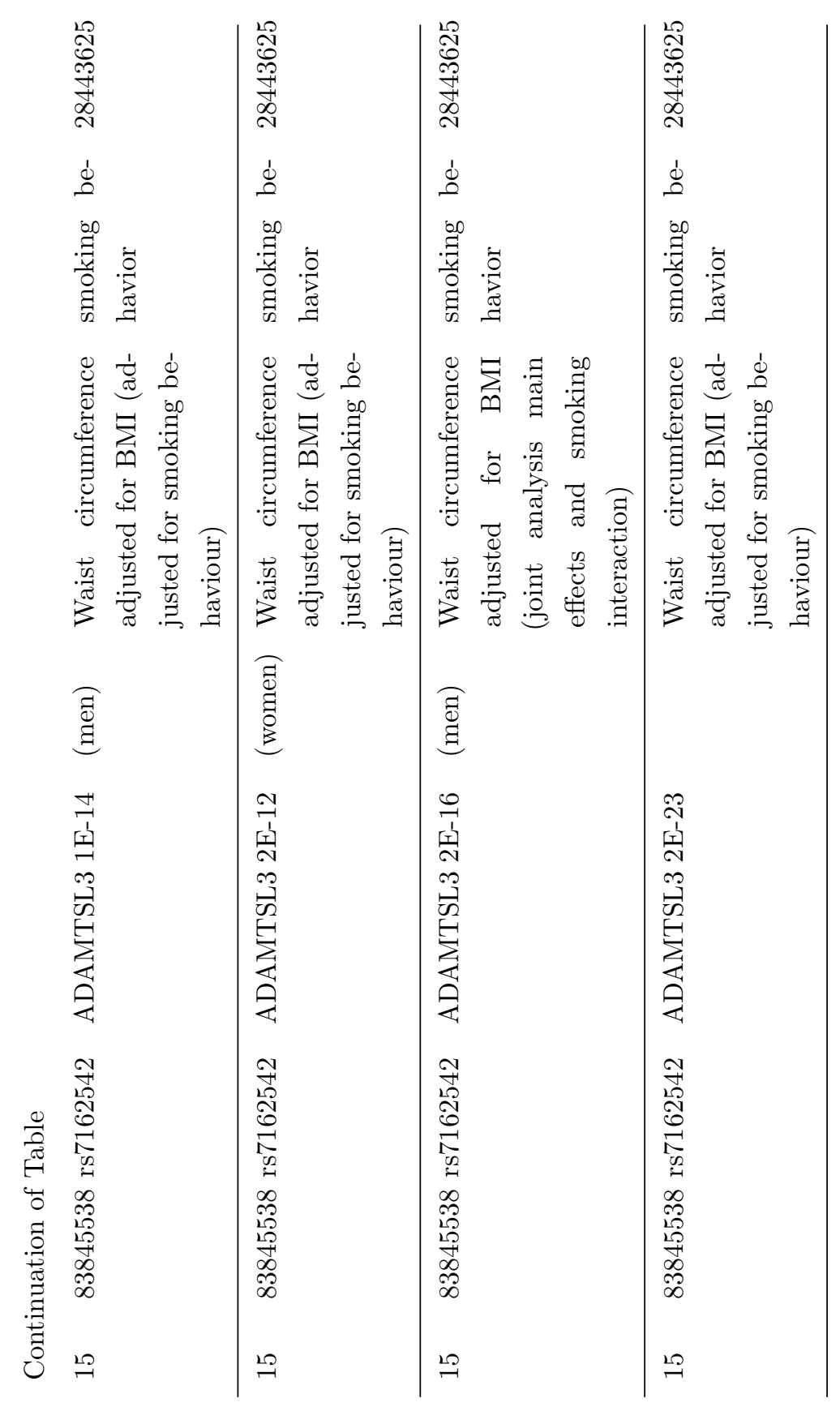




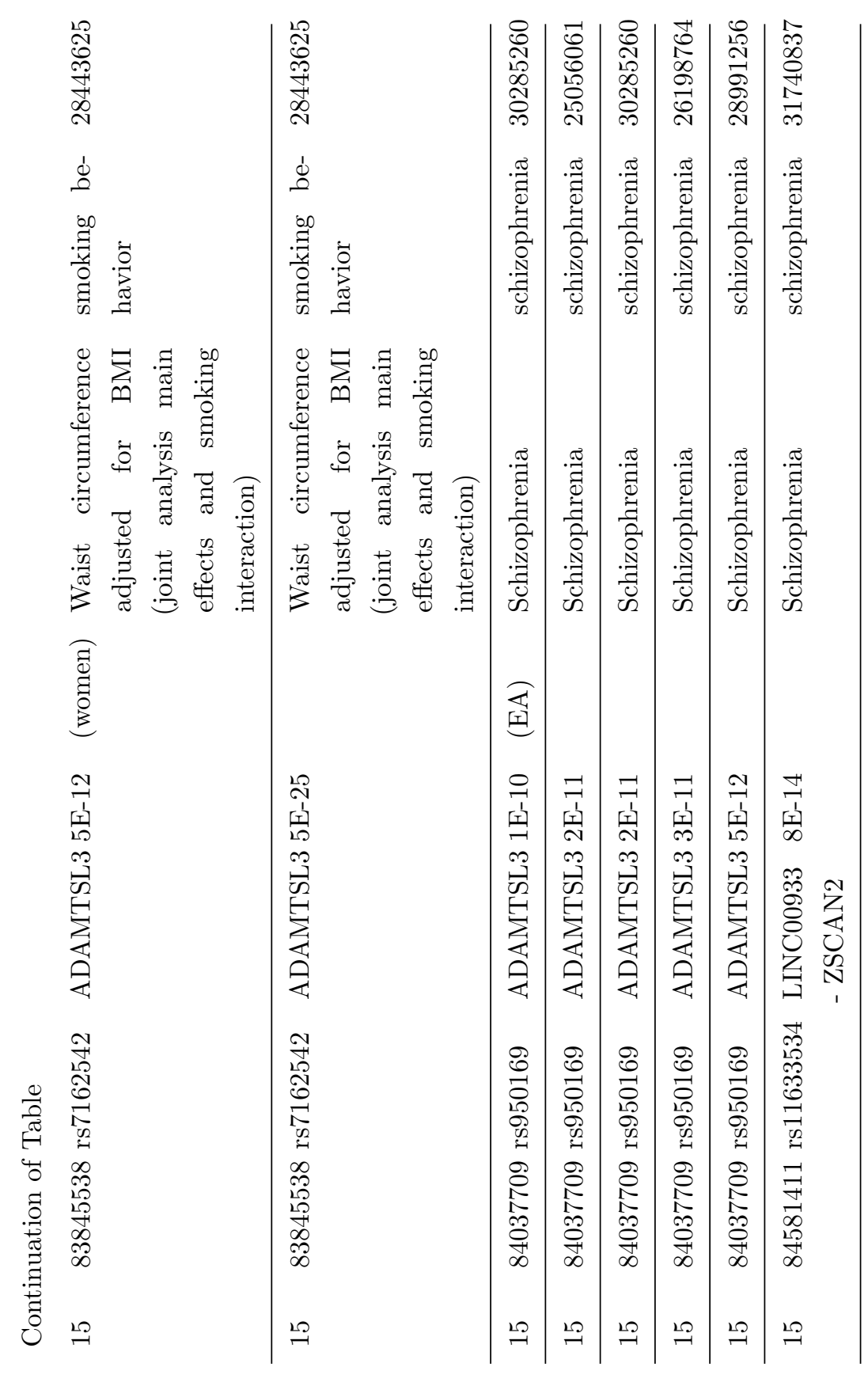




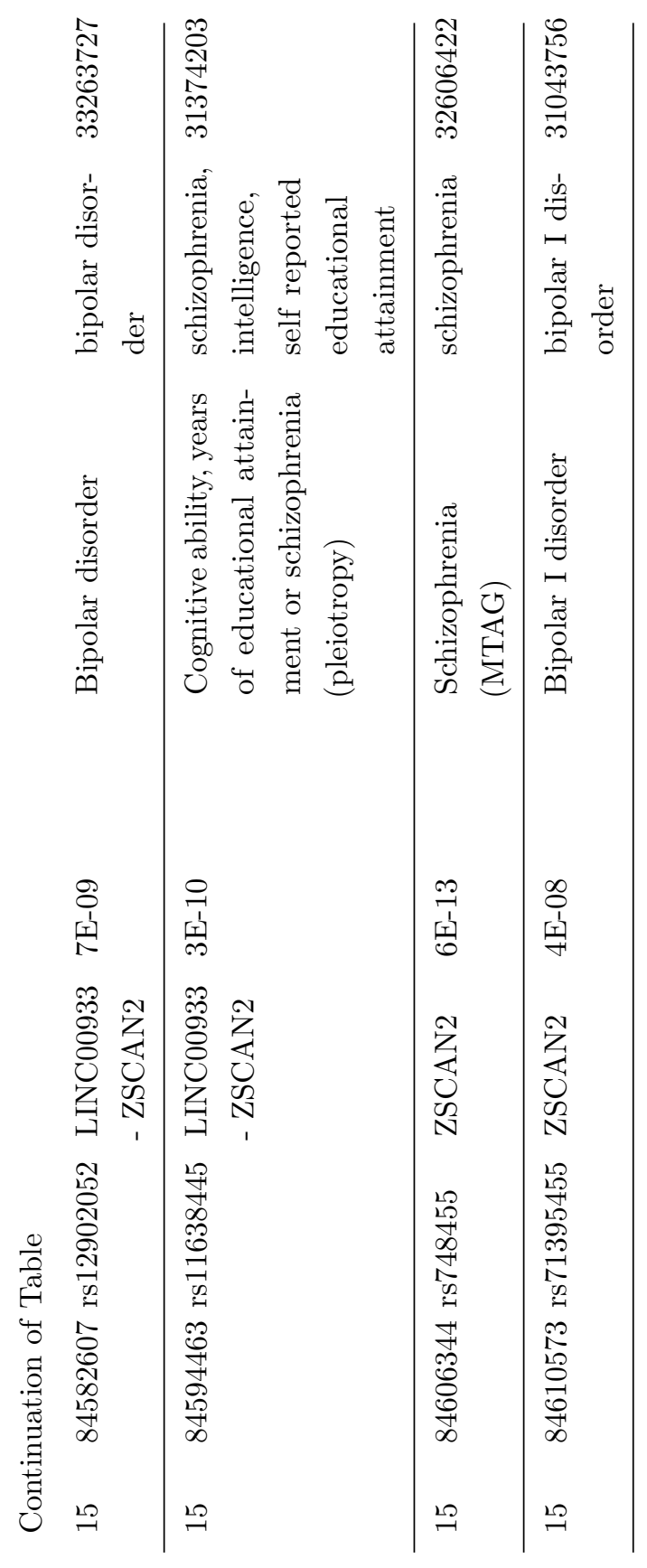


$\infty$
$\stackrel{N}{0}$
10
$\infty$
$\infty$
$\infty$

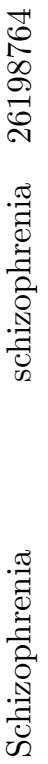

$\frac{7}{\square}$

0
1
$\frac{1}{10}$

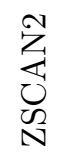

।

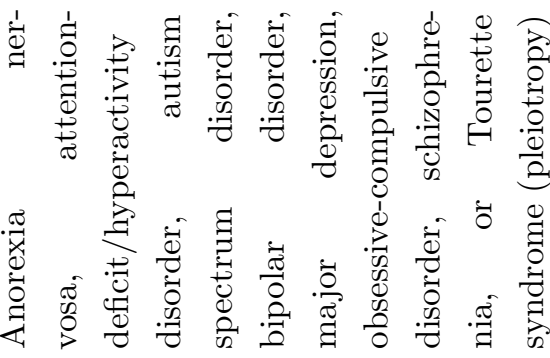

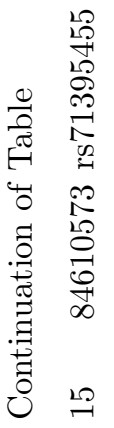




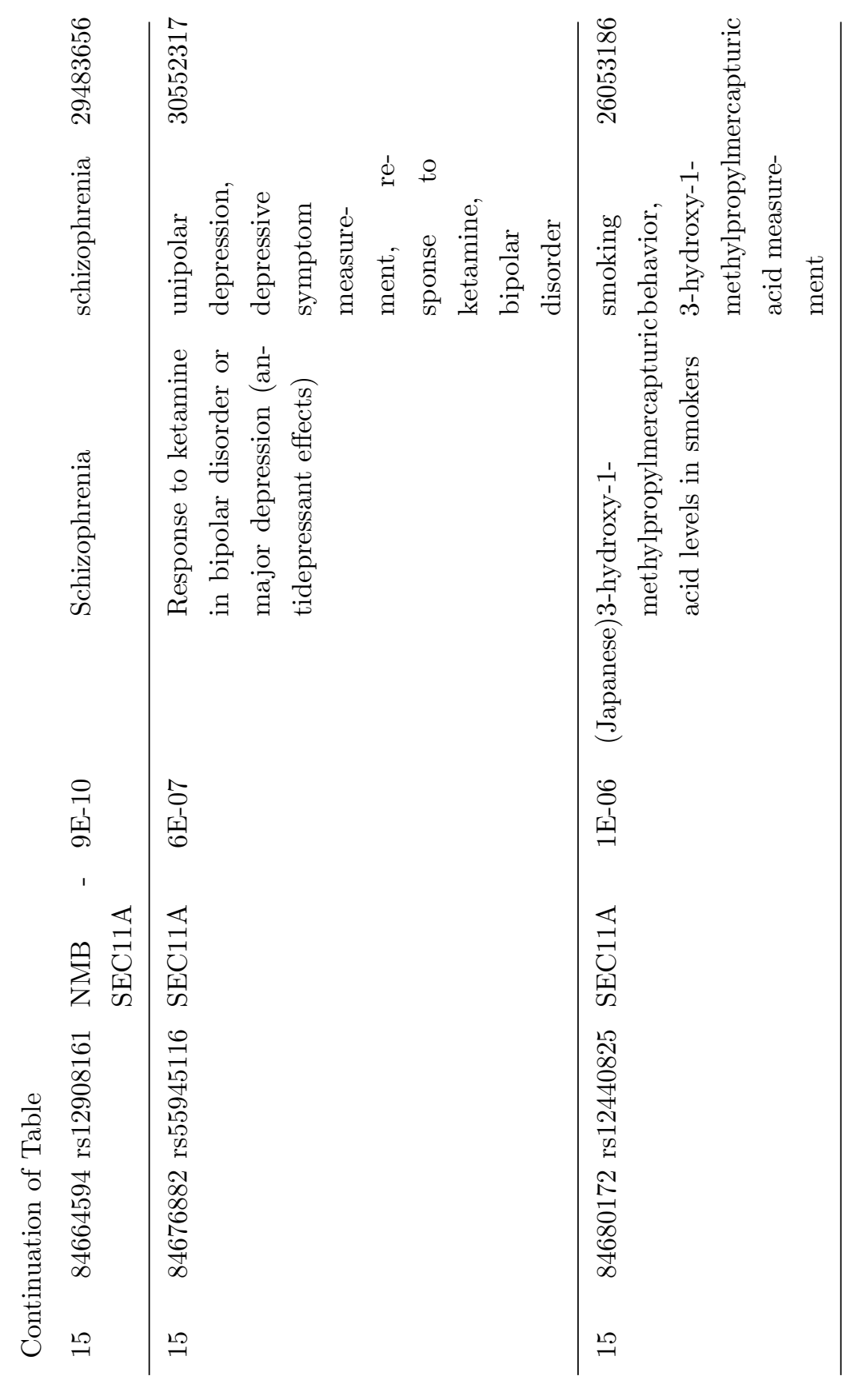


bioRxiv preprint doi: https://doi.org/10.1101/2021.10.18.464872; this version posted October 19,2021 . The copyright holder for this preprint (which was not certified by peer review) is the author/funder, who has granted bioRxiv a license to display the preprint in perpetuity. It is made available under aCC-BY 4.0 International license.

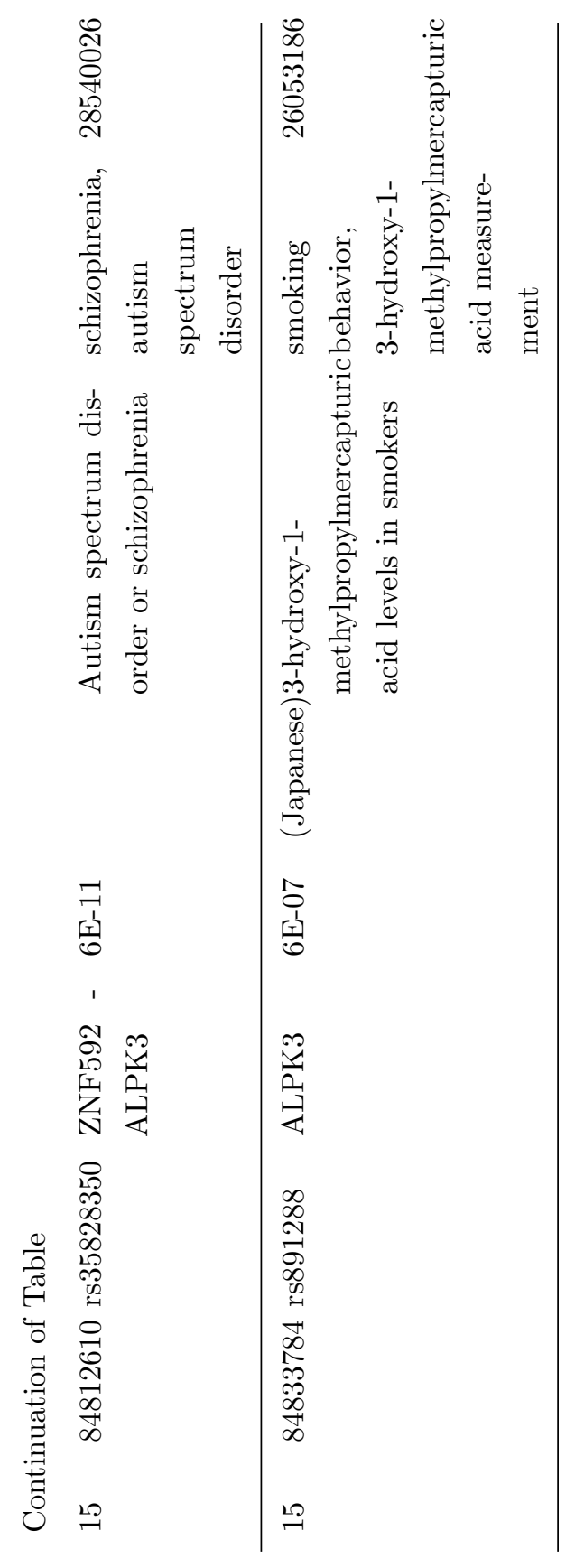




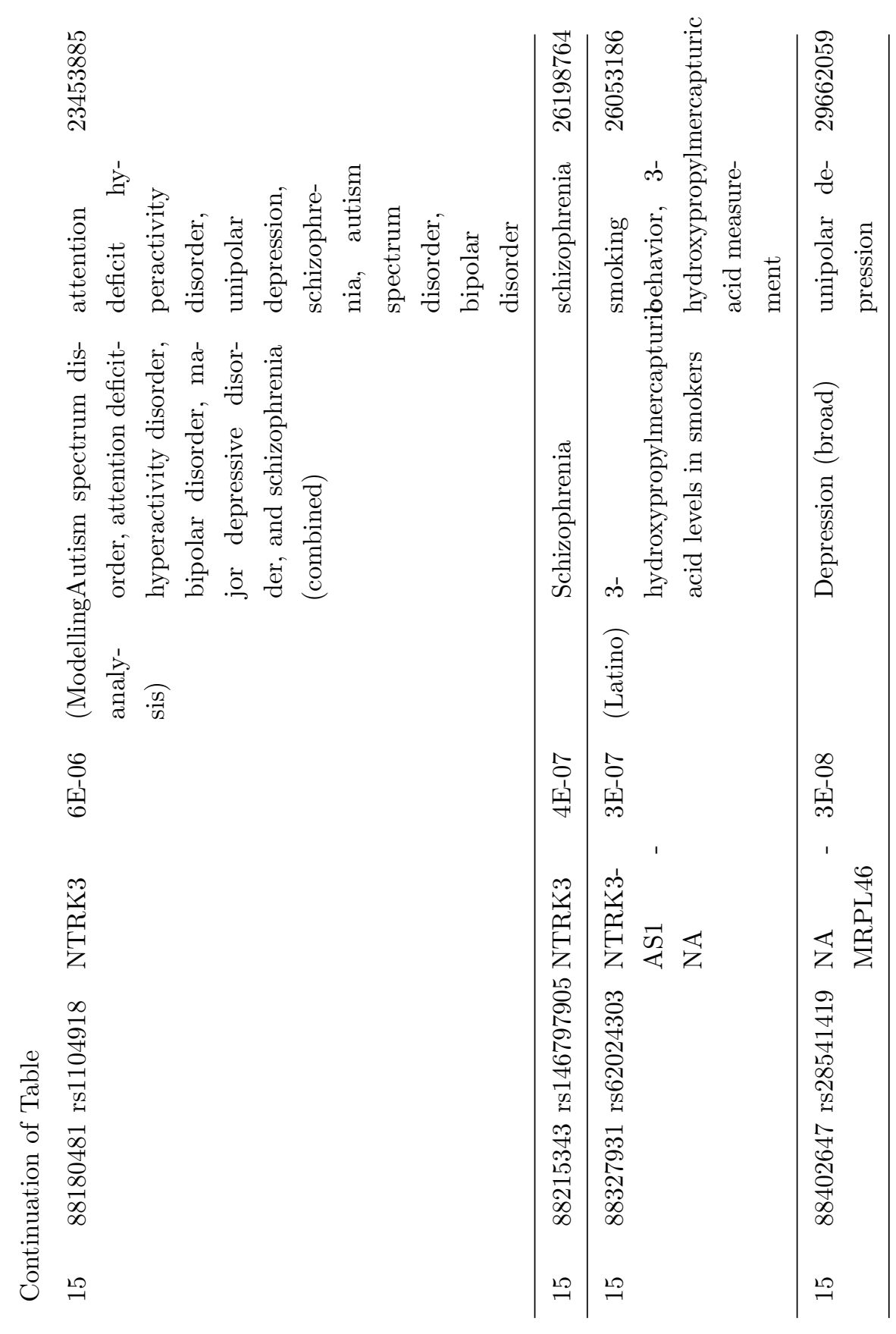




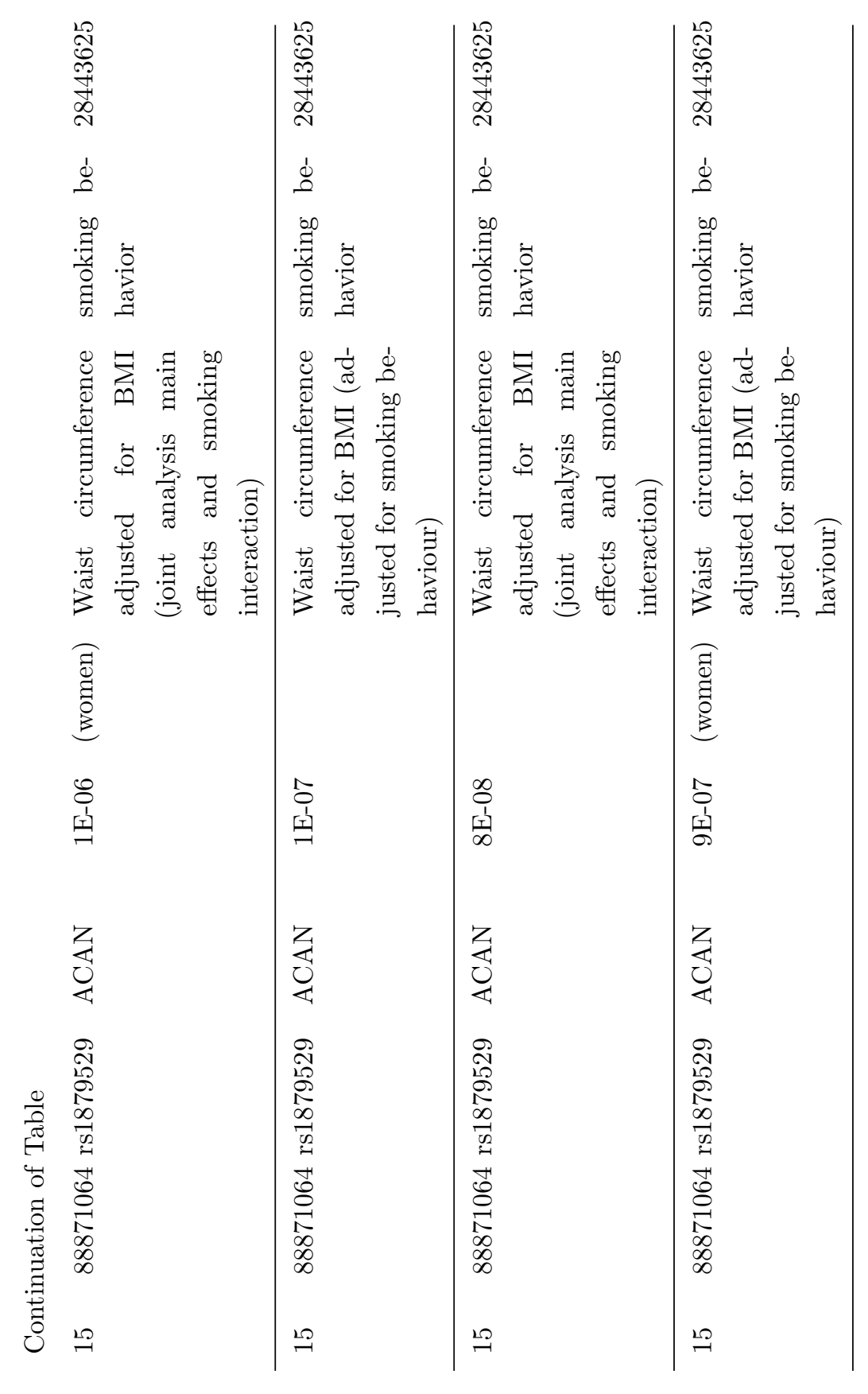




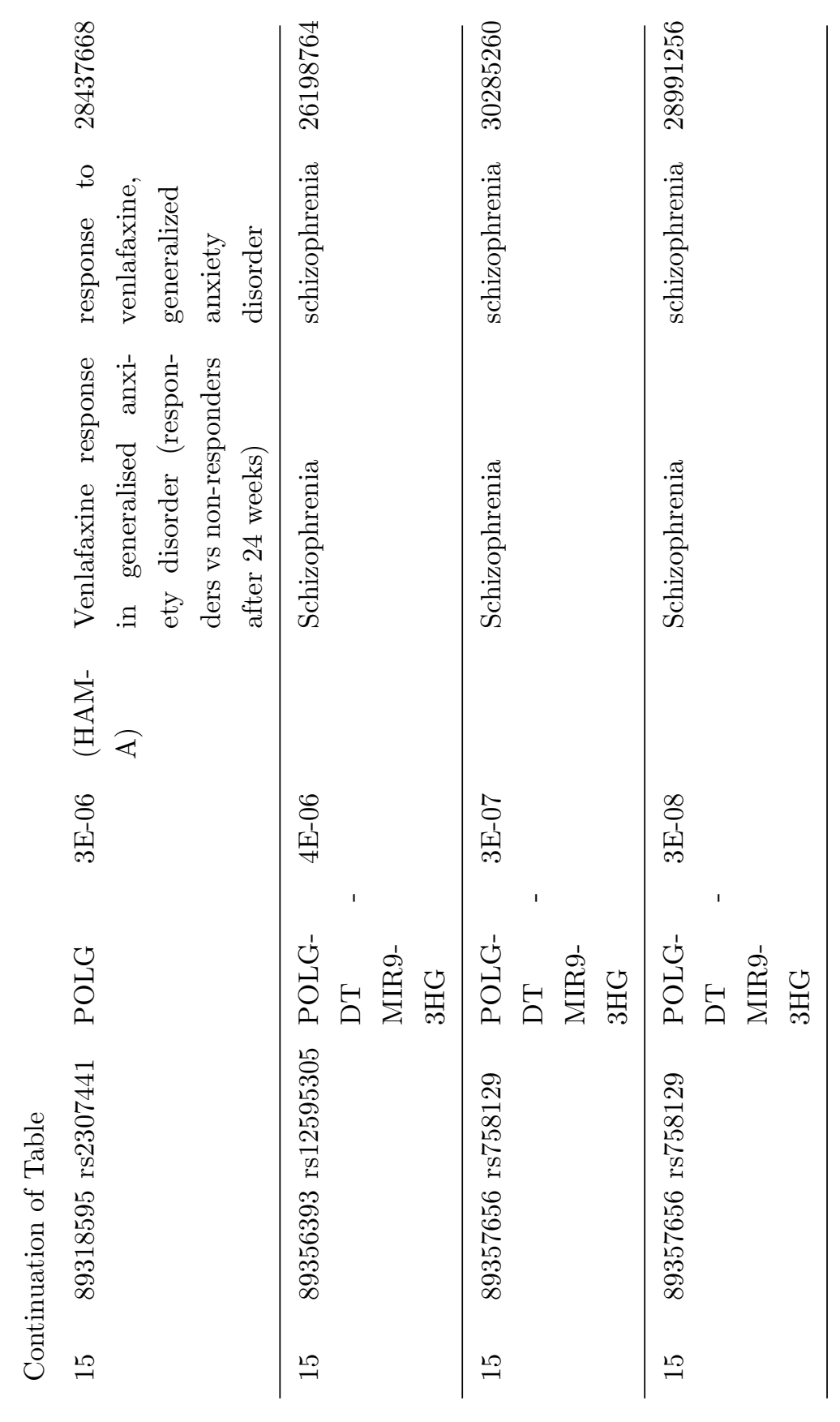




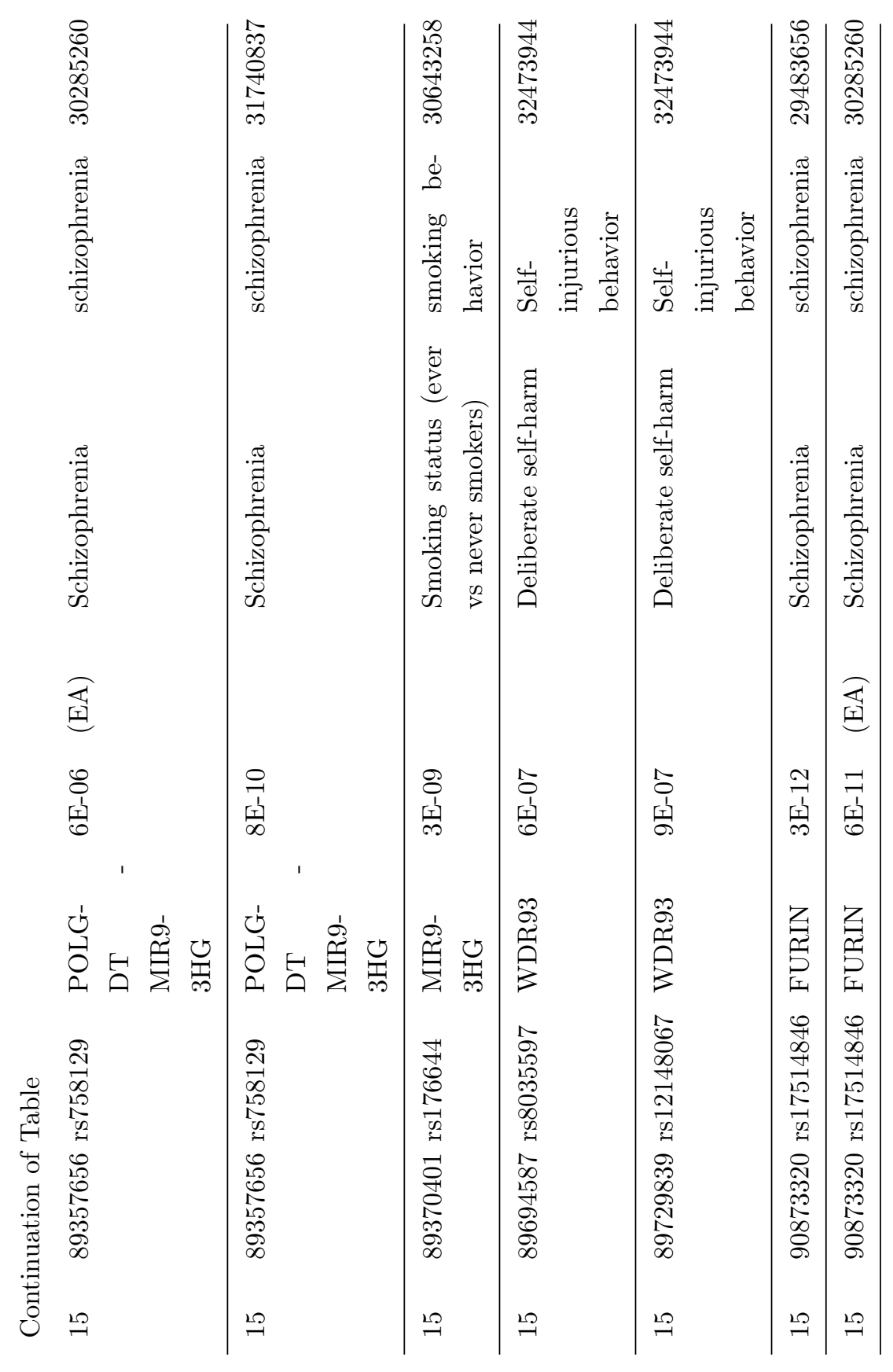


bioRxiv preprint doi: https://doi.org/10.1101/2021.10.18.464872; this version posted October 19,2021 . The copyright holder for this preprint (which was not certified by peer review) is the author/funder, who has granted bioRxiv a license to display the preprint in perpetuity. It is made available under aCC-BY 4.0 International license.

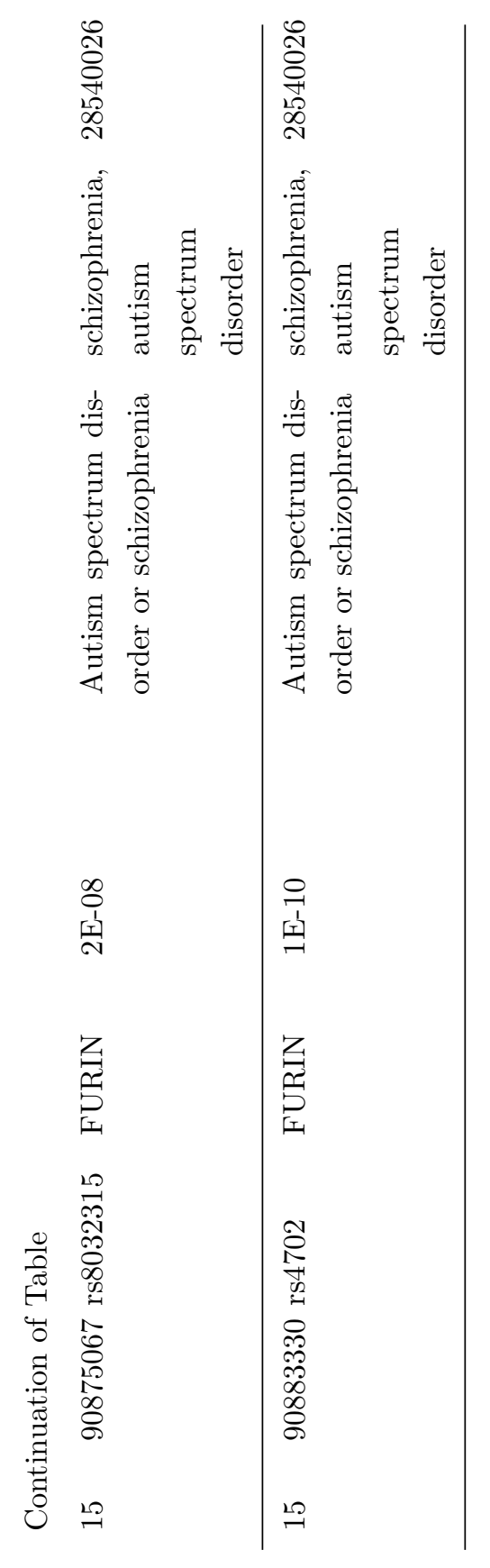


$\infty$
$\stackrel{N}{D}$
10
$\infty$
$\infty$
$\infty$

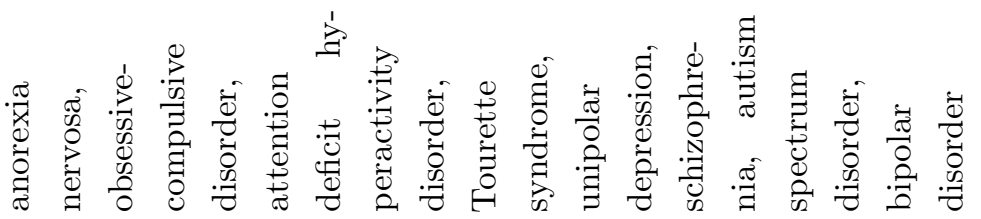

국
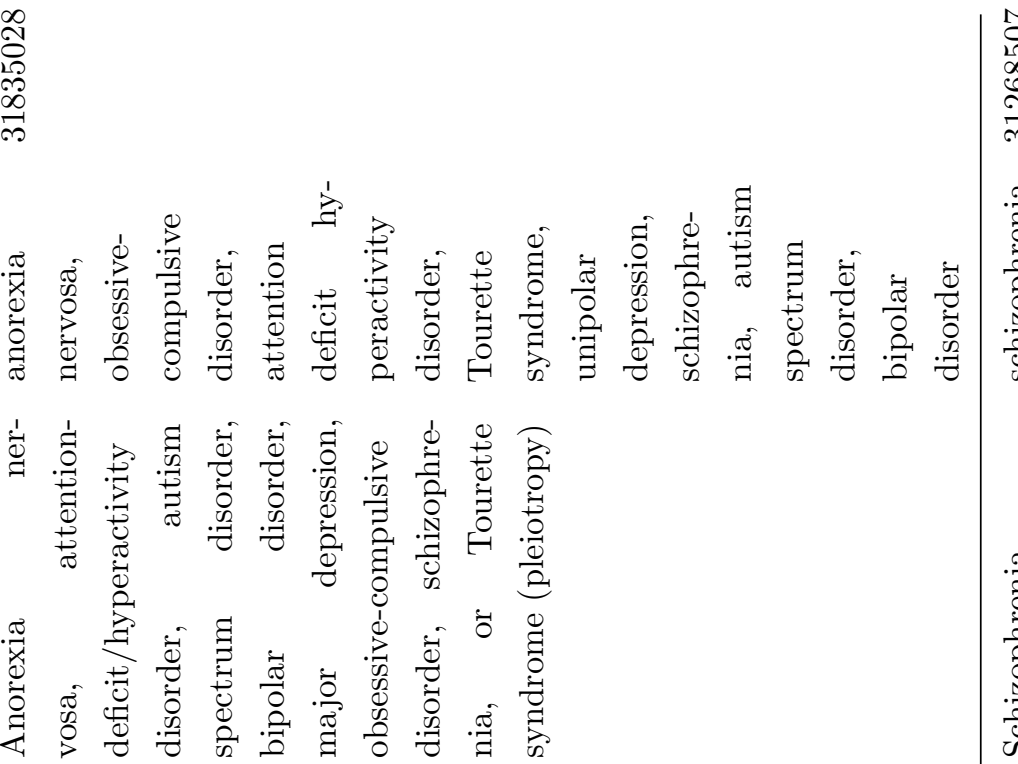

点 


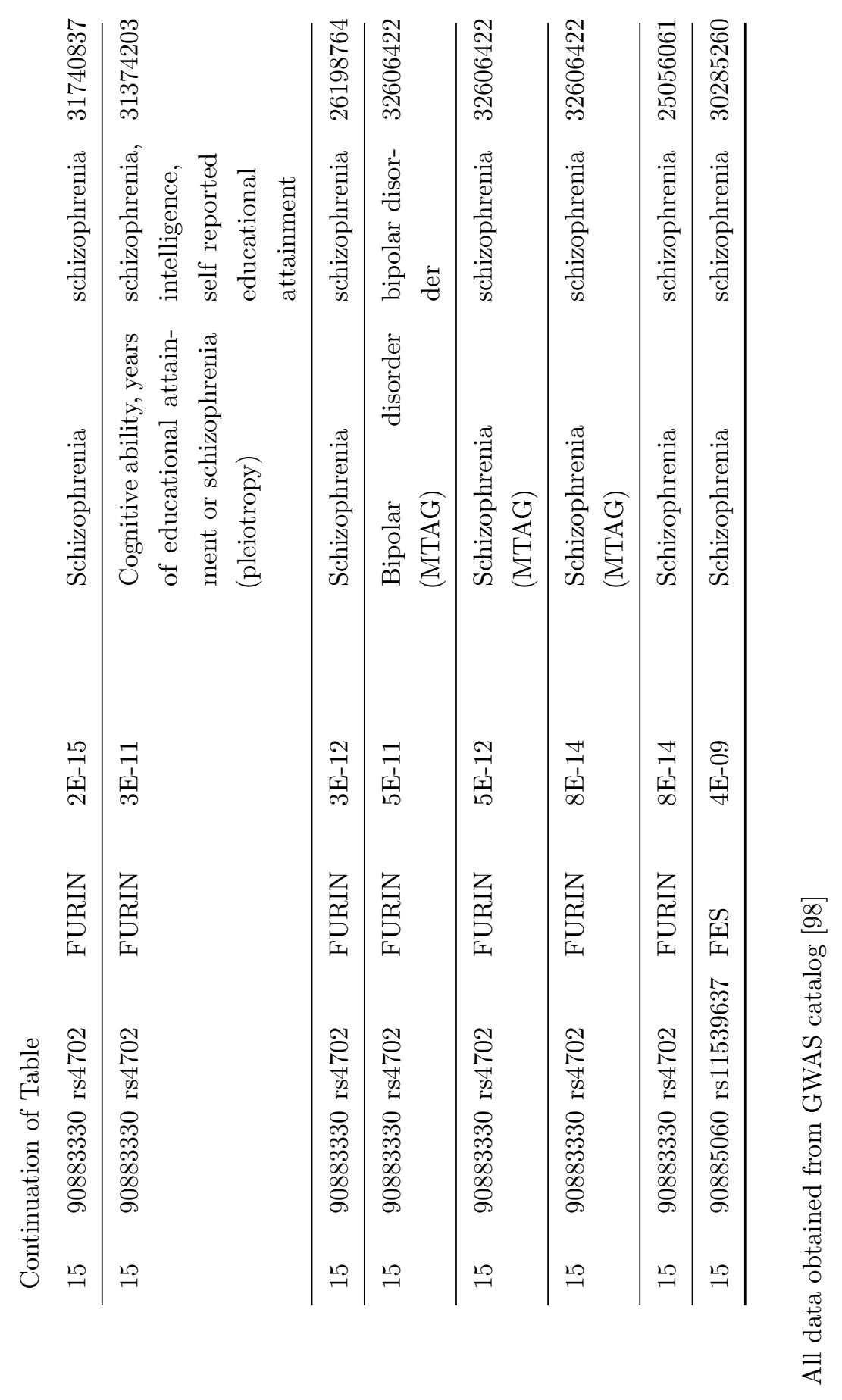




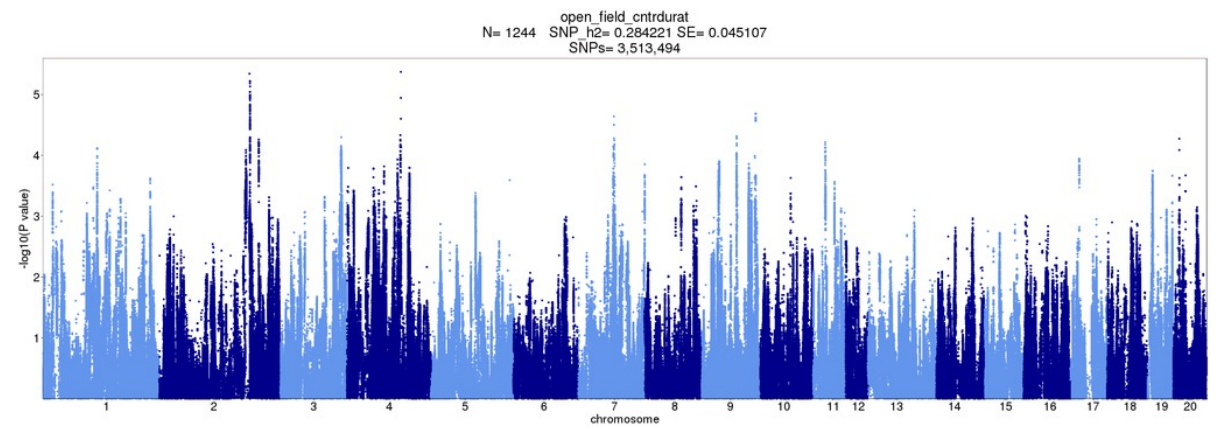

Figure S1: OFT GWAS: Duration in center zone, mean

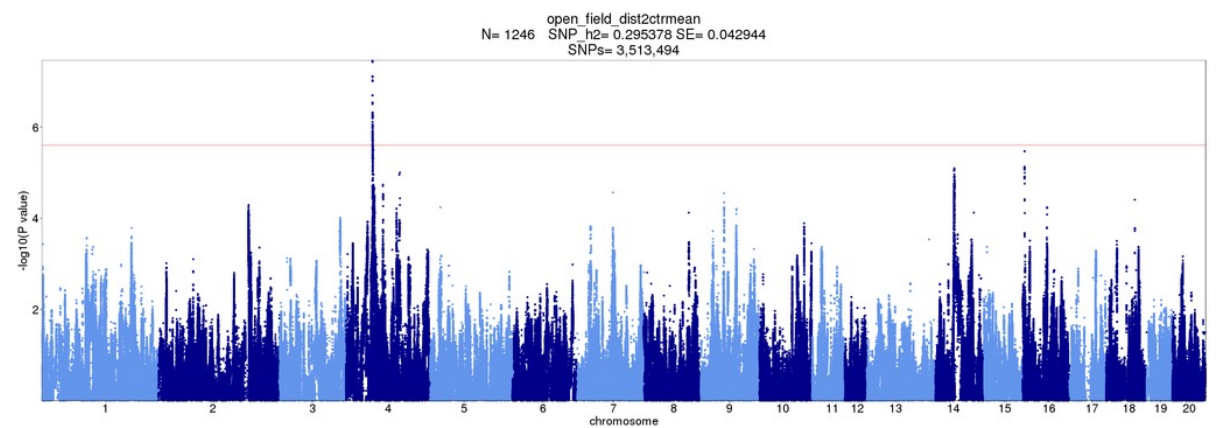

Figure S2: OFT GWAS: Mean distance to center zone

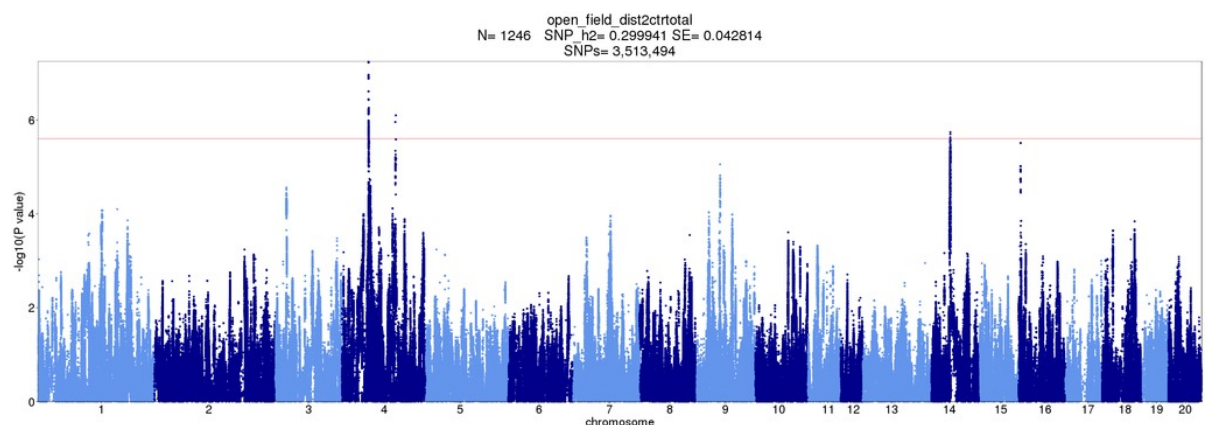

Figure S3: OFT GWAS: Total distance to center zone 


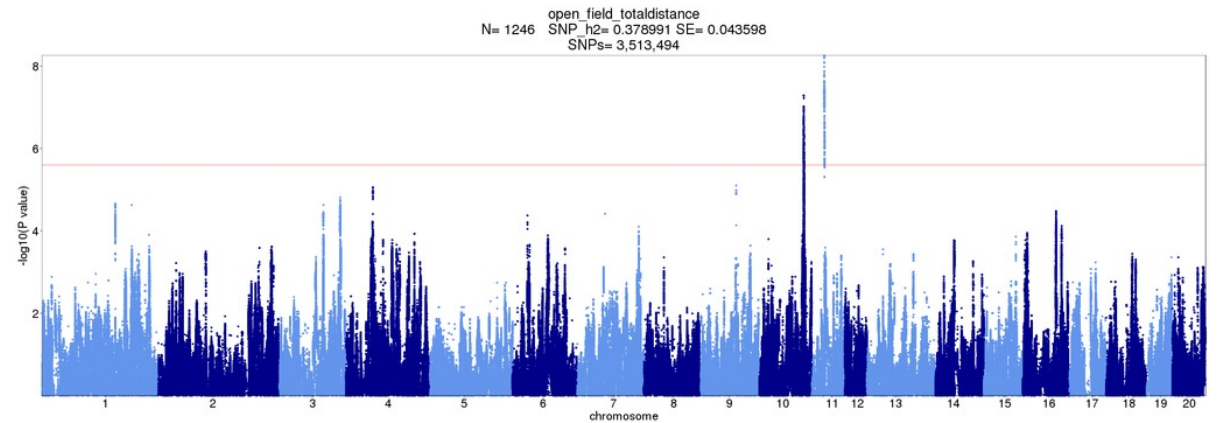

Figure S4: OFT GWAS: Total travel distance

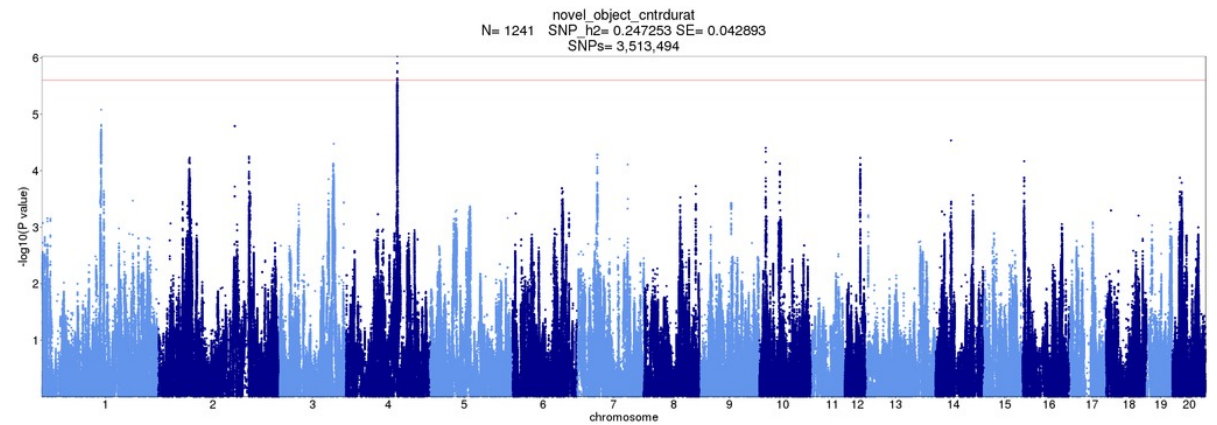

Figure S5: NOIT GWAS: Duration in center zone

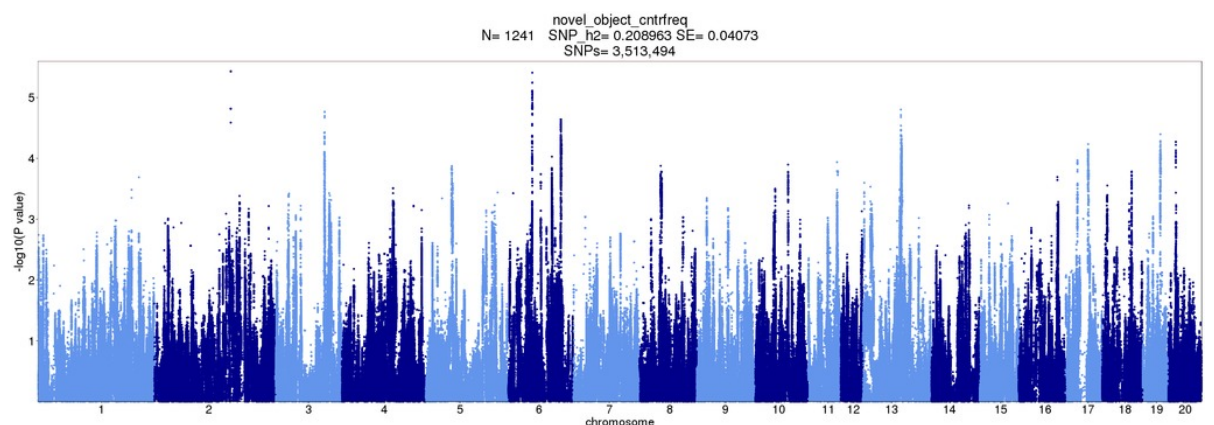

Figure S6: NOIT GWAS: Frequency of entering center zone 


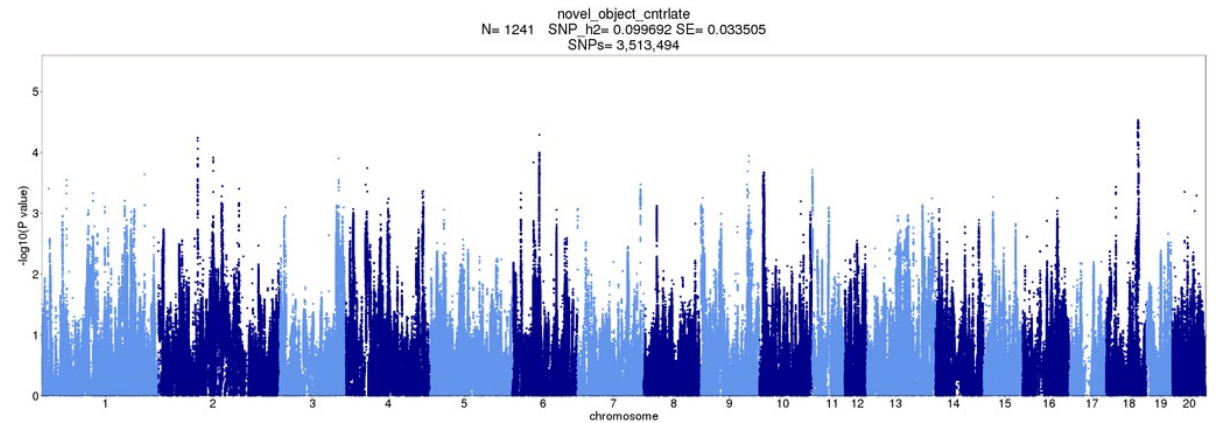

Figure S7: NOIT GWAS: Latency of entering center zone

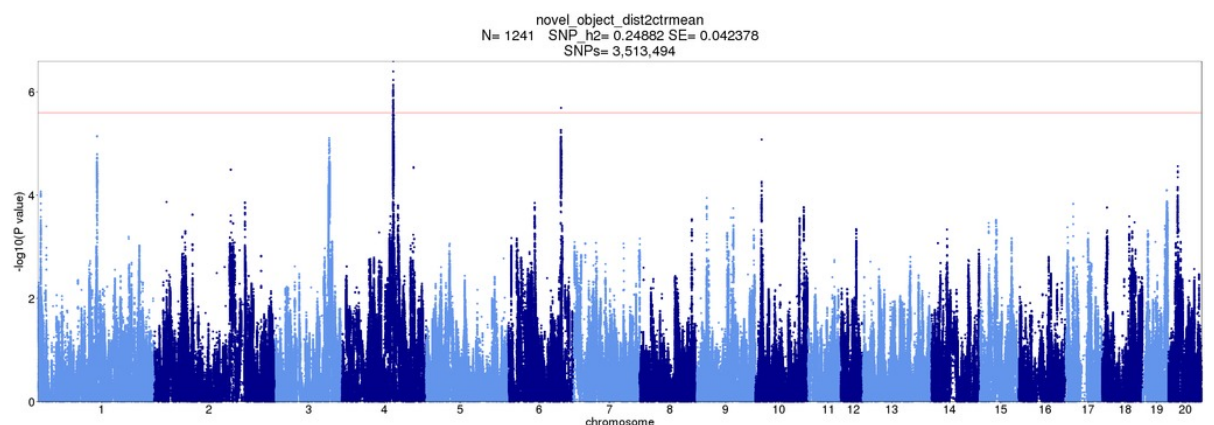

Figure S8: NOIT GWAS: Mean distance to center zone

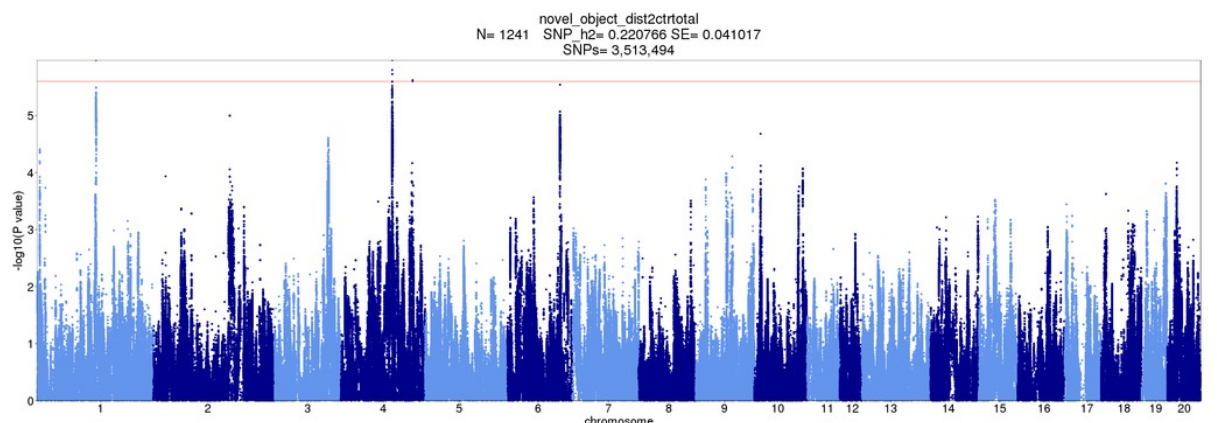

Figure S9: NOIT GWAS: Total distance to center zone 


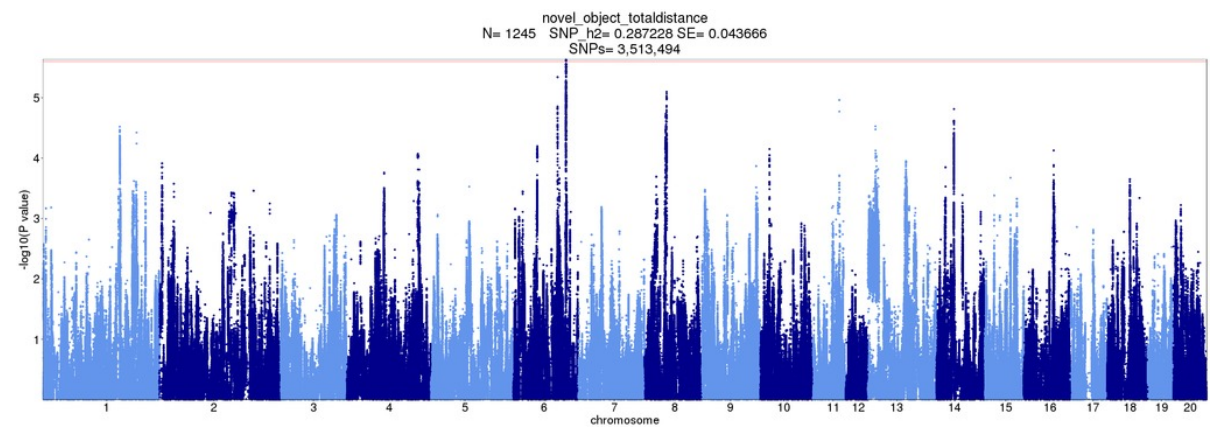

Figure S10: NOIT GWAS: Total travel distance

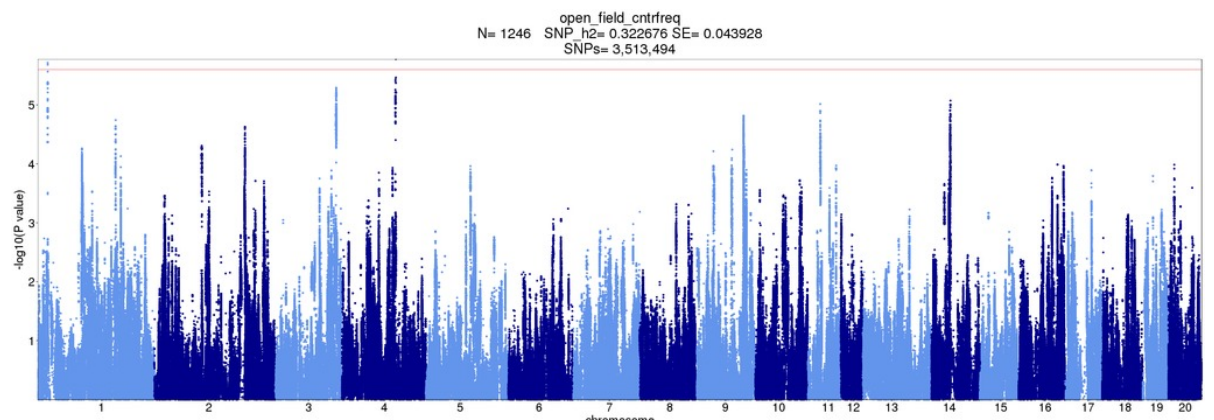

Figure S11: NOIT GWAS: Frequency of entering center zone, mean

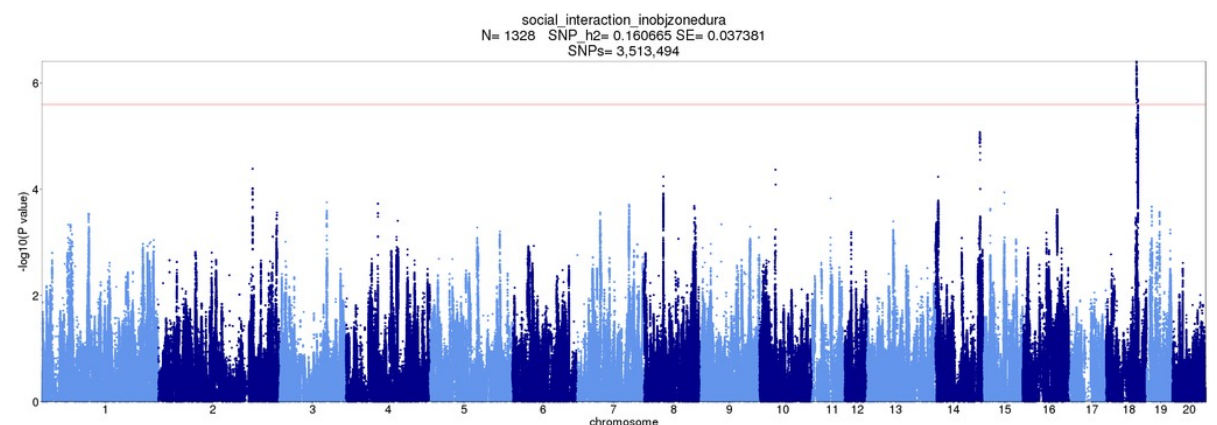

Figure S12: SIT GWAS: Duration in object zone 


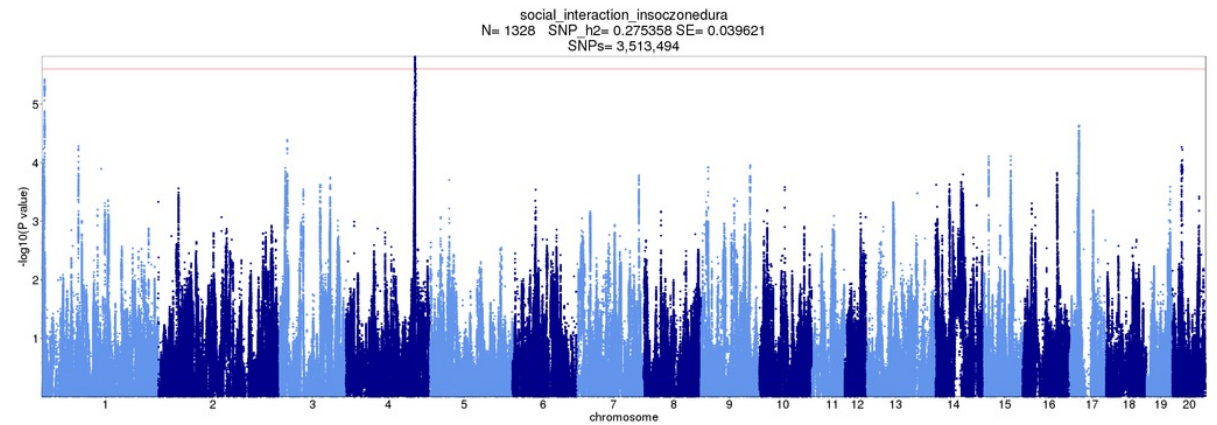

Figure S13: SIT GWAS: Duration in social zone

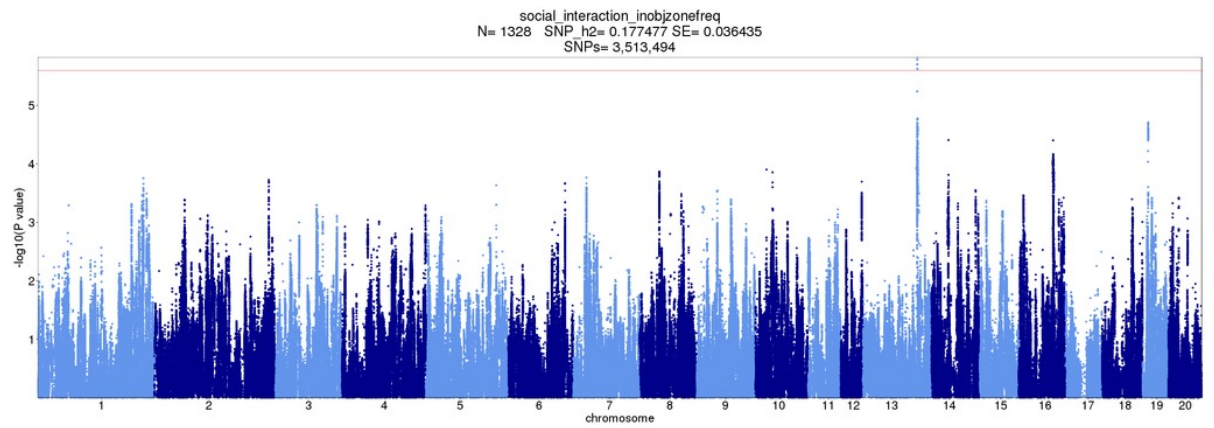

Figure S14: SIT GWAS: Frequency of entering object zone

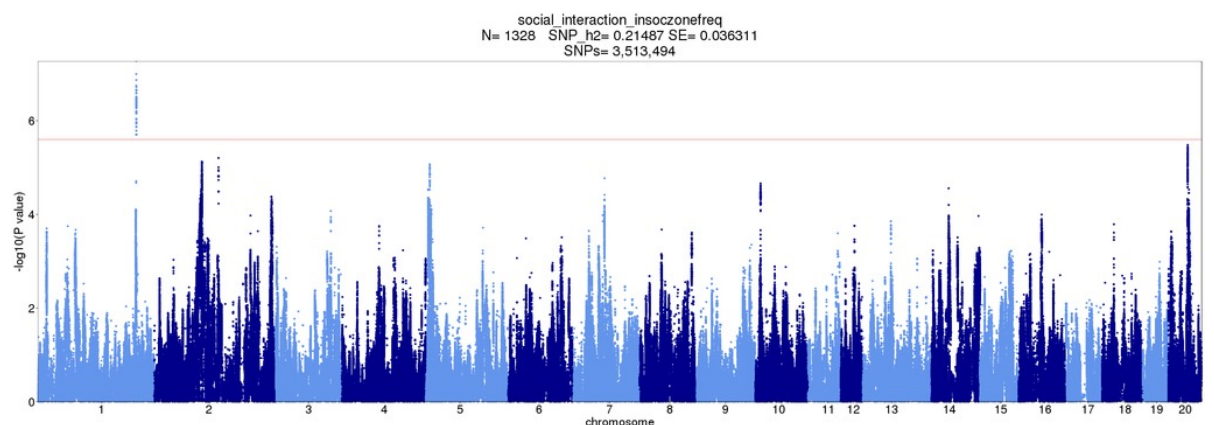

Figure S15: SIT GWAS: Frequency of entering social zone 


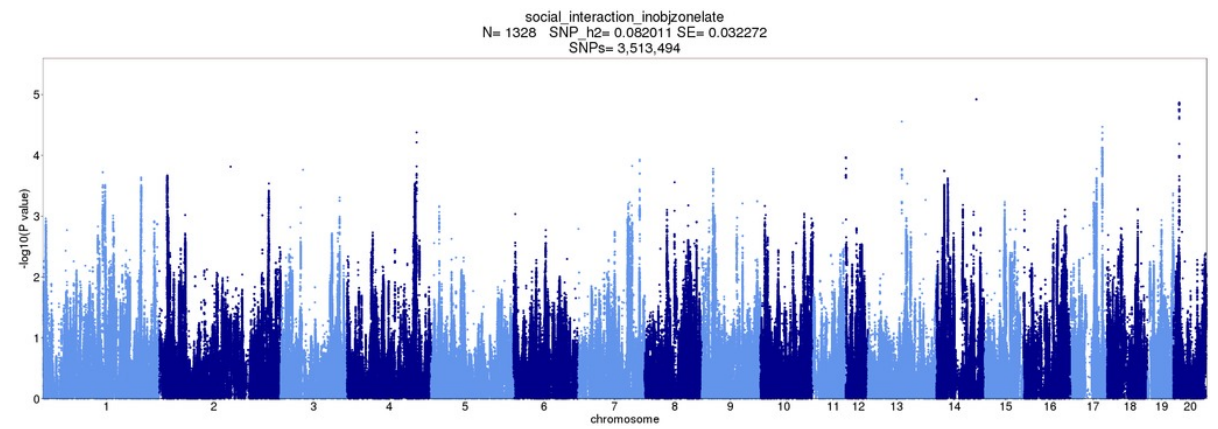

Figure S16: SIT GWAS: Latency of entering object zone

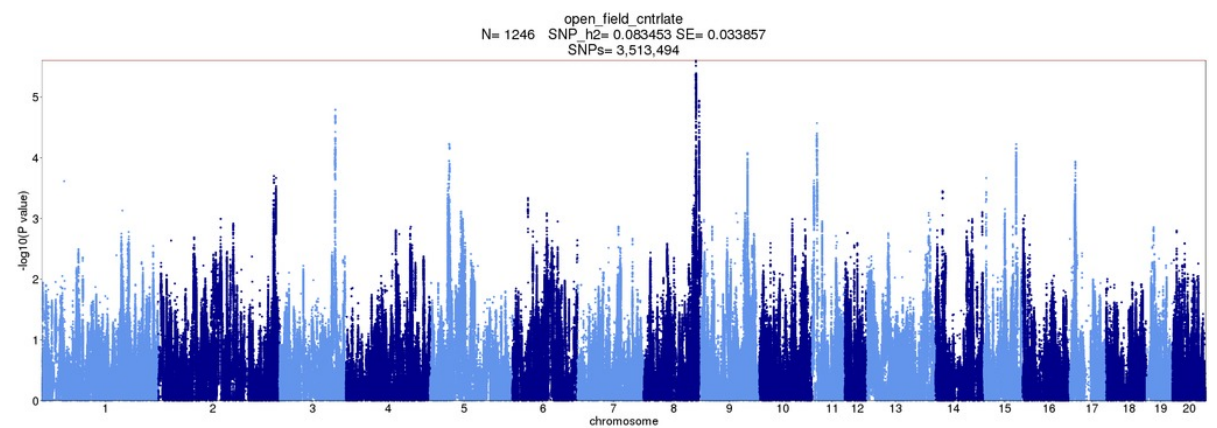

Figure S17: SIT GWAS: Latency of entering center zone, mean

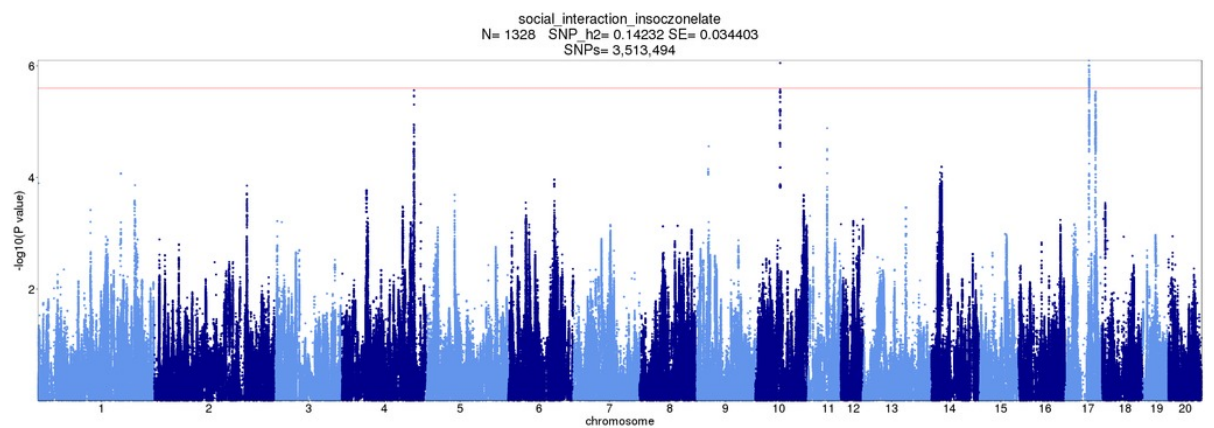

Figure S18: SIT GWAS: Latency of entering social zone 


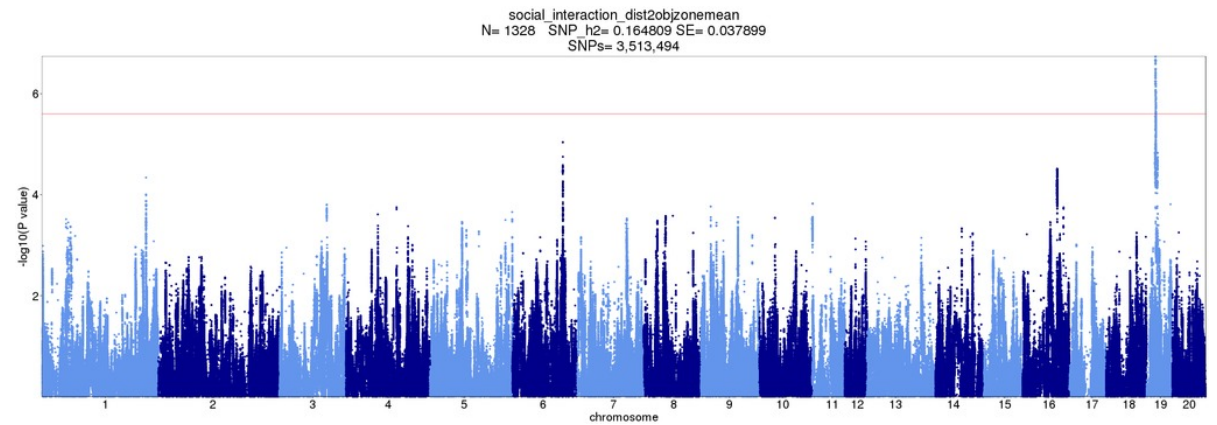

Figure S19: SIT GWAS: Mean distance to object zone

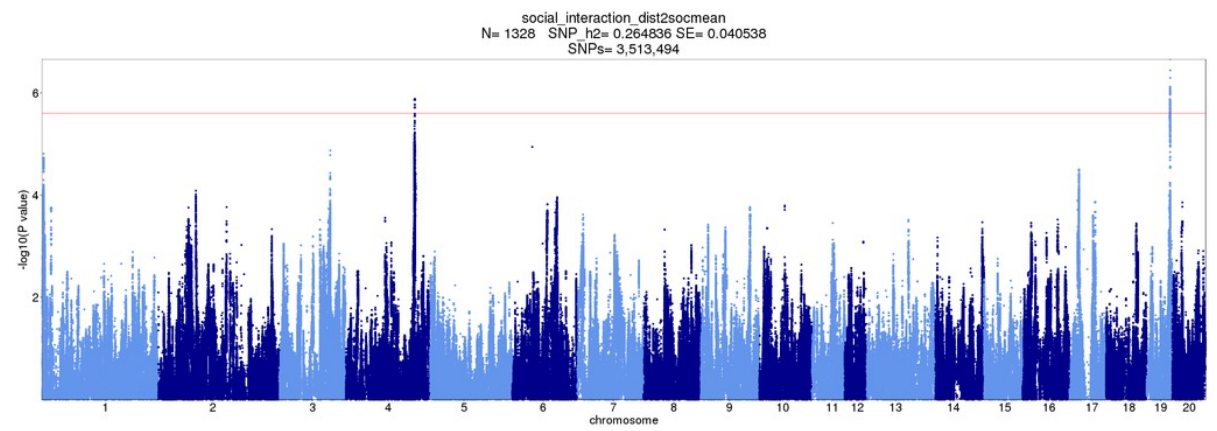

Figure S20: SIT GWAS: Mean distance to social zone

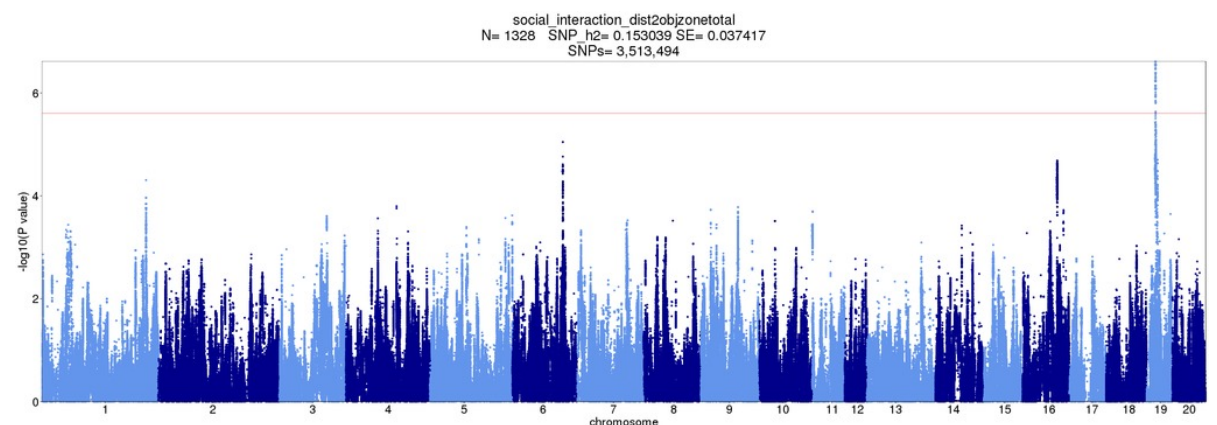

Figure S21: SIT GWAS: Total distance to object zone 


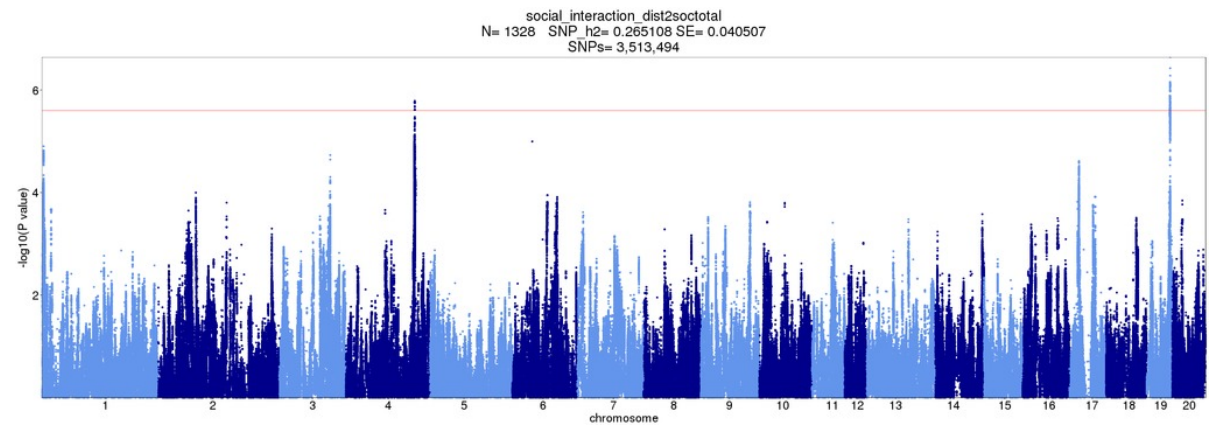

Figure S22: SIT GWAS: Total distance to social zone

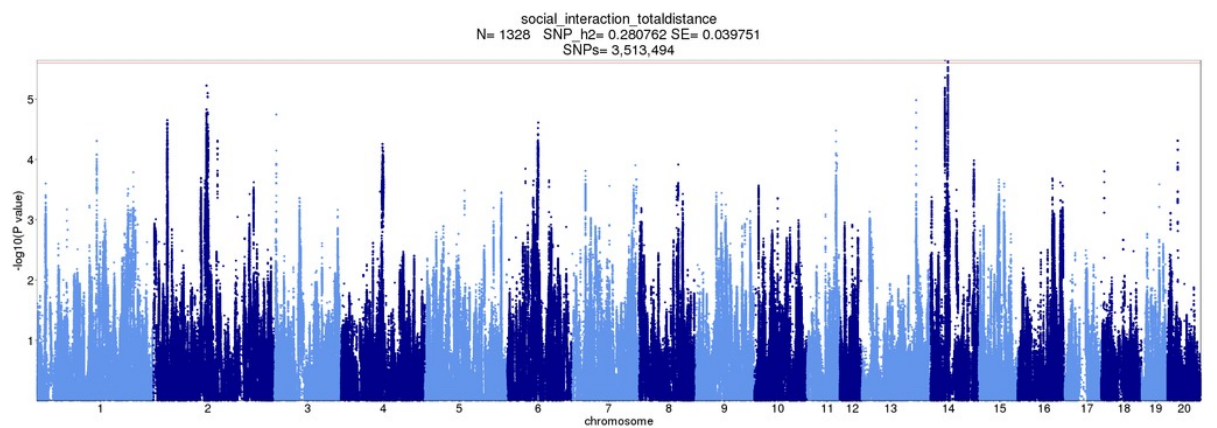

Figure S23: SIT GWAS: Total travel distance 
bioRxiv preprint doi: https://doi.org/10.1101/2021.10.18.464872; this version posted October 19, 2021. The copyright holder for this preprint (which was not certified by peer review) is the author/funder, who has granted bioRxiv a license to display the preprint in perpetuity. It is made available under aCC-BY 4.0 International license.

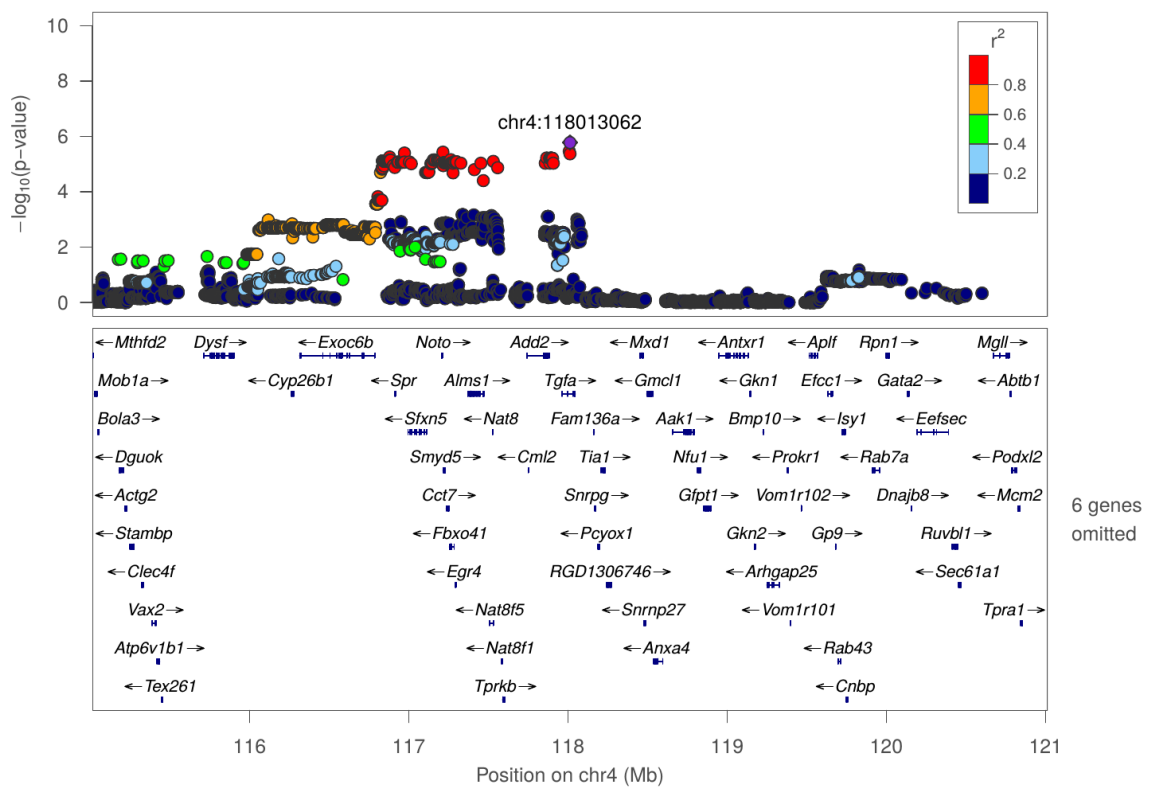

Figure S24: Regional association plot for OFT: Frequency of entering center zone at chr4:118013062 
bioRxiv preprint doi: https://doi.org/10.1101/2021.10.18.464872; this version posted October 19, 2021. The copyright holder for this preprint (which was not certified by peer review) is the author/funder, who has granted bioRxiv a license to display the preprint in perpetuity. It is made available under aCC-BY 4.0 International license.

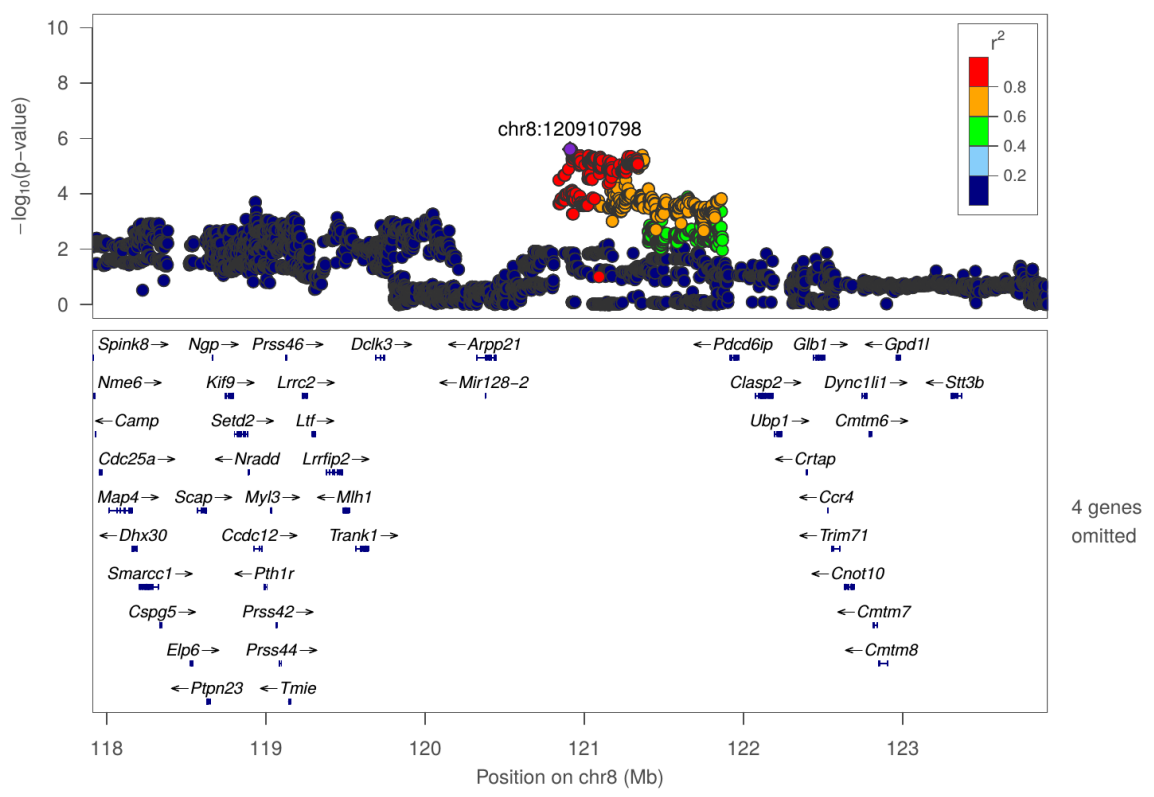

Figure S25: Regional association plot for OFT: Latency of entering center zone at chr8:120910798 
bioRxiv preprint doi: https://doi.org/10.1101/2021.10.18.464872; this version posted October 19, 2021. The copyright holder for this preprint (which was not certified by peer review) is the author/funder, who has granted bioRxiv a license to display the preprint in perpetuity. It is made available under aCC-BY 4.0 International license.

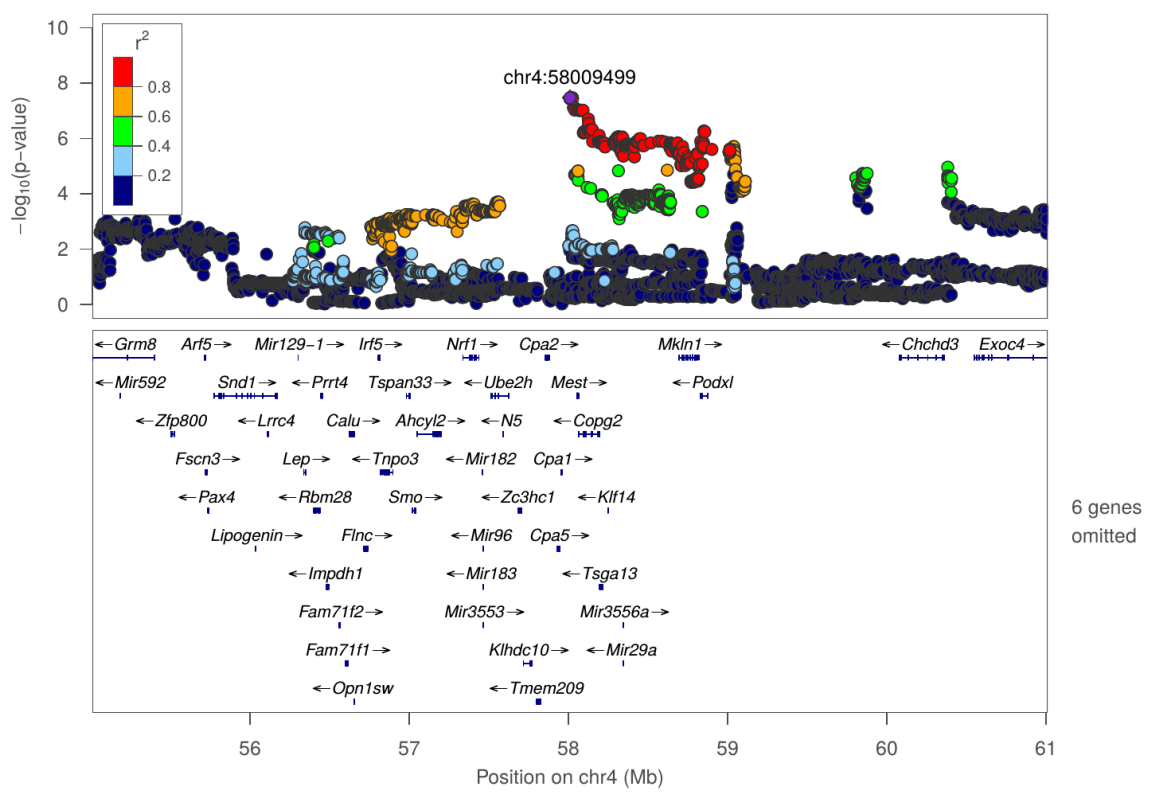

Figure S26: Regional association plot for OFT: Mean distance to center zone at chr4:58009499 
bioRxiv preprint doi: https://doi.org/10.1101/2021.10.18.464872; this version posted October 19, 2021. The copyright holder for this preprint (which was not certified by peer review) is the author/funder, who has granted bioRxiv a license to display the preprint in perpetuity. It is made available under aCC-BY 4.0 International license.

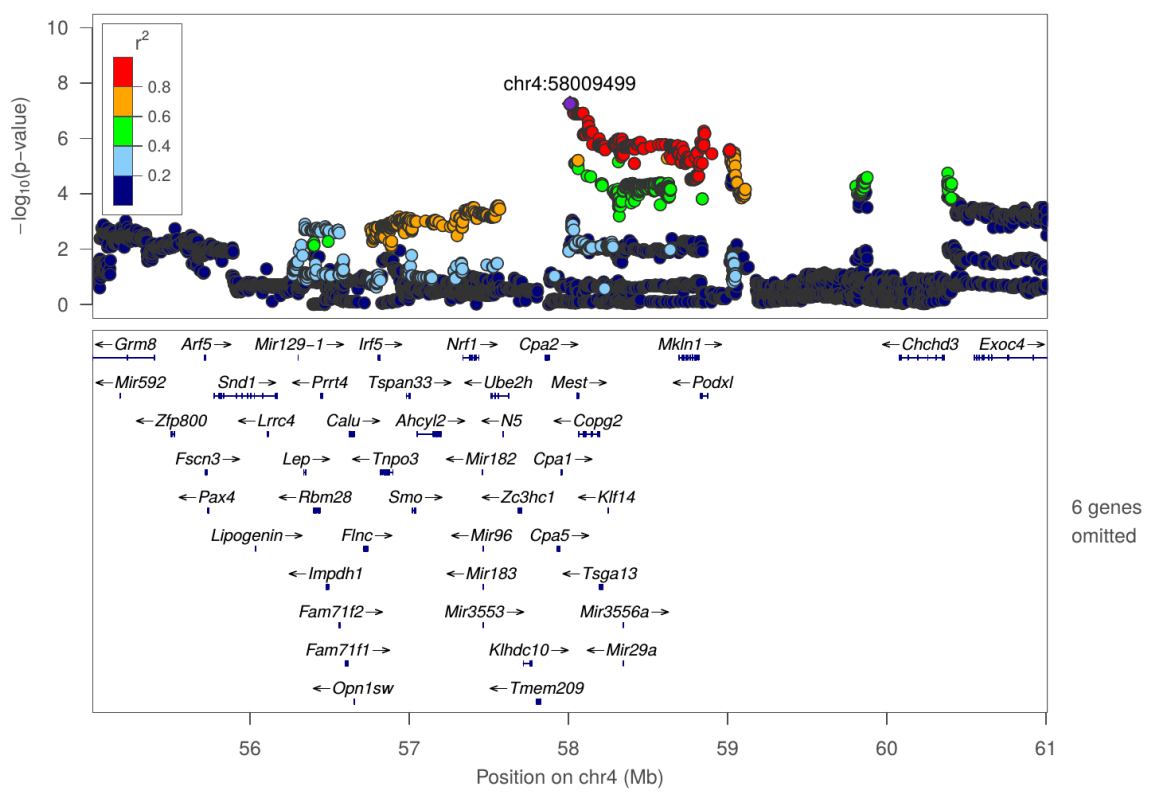

Figure S27: Regional association plot for OFT: Total distance to center zone at chr4:58009499 
bioRxiv preprint doi: https://doi.org/10.1101/2021.10.18.464872; this version posted October 19, 2021. The copyright holder for this preprint (which was not certified by peer review) is the author/funder, who has granted bioRxiv a license to display the preprint in perpetuity. It is made available under aCC-BY 4.0 International license.

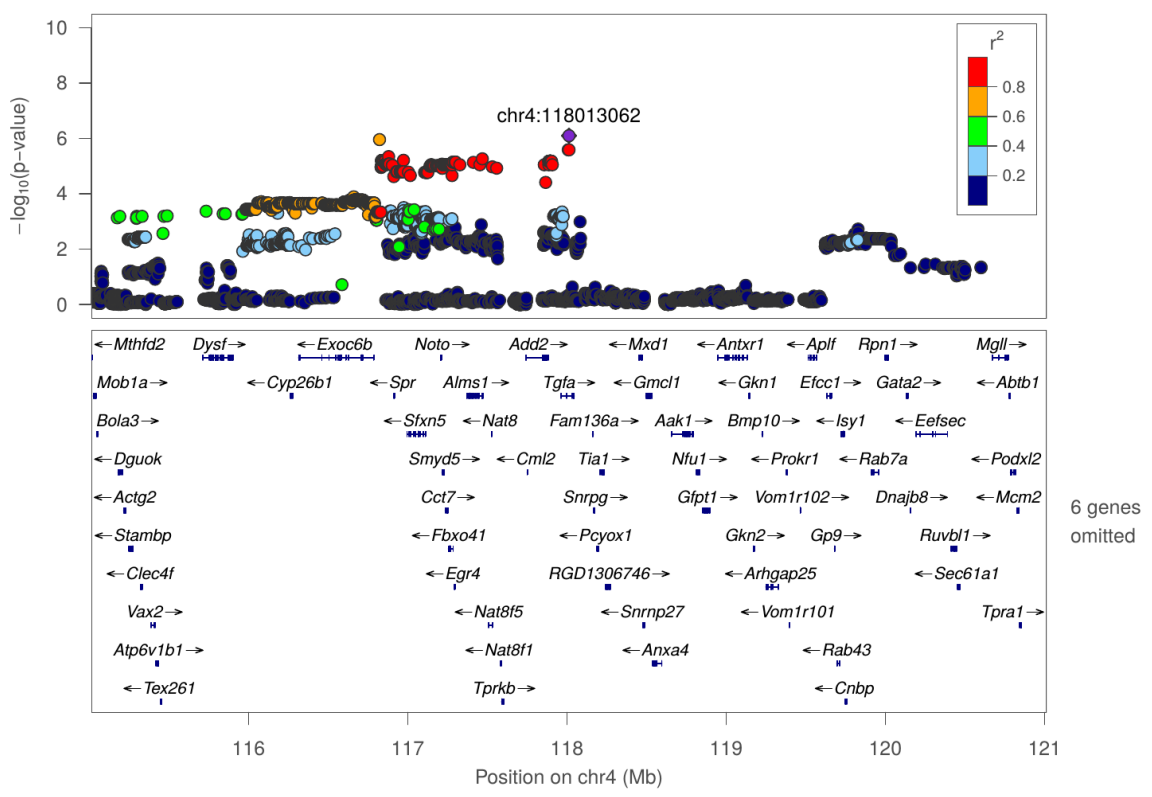

Figure S28: Regional association plot for OFT: Total distance to center zone at chr4:118013062 
bioRxiv preprint doi: https://doi.org/10.1101/2021.10.18.464872; this version posted October 19,2021 . The copyright holder for this preprint (which was not certified by peer review) is the author/funder, who has granted bioRxiv a license to display the preprint in perpetuity. It is made available under aCC-BY 4.0 International license.

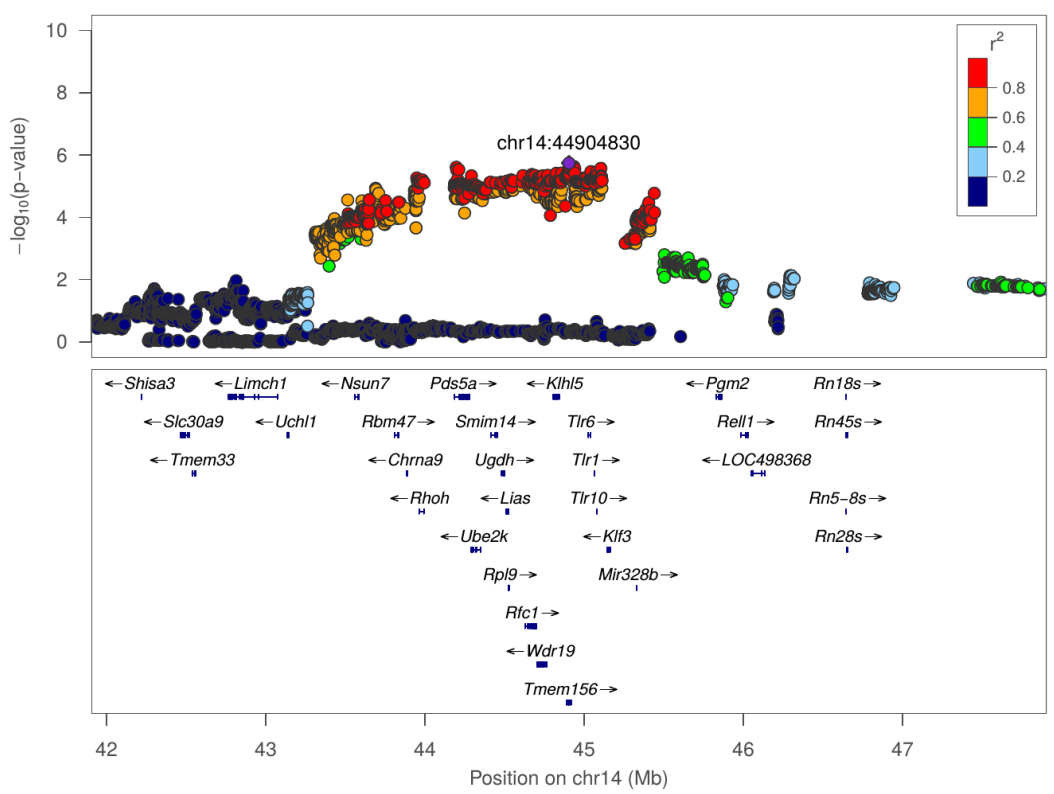

Figure S29: Regional association plot for OFT: Total distance to center zone at chr14:44904830 
bioRxiv preprint doi: https://doi.org/10.1101/2021.10.18.464872; this version posted October 19, 2021. The copyright holder for this preprint (which was not certified by peer review) is the author/funder, who has granted bioRxiv a license to display the preprint in perpetuity. It is made available under aCC-BY 4.0 International license.

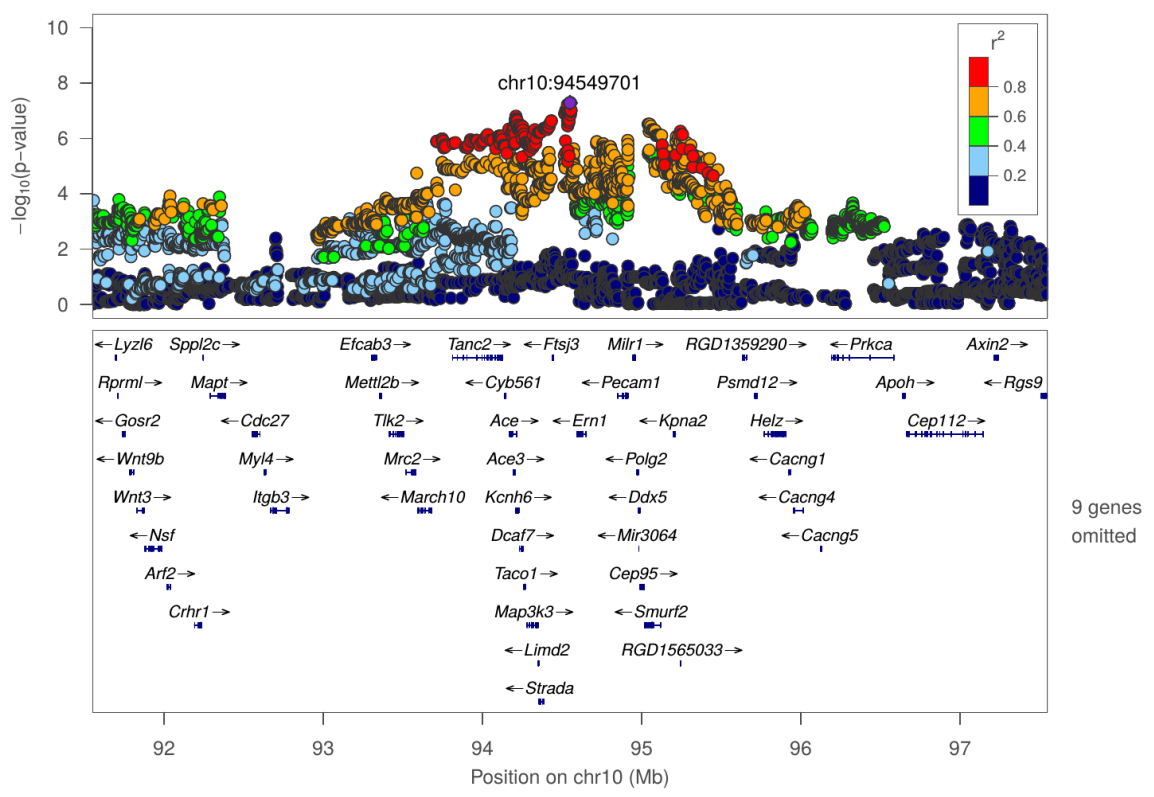

Figure S30: Regional association plot for OFT: Total travel distance at chr10:94549701 
bioRxiv preprint doi: https://doi.org/10.1101/2021.10.18.464872; this version posted October 19, 2021. The copyright holder for this preprint (which was not certified by peer review) is the author/funder, who has granted bioRxiv a license to display the preprint in perpetuity. It is made available under aCC-BY 4.0 International license.

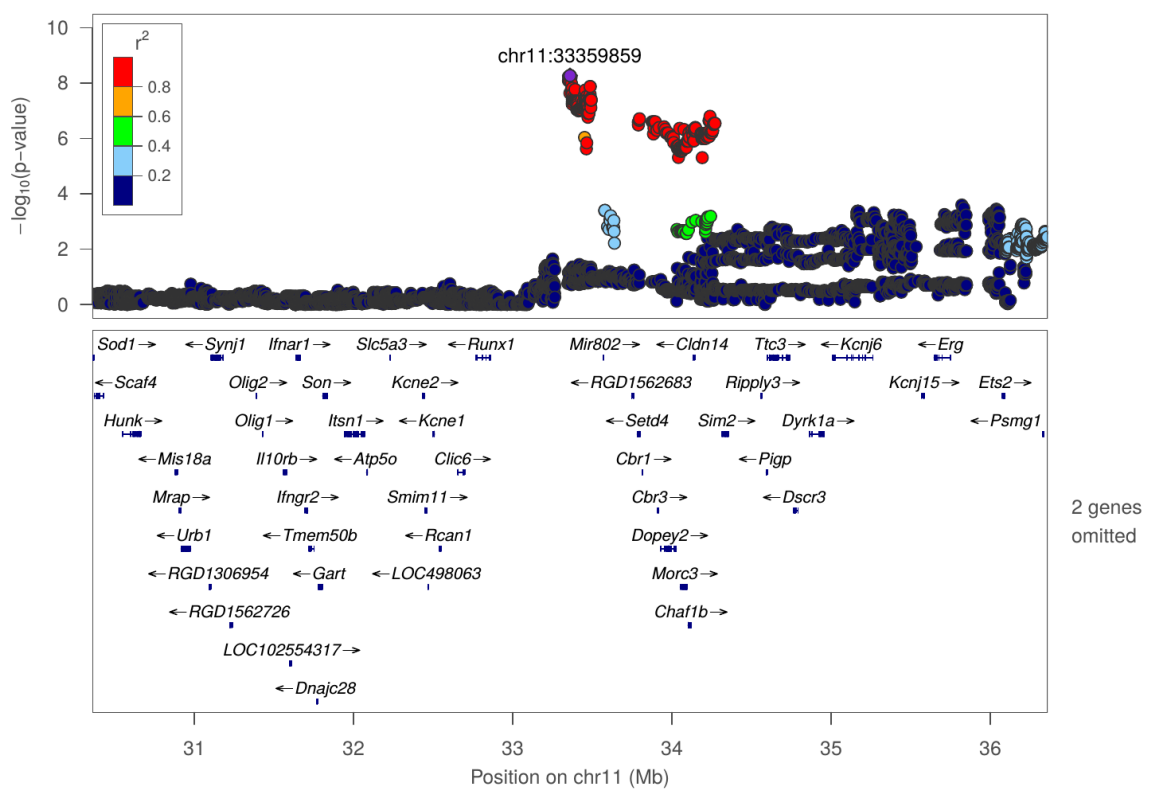

Figure S31: Regional association plot for OFT: Total travel distance at chr11:33359859 
bioRxiv preprint doi: https://doi.org/10.1101/2021.10.18.464872; this version posted October 19,2021 . The copyright holder for this preprint (which was not certified by peer review) is the author/funder, who has granted bioRxiv a license to display the preprint in perpetuity. It is made available under aCC-BY 4.0 International license.

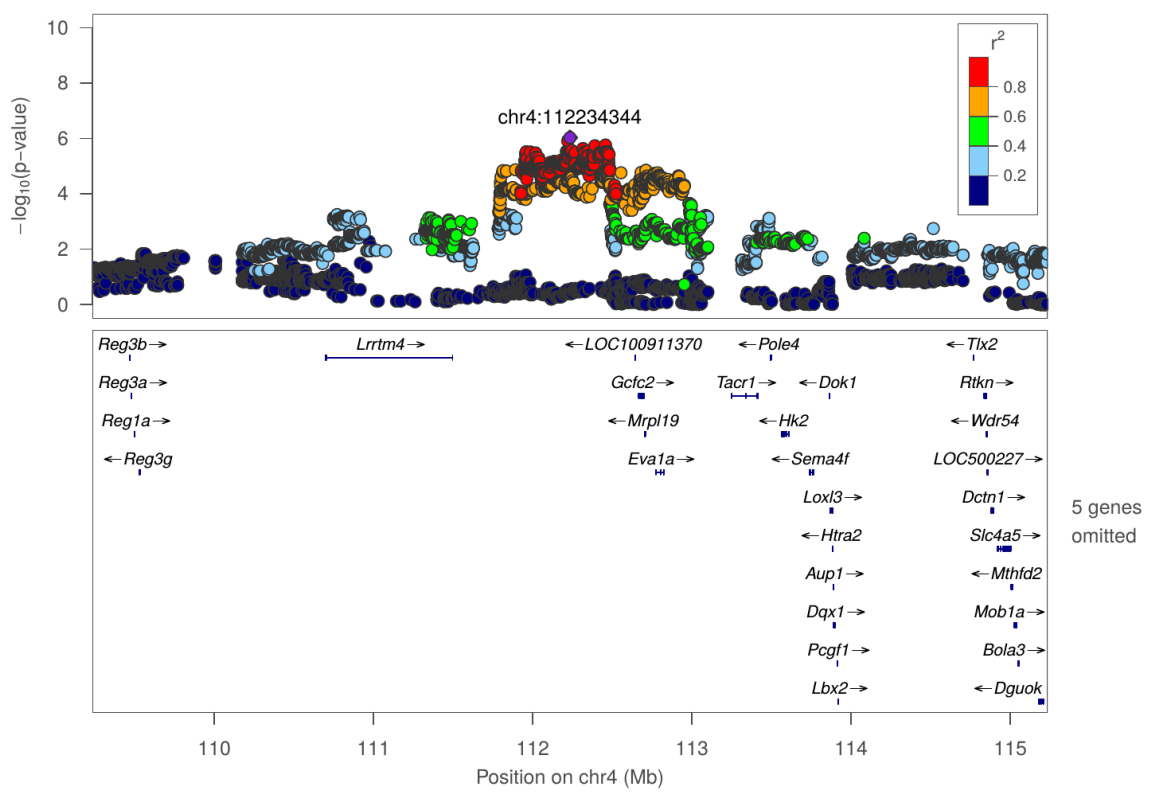

Figure S32: Regional association plot for NOIT: Duration in center zone at chr4:112234344 
bioRxiv preprint doi: https://doi.org/10.1101/2021.10.18.464872; this version posted October 19, 2021. The copyright holder for this preprint (which was not certified by peer review) is the author/funder, who has granted bioRxiv a license to display the preprint in perpetuity. It is made available under aCC-BY 4.0 International license.

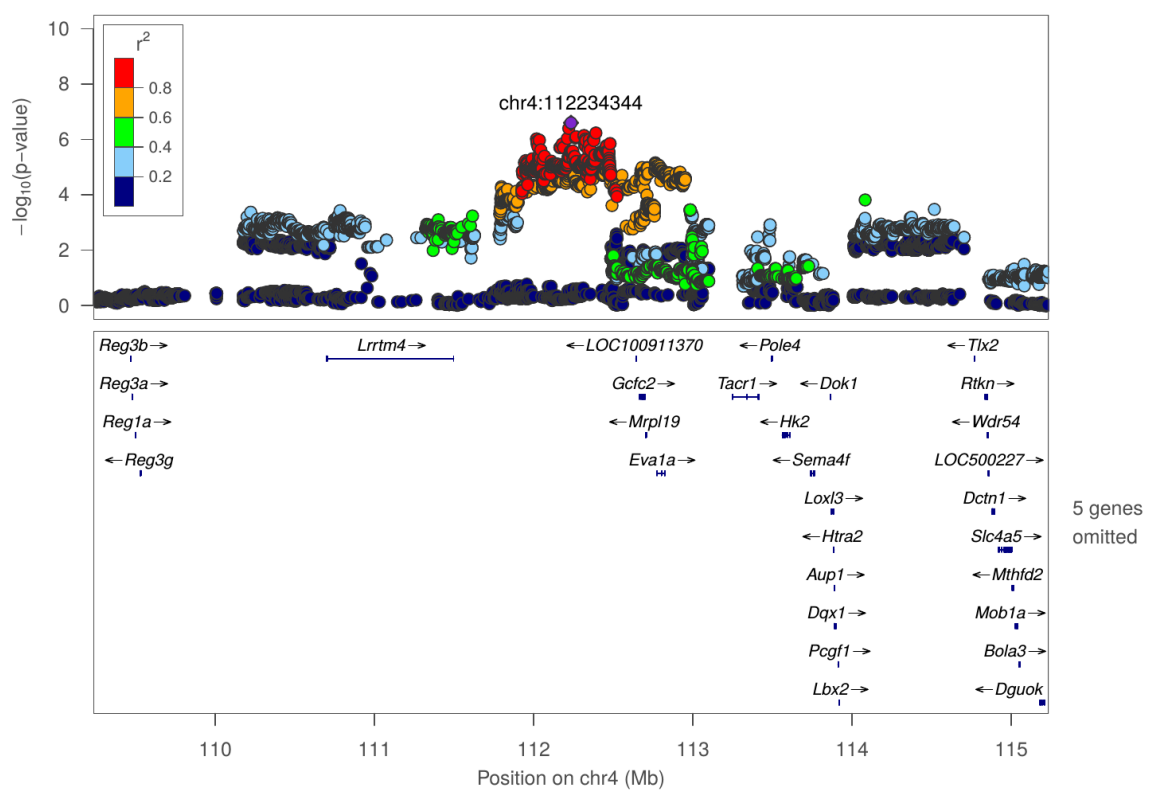

Figure S33: Regional association plot for NOIT: Mean distance to center zone at chr4:112234344 
bioRxiv preprint doi: https://doi.org/10.1101/2021.10.18.464872; this version posted October 19, 2021. The copyright holder for this preprint (which was not certified by peer review) is the author/funder, who has granted bioRxiv a license to display the preprint in perpetuity. It is made available under aCC-BY 4.0 International license.

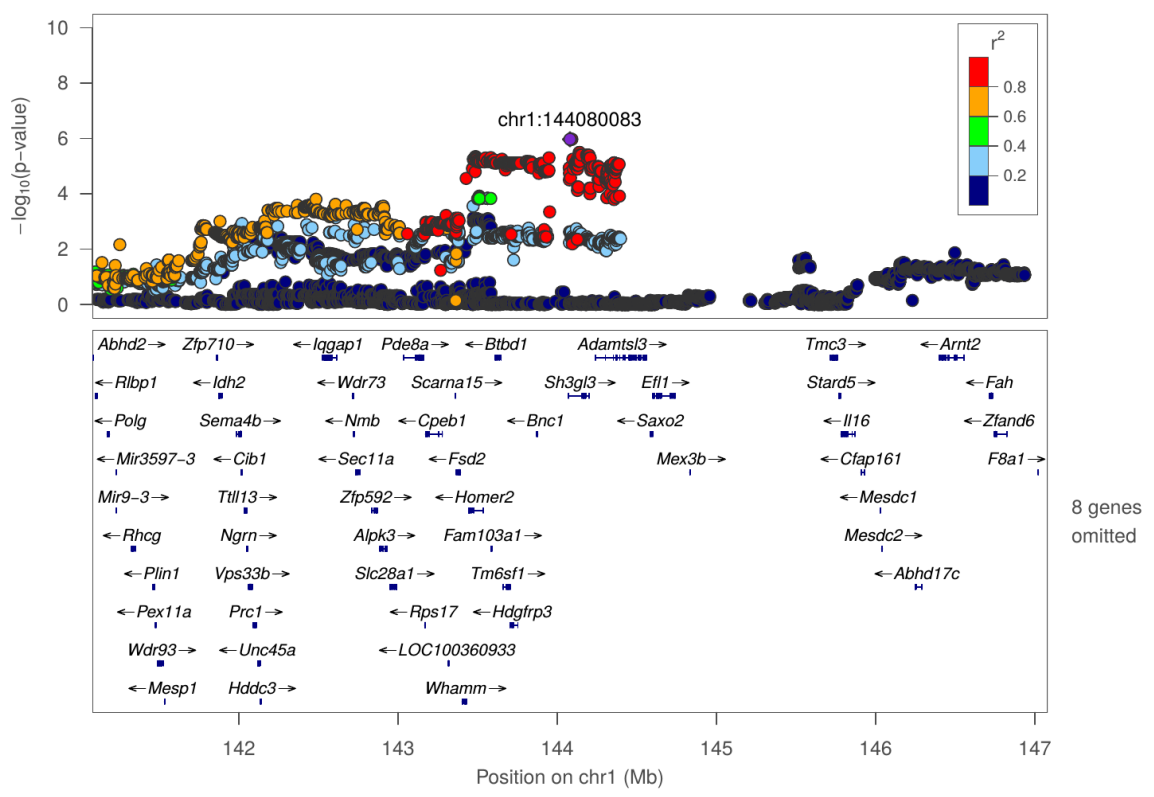

Figure S34: Regional association plot for NOIT: Total distance to center zone at chr1:144080083 
bioRxiv preprint doi: https://doi.org/10.1101/2021.10.18.464872; this version posted October 19,2021 . The copyright holder for this preprint (which was not certified by peer review) is the author/funder, who has granted bioRxiv a license to display the preprint in perpetuity. It is made available under aCC-BY 4.0 International license.

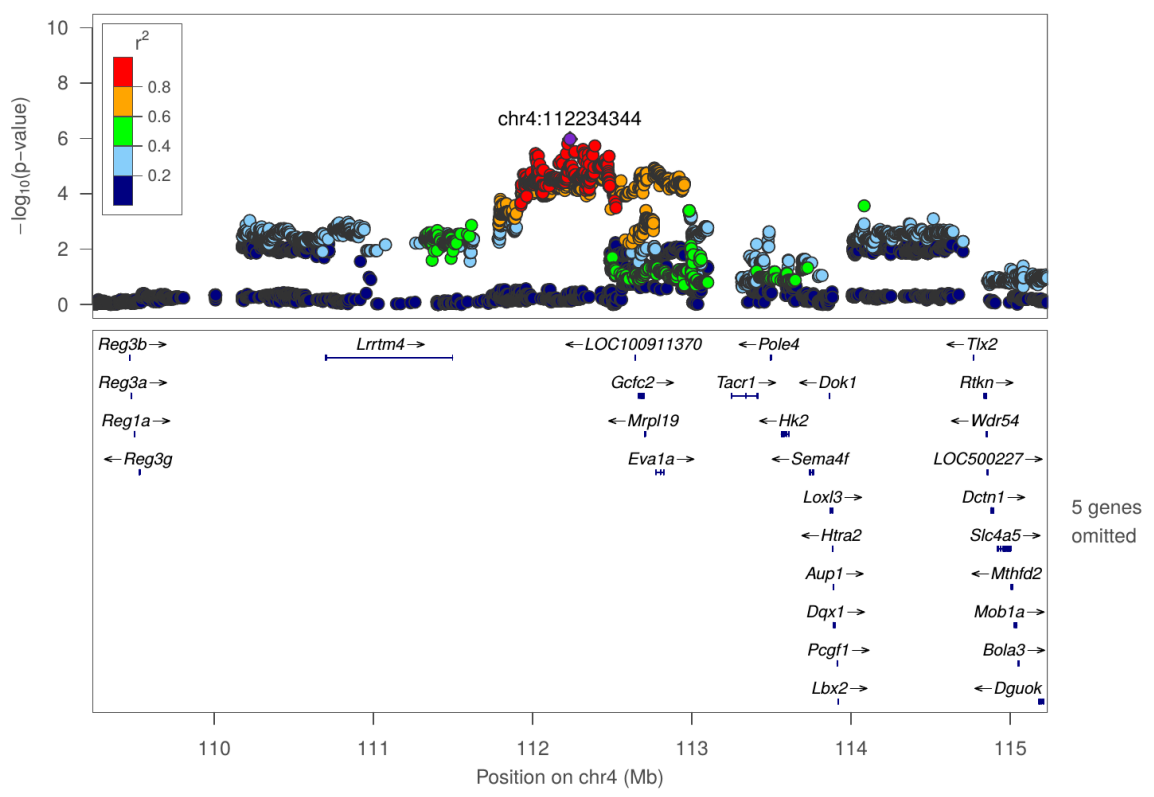

Figure S35: Regional association plot for NOIT: Total distance to center zone at chr4:112234344 
bioRxiv preprint doi: https://doi.org/10.1101/2021.10.18.464872; this version posted October 19, 2021. The copyright holder for this preprint (which was not certified by peer review) is the author/funder, who has granted bioRxiv a license to display the preprint in perpetuity. It is made available under aCC-BY 4.0 International license.

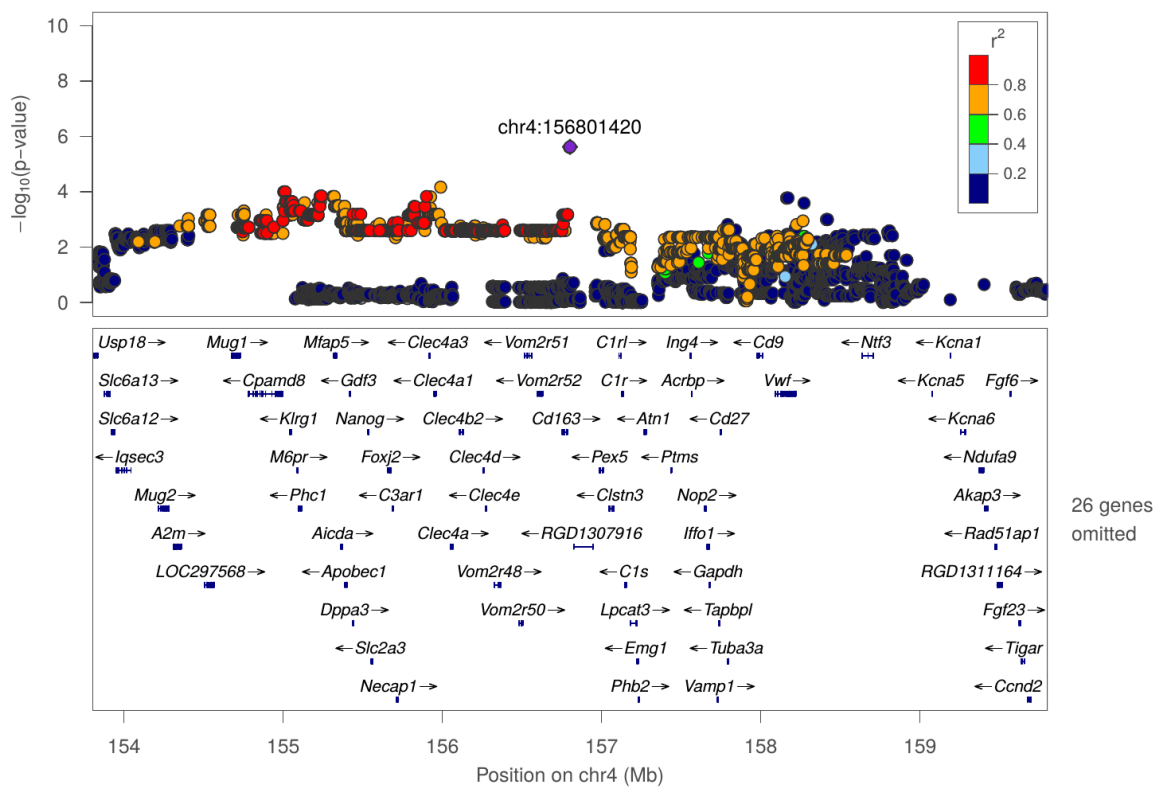

Figure S36: Regional association plot for NOIT: Total distance to center zone at chr4:156801420 
bioRxiv preprint doi: https://doi.org/10.1101/2021.10.18.464872; this version posted October 19,2021 . The copyright holder for this preprint (which was not certified by peer review) is the author/funder, who has granted bioRxiv a license to display the preprint in perpetuity. It is made available under aCC-BY 4.0 International license.

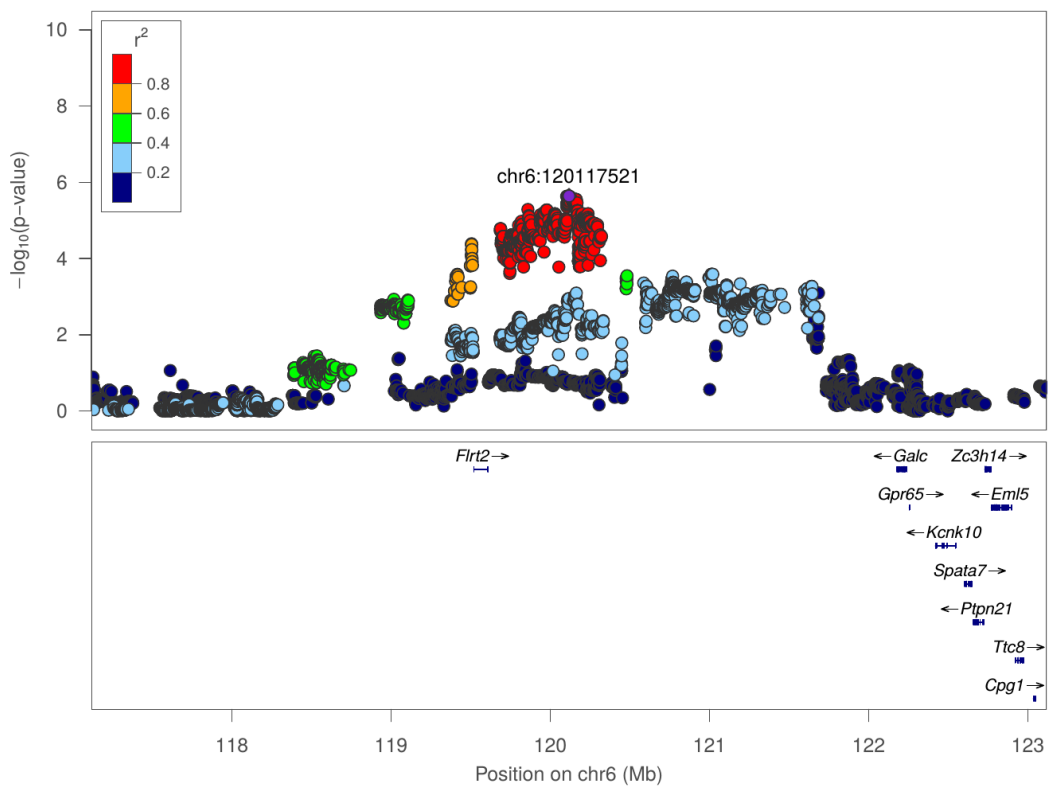

Figure S37: Regional association plot for NOIT: Total travel distance at chr6:120117521 
bioRxiv preprint doi: https://doi.org/10.1101/2021.10.18.464872; this version posted October 19, 2021. The copyright holder for this preprint (which was not certified by peer review) is the author/funder, who has granted bioRxiv a license to display the preprint in perpetuity. It is made available under aCC-BY 4.0 International license.

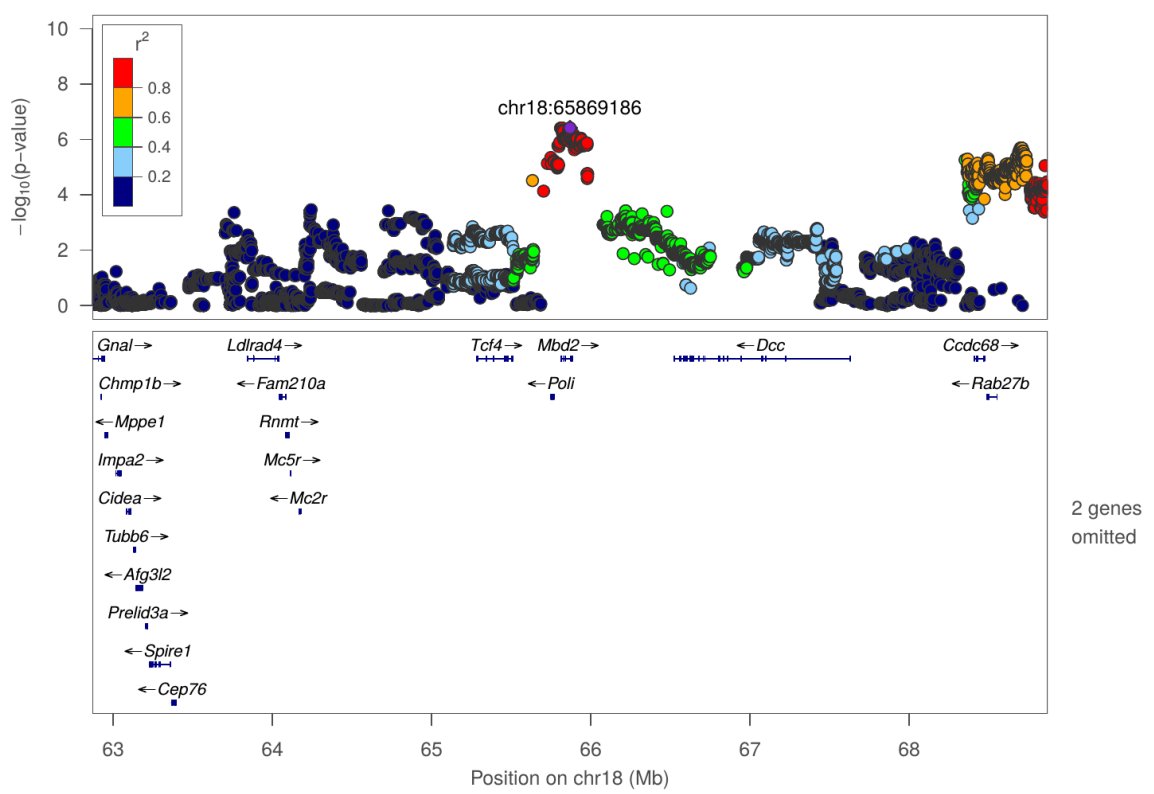

Figure S38: Regional association plot for SIT: Duration in object zone at chr18:65869186 
bioRxiv preprint doi: https://doi.org/10.1101/2021.10.18.464872; this version posted October 19,2021 . The copyright holder for this preprint (which was not certified by peer review) is the author/funder, who has granted bioRxiv a license to display the preprint in perpetuity. It is made available under aCC-BY 4.0 International license.

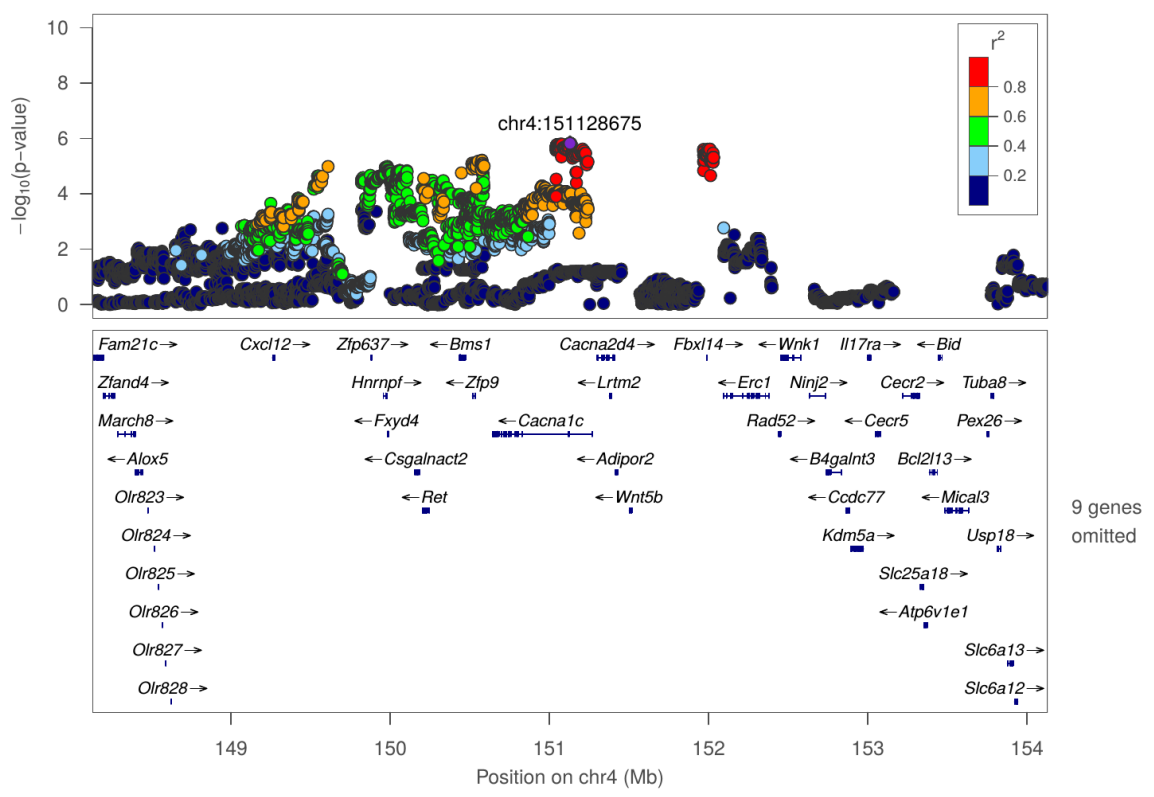

Figure S39: Regional association plot for SIT: Duration in social zone at chr4:151128675 
bioRxiv preprint doi: https://doi.org/10.1101/2021.10.18.464872; this version posted October 19,2021 . The copyright holder for this preprint (which was not certified by peer review) is the author/funder, who has granted bioRxiv a license to display the preprint in perpetuity. It is made available under aCC-BY 4.0 International license.

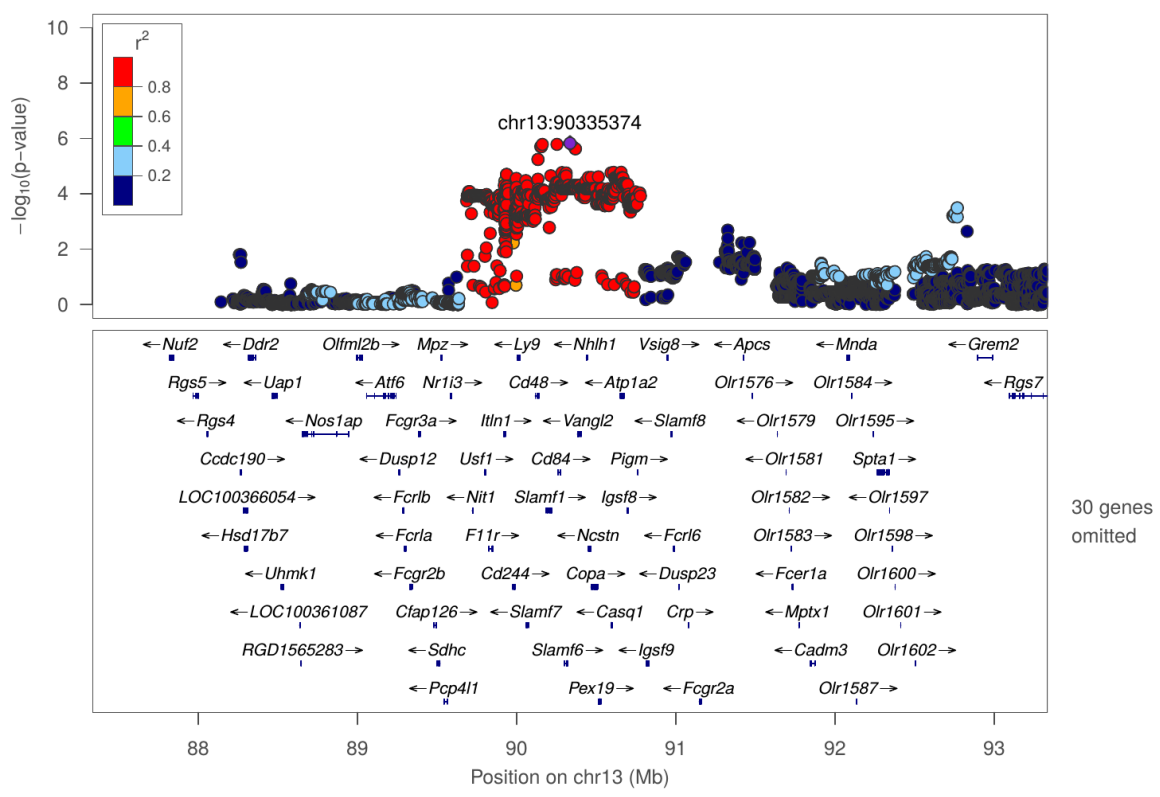

Figure S40: Regional association plot for SIT: Frequency of entering object zone at chr13:90335374 
bioRxiv preprint doi: https://doi.org/10.1101/2021.10.18.464872; this version posted October 19,2021 . The copyright holder for this preprint (which was not certified by peer review) is the author/funder, who has granted bioRxiv a license to display the preprint in perpetuity. It is made available under aCC-BY 4.0 International license.

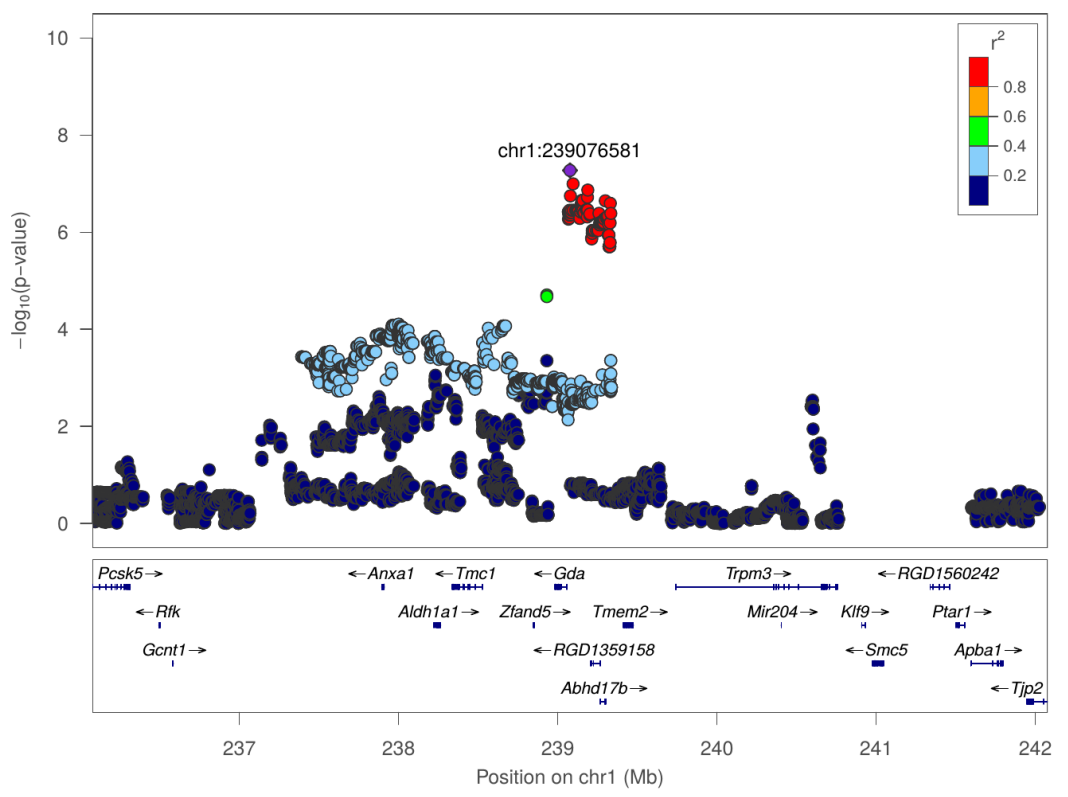

Figure S41: Regional association plot for SIT: Frequency of entering social zone at chr1:239076581 
bioRxiv preprint doi: https://doi.org/10.1101/2021.10.18.464872; this version posted October 19,2021 . The copyright holder for this preprint (which was not certified by peer review) is the author/funder, who has granted bioRxiv a license to display the preprint in perpetuity. It is made available under aCC-BY 4.0 International license.

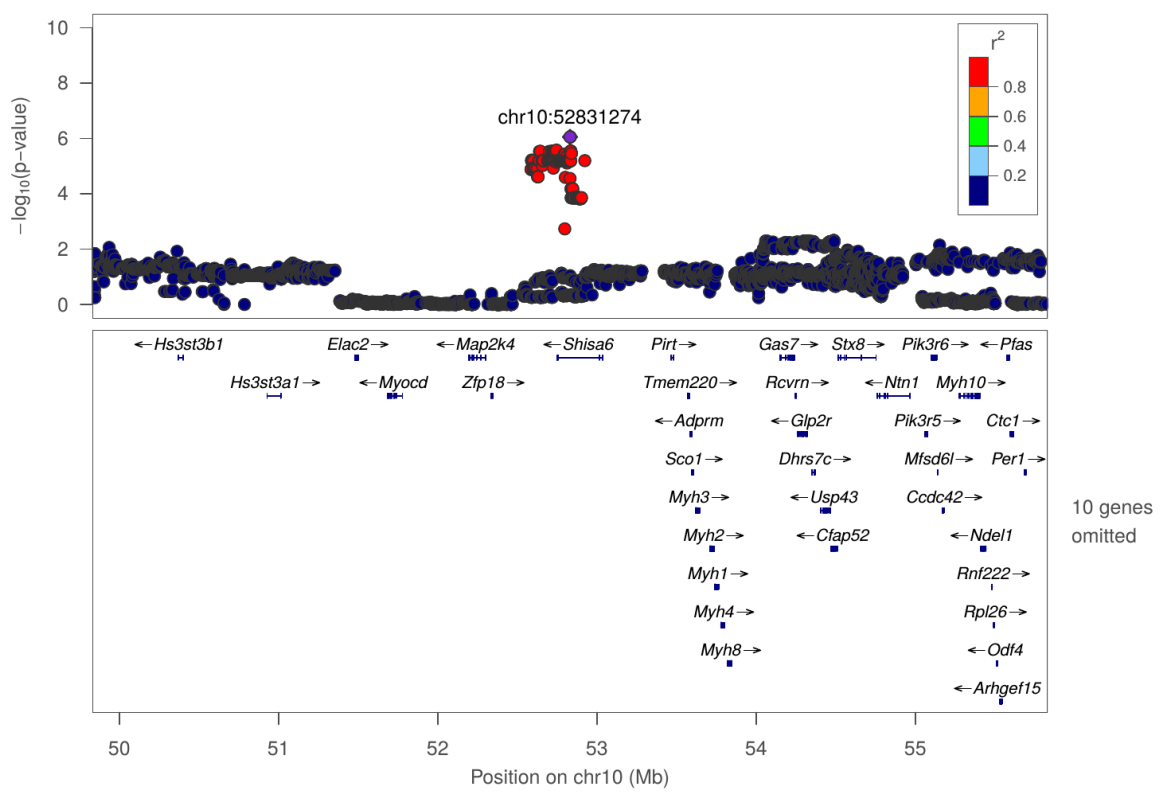

Figure S42: Regional association plot for SIT: Latency of entering social zone at chr10:52831274 
bioRxiv preprint doi: https://doi.org/10.1101/2021.10.18.464872; this version posted October 19,2021 . The copyright holder for this preprint (which was not certified by peer review) is the author/funder, who has granted bioRxiv a license to display the preprint in perpetuity. It is made available under aCC-BY 4.0 International license.

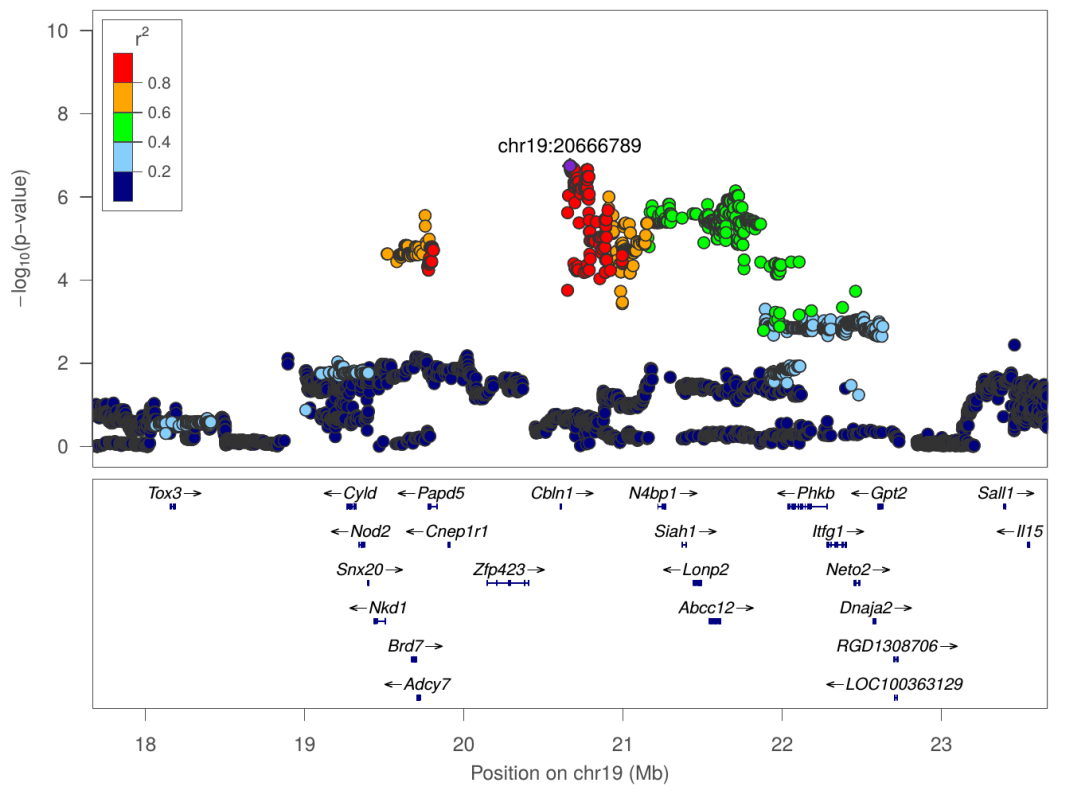

Figure S43: Regional association plot for SIT: Mean distance to object zone at chr19:20666789 
bioRxiv preprint doi: https://doi.org/10.1101/2021.10.18.464872; this version posted October 19, 2021. The copyright holder for this preprint (which was not certified by peer review) is the author/funder, who has granted bioRxiv a license to display the preprint in perpetuity. It is made available under aCC-BY 4.0 International license.

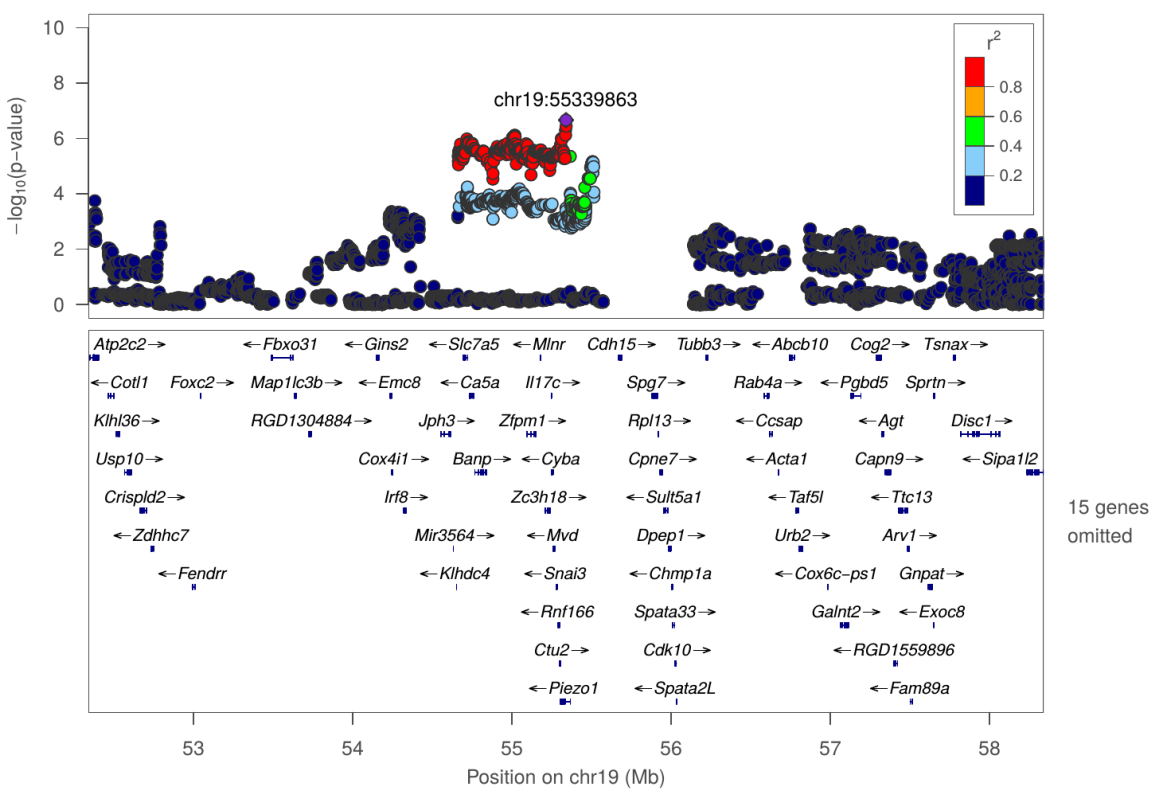

Figure S44: Regional association plot for SIT: Mean distance to social zone at chr19:55339863 
bioRxiv preprint doi: https://doi.org/10.1101/2021.10.18.464872; this version posted October 19,2021 . The copyright holder for this preprint (which was not certified by peer review) is the author/funder, who has granted bioRxiv a license to display the preprint in perpetuity. It is made available under aCC-BY 4.0 International license.

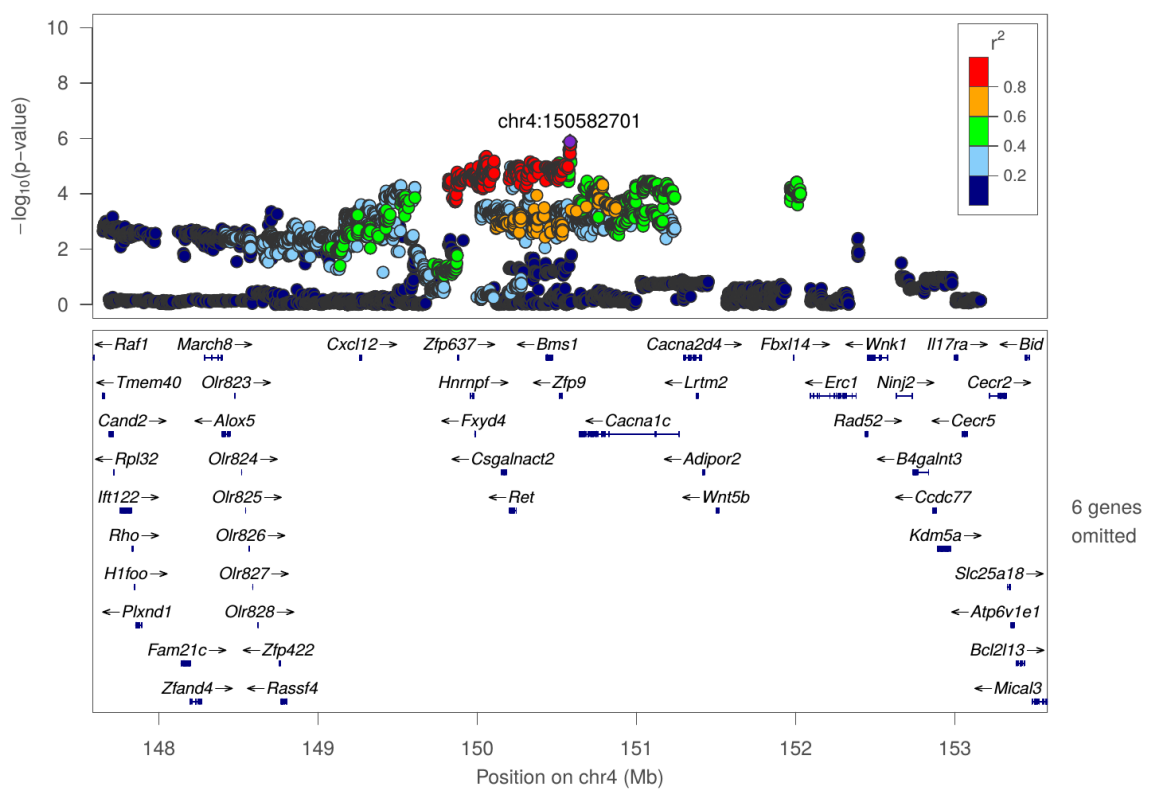

Figure S45: Regional association plot for SIT: Mean distance to social zone at chr4:150582701 
bioRxiv preprint doi: https://doi.org/10.1101/2021.10.18.464872; this version posted October 19,2021 . The copyright holder for this preprint (which was not certified by peer review) is the author/funder, who has granted bioRxiv a license to display the preprint in perpetuity. It is made available under aCC-BY 4.0 International license.

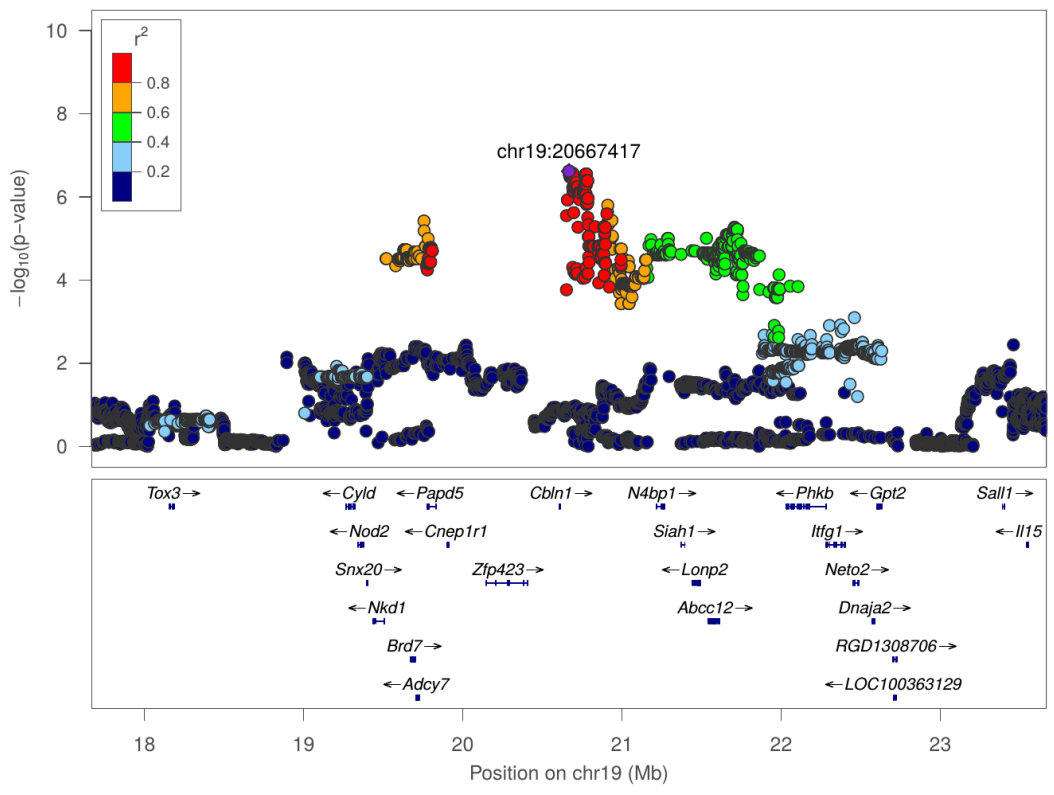

Figure S46: Regional association plot for SIT: Total distance to object zone at chr19:20667417 
bioRxiv preprint doi: https://doi.org/10.1101/2021.10.18.464872; this version posted October 19, 2021. The copyright holder for this preprint (which was not certified by peer review) is the author/funder, who has granted bioRxiv a license to display the preprint in perpetuity. It is made available under aCC-BY 4.0 International license.

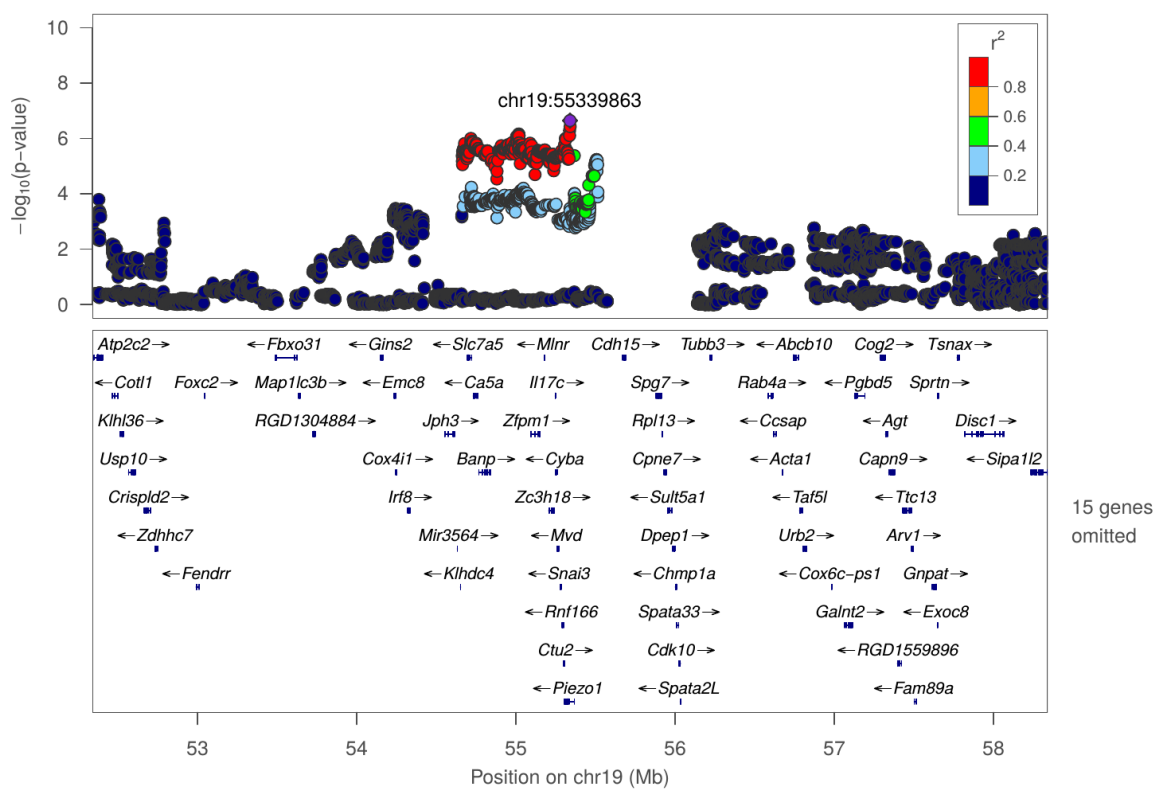

Figure S47: Regional association plot for SIT: Total distance to social zone at chr19:55339863 
bioRxiv preprint doi: https://doi.org/10.1101/2021.10.18.464872; this version posted October 19,2021 . The copyright holder for this preprint (which was not certified by peer review) is the author/funder, who has granted bioRxiv a license to display the preprint in perpetuity. It is made available under aCC-BY 4.0 International license.

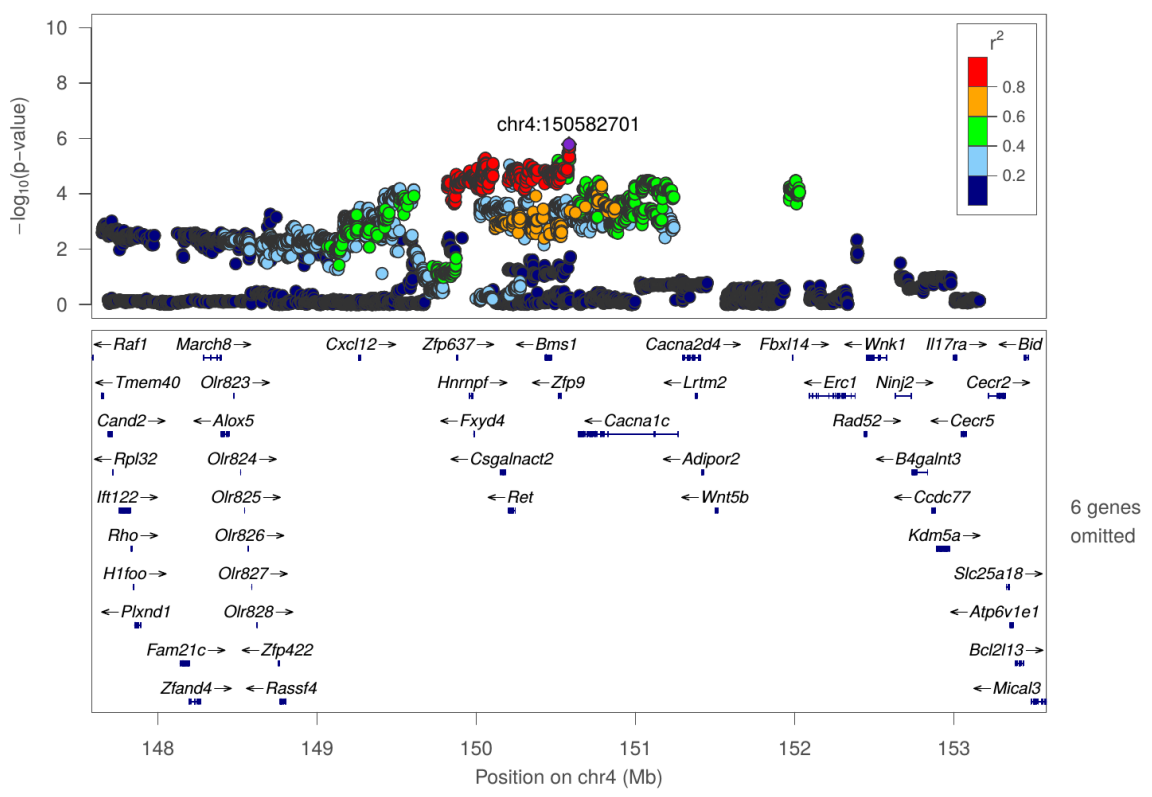

Figure S48: Regional association plot for SIT: Total distance to social zone at chr4:150582701 
bioRxiv preprint doi: https://doi.org/10.1101/2021.10.18.464872; this version posted October 19,2021 . The copyright holder for this preprint (which was not certified by peer review) is the author/funder, who has granted bioRxiv a license to display the preprint in perpetuity. It is made available under aCC-BY 4.0 International license.

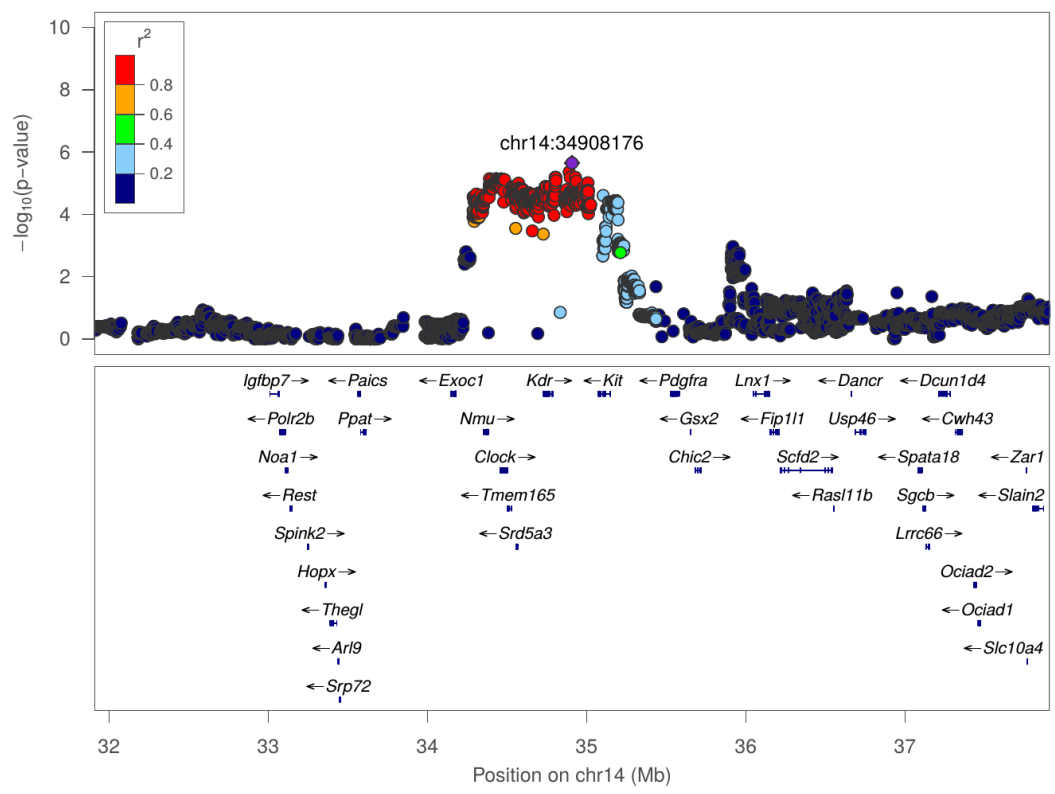

Figure S49: Regional association plot for SIT: Total travel distance at chr14:34908176 
bioRxiv preprint doi: https://doi.org/10.1101/2021.10.18.464872; this version posted October 19,2021 . The copyright holder for this preprint (which was not certified by peer review) is the author/funder, who has granted bioRxiv a license to display the preprint in perpetuity. It is made available under aCC-BY 4.0 International license.

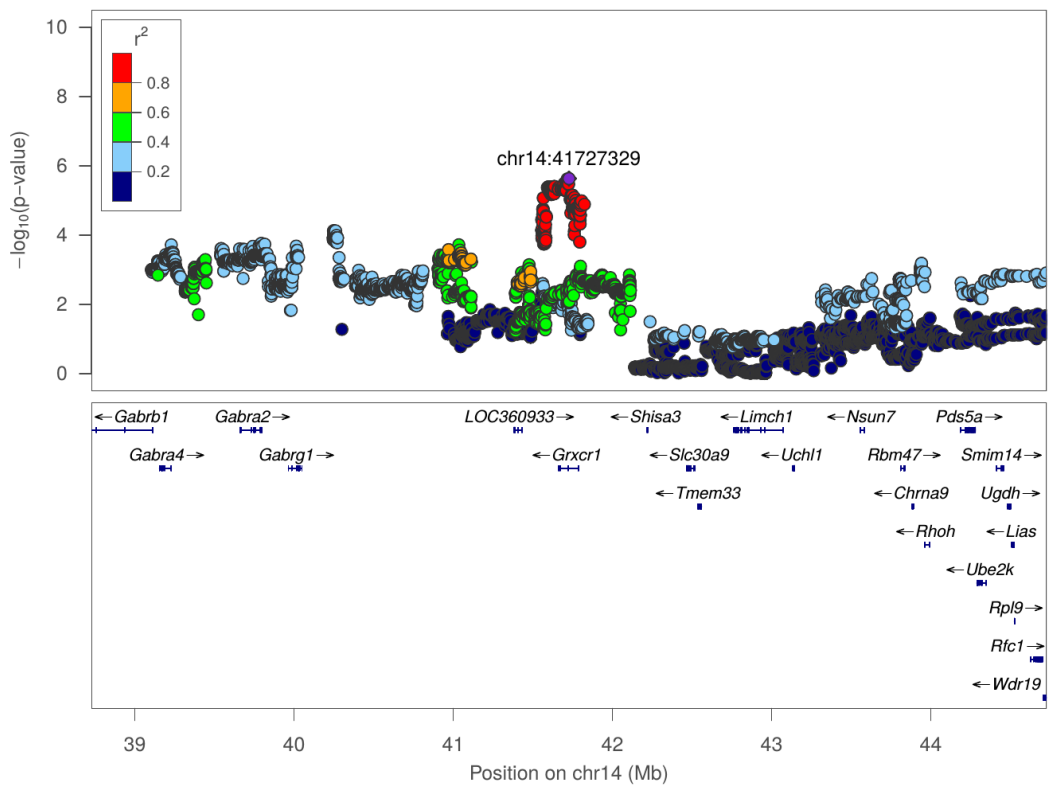

Figure S50: Regional association plot for SIT: Total travel distance at chr14:41727329 